Portland State University

PDXScholar

\title{
Can a Three-Day Training Focusing on the Nature of Science and Science Practices as They Relate to Mind in the Making Make a Difference in Preschool Teachers' Self-Efficacy Engaging in Science Education?
}

Colleen Meacham

Portland State University

Follow this and additional works at: https://pdxscholar.library.pdx.edu/open_access_etds

Part of the Early Childhood Education Commons, Pre-Elementary, Early Childhood, Kindergarten Teacher Education Commons, and the Science and Mathematics Education Commons Let us know how access to this document benefits you.

\section{Recommended Citation}

Meacham, Colleen, "Can a Three-Day Training Focusing on the Nature of Science and Science Practices as They Relate to Mind in the Making Make a Difference in Preschool Teachers' Self-Efficacy Engaging in Science Education?" (2017). Dissertations and Theses. Paper 4076.

https://doi.org/10.15760/etd.5960

This Thesis is brought to you for free and open access. It has been accepted for inclusion in Dissertations and Theses by an authorized administrator of PDXScholar. Please contact us if we can make this document more accessible: pdxscholar@pdx.edu. 
Can a Three-Day Training Focusing on the Nature of Science and Science Practices as They Relate to Mind in the Making

Make a Difference in Preschool Teachers' Self-Efficacy

Engaging in Science Education?

by

Colleen Meacham

A thesis submitted in partial fulfillment of the

requirements for the degree of

\author{
Master of Science in Teaching \\ in \\ General Science \\ Thesis Committee: \\ William Becker, Chair \\ Stephanie Wagner \\ Ingrid Anderson
}

Portland State University

2017 


\begin{abstract}
As technology and our world understanding develop, we will need citizens who are able to ask and answer questions that have not been thought of yet. Currently, high school and college graduates entering the workforce demonstrate a gap in their ability to develop unique solutions and fill the current technology-driven jobs. To address this gap, science needs to be prioritized early in children's lives. The focus of this research was to analyze a science training program that would help pre-school teachers better understand Mind in the Making life skills, the nature of science, science practices, and improve their self-efficacy integrating science education into their classrooms and curriculum. Seventy-one teachers enrolled in two three-day, professional development trainings that were conducted over three, five-hour sessions approximately one month apart...

During that training the teachers learned hands-on activities for young children that introduced life and physical science content. They were also given the task of developing and implementing a science-based lesson for their students and then analyzing it with other participants

The information from the lesson plans was collected for analysis. After the last training the teachers were given a pre/post retrospective survey to measure effective outcomes. The results from the lesson plans and surveys indicate that the trainings helped improve the teachers' understanding of Mind in the Making, the nature of science, and science practices. The results also show that the teachers felt more comfortable integrating science education into their classrooms and curriculum.
\end{abstract}




\section{Dedication}

This research and thesis is dedicated to my family who supported me and to the children now and in the future. Let us answer the questions that have not been thought of yet. 


\section{Acknowledgements}

I wish to thank my faculty advisor, Stephanie Wagner. Thank you to the other members of the Center of Science Education: Bill Becker, Siobhan McDonald, Christina Trecha, Susan Holveck, and Susan Duncan. I want to extend my appreciation to my classmates who supported me in developing my research and writing my paper, Noelle Frances Garcia Niedo, Leah Plack, Ciarra Greene, Kayla Jury, Alexia Robles and Ben Webber. The programs that supported my trainings: Friends of Tryon Creek State Park, Oregon Museum of Science and Industry, Head Start, Portland State University, and Child Care Resource and Referral have my gratitude. To my family, with all my heart, thank you for your support and love throughout the course of my research. 


\section{Table of Contents}

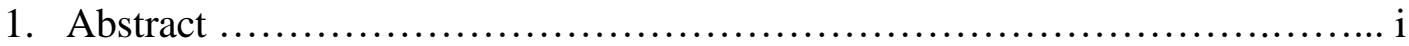

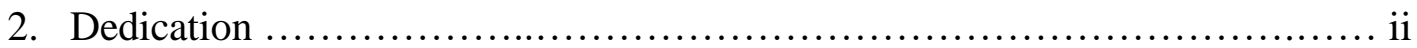

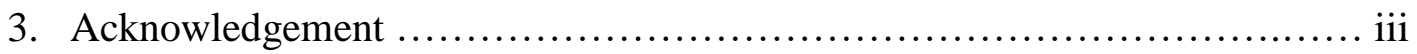

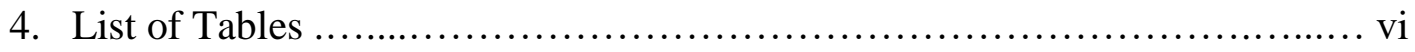

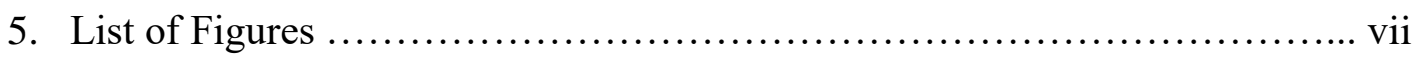

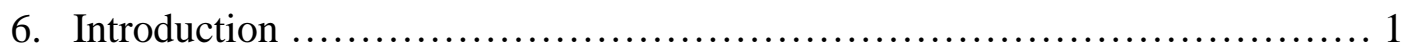



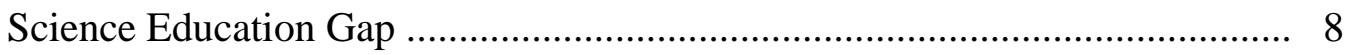

Preschool Science Education .................................................. 9

Preschool Teacher Professional Development .............................. 11

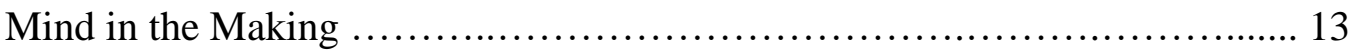

Nature of Science and Science Practices ..................................... 14

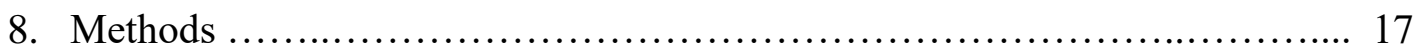

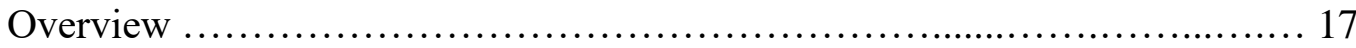

Program and Locations ....................................................... 18

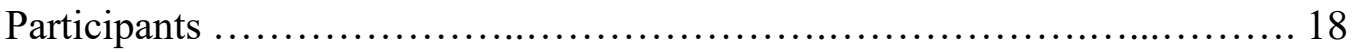

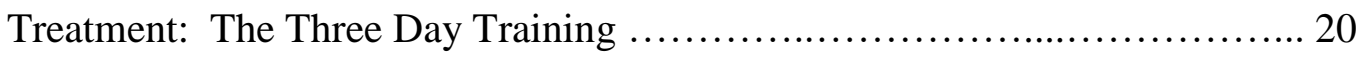

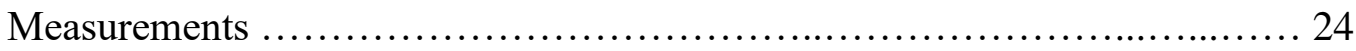

Work Sample - Lesson Plan ....................................... 24

Pre/Post Retrospective Survey and Analysis .......................... 25

Data Analysis ................................................... 26

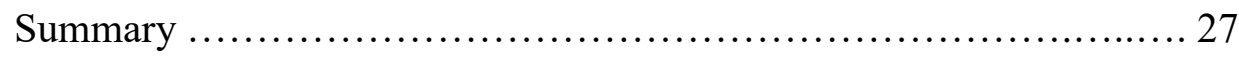



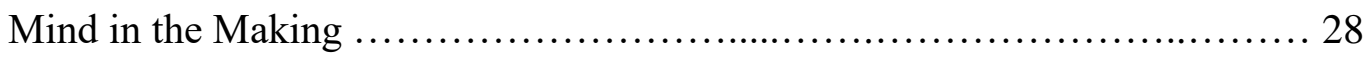

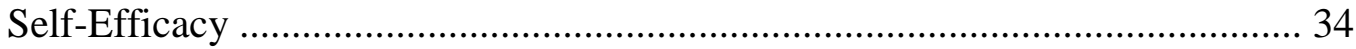

Understanding of the Nature of Science and Science Inquiry .................. 46

Student Lesson Plans .................................................... 57

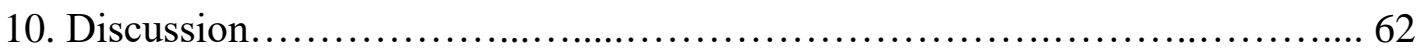

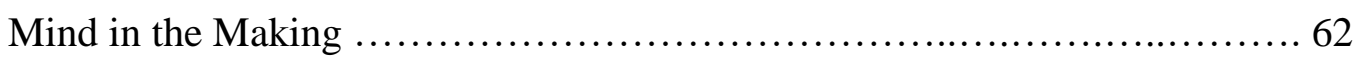

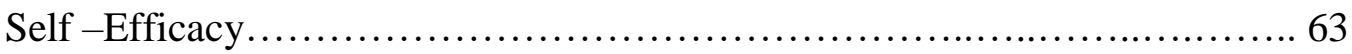

Understanding of the Nature of Science and Science Inquiry ...................... 64

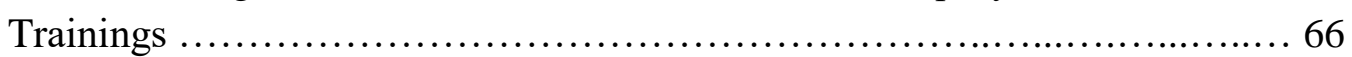

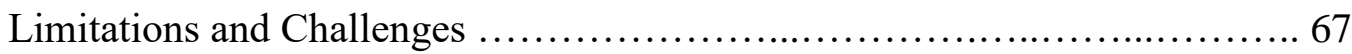

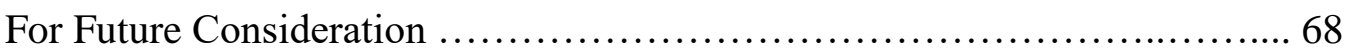

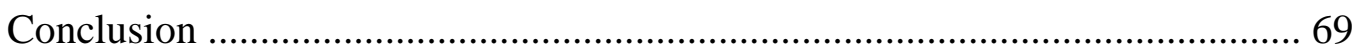

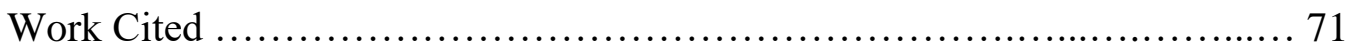

Appendix A - Table of Pre-Teaching Programs in Oregon ....................... 73

Appendix B -Mind in the Making as related to the NOS and Science Practices74 Appendix C - Lesson Plan Template ................................................................ 75 
Appendix D - Lesson Plan Rubric

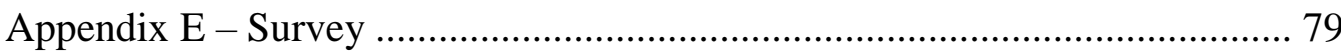

Appendix F - Survey Rubric .................................................................... 82 
Table \# $\underline{\text { Table Title }}$

\section{List of Tables}

1. Teacher Education Level 19

$\begin{array}{ll}\text { 2. Teaching Experience } & 19\end{array}$

3. Teacher Gender 19

4. Teacher Age Range 19

5. First Day of Training 21

6. Second Day of Training 22

7. Third Day of Training 23

8. I believe science inquiry promotes critical thinking in students 30

9. I believe the nature of science includes student problem solving 31

10. I can adjust my lessons to the appropriate level for individual students statistical analysis.

11. Even when I try very hard, I don't teach science as well as I do most other subjects statistical analysis.

12. I am not very effective in teaching/leading hands-on science projects statistical analysis.

13. I understand science concepts well enough to be effective in teaching science statistical analysis.

14. I am typically able to help students answer their own questions in science statistical analysis.

15. When teaching science, I welcome student questions statistical analysis.

16. I have the necessary skills to teach hands-on/inquiry-based science statistical analysis.

17. I believe all students should get the same results... statistical analysis.

18. I believe scientific theories can change based on new evidence.

19. I believe it is my job to foster student problem solving statistical analysis.

20. When I encounter a new phenomenon, I know how to use the nature of science and science inquiry... statistical analysis.

21. I can use simple everyday items to teach science statistical analysis. 54

22. I believe there is only one best way to teach science statistical analysis. 


\section{List of Figures}

Figure \# Figure Title $\quad \underline{\text { Page }}$

1a I believe science inquiry promotes critical thinking in students 29

1b I believe science inquiry promotes critical thinking in students 30

2a I believe the nature of science includes student problem solving. 31

$2 \mathrm{~b} \quad$ I believe the nature of science includes student problem solving. 32

3a I can adjust my lessons to the appropriate level for individual students. 33

$3 \mathrm{~b} \quad$ I can adjust my lessons to the appropriate level for individual students. $\quad 34$

4a Even when I try very hard, I don't teach science as well as I do most 36

4b Even when I try very hard, I don't teach science as well as I do most $\quad 37$ other subjects.

5a I am not very effective in teaching/leading hands-on science projects $\quad 38$

$5 \mathrm{~b} \quad$ I am not very effective in teaching/leading hands-on science projects 39

6a I understand science concepts well enough to be effective in teaching 40

6b I understand science concepts well enough to be effective in teaching $\quad 41$ science

7a I am typically able to help students answer their own questions in 42 science

7b I am typically able to help students answer their own questions in science

8a When teaching science, I welcome student questions 43

$8 \mathrm{~b} \quad$ When teaching science, I welcome student questions 44

9a I have the necessary skills to teach hands-on/inquiry-based science 45

$9 \mathrm{~b} \quad$ I have the necessary skills to teach hands-on/inquiry-based science 46

10a I believe all students should get the same results... 47

10b I believe all students should get the same results... 48

11a I believe scientific theories can change based on new evidence. 48

11b I believe scientific theories can change based on new evidence. 49

12a I believe it is my job to foster student problem solving. 50

$12 \mathrm{~b} \quad$ I believe it is my job to foster student problem solving.

13a When I encounter a new phenomenon, I know how to use the nature 52 of science ...

13b When I encounter a new phenomenon, I know how to use the nature 53 of science ...

14a I can use simple everyday items to teach science. 54

14b I can use simple everyday items to teach science.

15a I believe there is only one best way to teach science. 55

$15 \mathrm{~b} \quad$ I believe there is only one best way to teach science. 56

16 Aspects of Lesson Plan 58

$17 \quad$ Science Practices 58

18 Mind in the Making $\quad 59$

19 Understanding Science $\quad 60$ 


\section{Introduction}

For over a decade United States corporations have been feeling the burden of not having enough qualified STEM (Science, Technology, Engineering, and Mathematics) employees. The days of graduating skilled workers for manual labor have long passed. Our workforce needs to be able to keep up with changes in technological and scientific understanding and adapt accordingly. In 2013, the U.S. Chamber of Commerce Foundation came out with a position paper emphasizing the importance of STEM education to corporate America (U.S. Chamber of Commerce Foundation, 2013). To address this issue, for the last ten years several major corporations (Exon, AT\&T, JP Morgan, Ford, Boeing, Verizon, Goldman Sachs, and Target) invested money, time and equipment in STEM education (Walker, 2016, Schiller \& Arena, 2012).

The gap in the number and diversity of people graduating with STEM degrees needs to be more deeply addressed. This gap starts early in students' educational careers and continues to grow as they head toward high school graduation (Morgan; Farkas; Hillimier; \& Maczuga, 2016). Morgan et al. (2016) did a longitudinal study of over 7000 students from kindergarten to eighth grade finding that starting in kindergarten there is evidence that different groups of children scored lower in general knowledge than others. Lower general knowledge scores in kindergarten indicate lower scores in first grade, which indicates lower science scores in third through eighth grade. Morgan et al. go on to say that children entering kindergarten less knowledgeable in natural and social sciences will continue to struggle in these areas throughout their educational career. Introduction to natural sciences can start as early as preschool, when children are naturally curious about the world around them, investigating and asking questions 
(Wilson, 2007).

The National Association for the Education of Young Children (NAEYC) and The National Science Teachers' Association (NSTA) have written position papers on the importance of encouraging preschoolers to engage in science (Bosse; Jacobs; \& Anderson, 2009 and National Science Teachers Association [NSTA], 2014). Several states, including Massachusetts, Colorado, California, Ohio, and Virginia, have started to integrate science standards into their preschool education requirements to address the need for more understanding of the sciences in society. Some states, for example Vermont, are working on aligning their preschool standards with Next Generation Science Standards (NGSS) (Vermont Agency of Education, 2015). The State of Oregon is basing their preschool science standards on those set out by the Office of Head Start.

The Head Start science standards are based on both a developmental progression and science inquiry skills. The Head Start Scientific Reasoning Domain is divided into three developmental levels: 36 to 48 months, 48 to 60 months, and by 60 months. Each developmental level has a developmental indicator. The domain itself is divided into two sub domains: Scientific Inquiry and Reasoning and Problem Solving. The sub domains are again divided in to goals: observe and describe, vocabulary, and compare and categorize for Scientific Inquiry and ask questions, gather information, and make predictions, plan and conduct investigations, and analyze and communicate results and draw conclusions for Reasoning and Problem Solving (Head Start, 2015).

However, in most preschool classrooms STEM is not emphasized (Brenneman; Stevenson-Boyd; \& Frede, 2009 and Maier; Greenfield; \& Bulotsky- Shearer, 2013). In most classrooms, once or twice per year there is a focus in science in the area of starting 
a garden, raising butterflies, or maybe watching the leaves change in the fall. But once the project is done there is not a follow up, expansion, or continuation of the study. There is also a limited physical area for science in early childhood classrooms. Science is often not extended into other areas in the classroom or subjects of study (Brenneman et al., 2009).

One of the leading factors for the limited emphasis on science is lack of opportunities for preschool teachers to learn about the nature of science and science inquiry (Andersson \& Gollburg, 2012). In a survey of the twenty-five colleges in Oregon that have undergraduate Early Childhood Education programs, only three of them have a science education component. Of the community colleges in this survey, six of them do not require the students to take a science class to earn their Associates of Applied Sciences degree (Appendix A).

Practicing teachers have limited opportunities to understand the importance of science education through professional development units. In the Portland Metro area, there are only two professional development classes given that address science education in the classroom and they are only given once per year. Without an opportunity to learn how to teach science in a developmentally appropriate way, how can preschool teachers successfully engage their students in this topic?

Developmentally appropriate practices, in early childhood education, have been laid out in a position paper by NAEYC (2009). These practices are based on the idea that children learn in a progression, both as a group and individually. As an example, children learn to walk by scooting, crawling, pulling themselves up, cruising (walking along the furniture without letting go) and then taking their first steps unassisted. 
Similar progressions can be found in all areas of learning. For each advancement in development, there is a range of ages. However, some children will advance more quickly or slowly. This development cannot occur in a vacuum. Children need challenges, experiences and secure interactions with adults that care for and about them. It is also important for the children to try the challenge for themselves. (NAEYC, 2009) These practices are similar to nature of science and science practices and Mind in the Making life skills.

In an article written for STEM Village in 2016, Walker cited that by 2020 we will have a short fall of 85 million skilled workers for jobs in Science, Technology, Engineering and Mathematics (STEM) fields. Less than half of high school graduates have the STEM instruction required to meet society's needs (Walker, 2017). According to the Programme for International Student Assessment (PISA), the United States of America ranks twenty-fourth out of seventy-one countries in science (Desilver, 2017). As a society our science comprehension is diminishing and our educational system is not up to the task (Desilver, 2017).

There are several explanations for the shortfall in early childhood teachers' preparation to teach science education. Some cite unpleasant past science education experiences. (Conezio and French, 2002) Others list the teachers' beliefs that science is not developmentally appropriate for young children, too messy, and/or there isn't enough time, money, or materials. (Wilson, 2007, Brenneman; Stevenson-Boyd; and Frede, 2009 and Maier; Greenfield; \& Bulotsky-Shearer, 2013)

After having worked in the preschool field for over twenty years, I have found that preschool teachers are generally uncomfortable with science education. We need 
preschool teachers to feel safe not knowing all of the answers, making mistakes and being able to learn about what they do not know with their children. Introducing the early childhood educators to the nature of science and science inquiry may help belay some of those fears and strengthen their understanding of science education in preschool.

The focus of this study is a three-day training on the nature of science and science inquiry for preschool teachers as it relates to Mind in the Making life skills. Most science classes focus on science content, facts, and figures. Science education trainings focus on activities to do with children. This training focuses on how science works, resources that are available in the community for teachers when they are doing a science study, and helping preschool teachers feel comfortable engaging in science in their classroom. What I hope to achieve is a three day training that will improve preschool teachers (1) understanding of Mind in the Making life skills, (2) the nature of science matrix, (3) science practices, and (4) to raise preschool teachers' self-efficacy when engaging in science education in their classrooms.

Mind in the Making life skills focus on developing children's executive functions. The seven life skills addressed in Mind in the Making are focus and self-control, perspective taking, communicating, making connections, critical thinking, taking on challenges, and self-directed, engaged learning (Galinsky, 2010). Each of these life skills are familiar to preschool teachers who already integrate them in their classrooms and will set a solid foundation for science education.

Nature of science and science practices are built on the Mind in the Making foundation. The nature of science is based on eight basic understandings: 1) scientific investigations use a variety of methods, 2) scientific knowledge is based on empirical 
evidence, 3) scientific knowledge is open to revision in light of new evidence, 4) scientific models, laws, mechanisms, and theories explain natural phenomena, 5) science is a way of knowing, 6) scientific knowledge assumes an order and consistency in natural systems, 7) science is a human endeavor, and 8) science addresses questions about the natural and material world (NGSS Lead States, 2013). The science practices that were introduced consist of 1) asking questions and defining problems; 2) planning and carrying out investigations; 3) analyzing and interpreting data; 4) developing and using models; 5) engaging in argument from evidence; 6) obtaining, evaluating and communicating information; and 7) constructing explanations and designing solutions (NRC, 2012). By making connections between Mind in the Making and the nature of science and science practices the teachers can relate the new science based knowledge with life skills they are already familiar with. (Appendix B)

Each day of the training covered a different core idea of science and science education. Each day, also, focused on different community resources that would extend the ability of the teachers to expose their students to science and scientists. Our first day focused on life science and how science was a part of nature and vice versa at Tryon Creek State Natural Area. The second training was at Oregon Museum of Science and Industry where we focused on physical science and how things worked. On the final day we looked at how science can be presented in the classroom at Mt. Hood Community College's Early Childhood Center, both as a study and what a classroom that focuses on science looks like.

After the second training, the teachers were given a homework assignment, in which they introduce and carry out a science investigation with their students, then 
reflect on how the investigation worked. This made up the work sample. At the end of the trainings there was a retrospective pre/post survey. Through the use of surveys and work samples, I saw a change in teachers' perceptions of the nature of science and science education. Student 1a commented "In high school I was never good in math \& science, this training has helped inspire me working in our afterschool and summer program."

By building science understandings onto already familiar theory of mind constructs and giving the teachers multiple opportunities to build on their knowledge and experience, a growth in their self-efficacy in science education would be evident. The teachers' lesson plan worksheets would show that they can set up a science investigation of their own and connect it to Mind in the Making life skills and science practices. The retrospective pre/post survey would, also, indicate the teachers feel more confident teaching science with young children. Analysis of the information from these instruments allowed me to explore my research question: Can a three-day training focusing on the nature of science and science practices as they relate to Mind in the Making make a difference in preschool teachers' self-efficacy engaging in science education? 


\section{Literature Review}

Improving science education in early childhood education has been a point of investigation for many years. Children enjoy exploring the world and asking questions. However, there is a lack of science education in preschool classrooms (Wilson, 2007, Brennaman; Frede; \& Barnett, 2009). This view of science in preschool is amplified by the teachers' limited understanding of the nature of science and science inquiry. Professional development is often the way teachers improve their performance (Duran \& Duran, 2005)

\section{Science Education Gap}

Starting at birth, children experiment on the world around them. In her meta study, Wilson (2007) draws from experts regarding science inquiry in the preschool classroom. Wilson (2007) researched twelve papers regarding the perception that science is generally viewed as abstract, theoretical, formal and just too difficult by early childhood educators. This gives the feeling of science being disconnected from the children's world experience and places the teacher in a role of having to know all the answers. Early childhood educators also have the view point that there can only be one right answer and science should be separated from all the other subjects and areas in the classroom. Based on the findings from these research papers Wilson shows that young children can understand science through hands-on investigation with clear goals in the preschool classroom.

In addition to children's natural interest in science inquiry, the importance of engaging children in science inquiry and the nature of science at a young age comes from research done focusing on the science gap between children from diverse socioeconomic 
backgrounds. Morgan, Farkas, Hillemeir, and Maczuga (2016) did a national longitudinal study following over 7,000 students from kindergarten to the eighth grade. These students represented a cross section of the national demographic make-up. The national testing scores of these students were collected from the fall of 1998 to spring of 2007. The test scores were then divided by demographics and analyzed for differences in science achievement between populations of children. Morgan et al. (2016) started at kindergarten testing the children's science understanding. The differences between populations are evident even at this point. To address this gap, Morgan et al. (2016) recommend the availability of science experiences to children before they start kindergarten.

\section{Preschool Science Education}

Brenneman, Frede and Barnett (2009) reviewed close to ninety papers regarding how science education looks in preschool, how it should look and how to support improving preschool science education. These research papers were reviewed looking for how early childhood educators engage in science. According to this review, science is avoided in the preschool classroom both in the amount of time spent engaging in science learning activities as well as the science area in the classroom. Brenneman et al. found that little time, if any, is set aside in the lesson plan to engage in science education. As for a science area, this is usually relegated to a small out of the way area in the classroom and is one of the classroom centers least likely to be visited by educators to engage with the children. Science is also not integrated into other subjects or education centers. When a spontaneous science experience or interest occurs, little time is spent on exploration or expansion. 
Brennaman et al. (2009) also considered why early childhood educators were not comfortable with science education. Some of the barriers are the beliefs and attitudes of early childhood educators. Some of the beliefs early childhood educators have are based on the idea they need to have all the answers, and that science is not as important as literacy and social skills for kindergarten readiness. Preschool teachers also felt that science is developmentally inappropriate, and too hard, messy, or complicated for early childhood educators and the children. Brenneman et al.'s study also recommended the best way to improve science education in preschool is to improve the understanding preschool teachers have regarding the nature of science and science inquiry. Teachers, whether they are still in school or have been in the field for years, need training and professional development that will help teachers support appropriate science expectations for the preschool classroom (Brenneman et al, 2009).

Both Wilson's (2007) meta study, and Brennaman et al.'s (2009) report found that preschool teachers' past science experiences influence how they view preschool science. A common theme in science education is the memorization of facts, figures, and vocabulary. Science labs have a pass-fail quality, either the student does the experiment right or they failed, with little in the way of discovery as to why the experiment did or didn't work the way it was supposed to. This approach to science education can leave the student frustrated and uncomfortable with science (Brenneman et al, 2009). Are there any other barriers to early childhood educators implementing a science program in preschool classes?

Fantuzzo, Perlman, Sproul, Minney, Perry, and Li (2012) did a survey of 584 teachers from preschool to first grade. Their research focused on understanding 
relationships between teachers' experiences and their classroom experiences. The scale from the survey was used to analyze a correlation between efficacy, job stress and school support. Part of their findings showed that the less overall support teachers felt they had from their supervisors and administrators, the less likely they would engage in science education and other academic subjects. On the other hand, if the teachers felt supported and had higher subject efficacy they would engage more with parents and academic subjects including science.

One of the barriers to bringing science education into the preschool classroom is confidence and comfort. Brenneman et al. (2009) noted discomfort with science in the preschool classroom. The teachers Brenneman et al. surveyed pointed to developmentally inappropriateness of science in the preschool classroom, not knowing all of the answers to children's questions, and the difficulty and messiness of science. Fantuzzo et al. (2012) adds to Brenneman et al.'s findings by adding the element of teacher support. The teachers in Fantuzzo et al.'s 2012 study revealed that the more support from the school the teachers felt they had the greater the chance they would engage in activities outside of their comfort zone, including science. By understanding preschool teachers' beliefs and needs regarding science education, an intervention can be developed.

\section{Preschool Teacher Professional Development}

Understanding the educational backgrounds, beliefs, and concerns of early childhood educators provides trainers with an idea of how to present a program about science inquiry for early childhood educators. In developing this training series, these four themes have been driving forces: 1) how science looks in the preschool classroom, 
2) the view of science by preschool teachers, 3) the importance of science education in the preschool setting, and 4) how to help teachers bring preschool science education into the classroom (Brenneman et al., 2009. NSTA, 2014).

NSTA's (2014) own meta study of nine papers investigated integrating science education into the preschool classroom. NSTA's position paper indicates for a training program to be successful it needs at least five components. These components include: (1) interactive and inquiry based, (2) science specific, (3) ongoing, more than one class, (4) based on the science and engineering practices, and (5) mentoring and opportunities for networking.

This type of training program was presented by Carlton, Fitch and Krockover (2008). They presented a training for thirty fourth to ninth grade teachers that was yearlong. It started in the summer with a two week workshop in which the teachers were asked to solve a "crime" using scientific principles. After the workshop, the teachers were asked to design a lesson plan for their classes that they taught throughout the school year. In October of the next year the teachers presented to their colleagues how their lesson plans worked. Later that day the teachers received a half-day refresher training. The results of this training were measured at four times during the year, prior to the start of the training in the summer to establish a baseline, after the summer training, in the fall, and in the spring using a four point Likert scale. An increase in the teachers' self-efficacy, when teaching science in their classrooms, was demonstrated in the surveys after the summer training and was maintained throughout the rest of the year. Duran and Duran (2005) did a similar study with 55 preschool through third grade teachers from public and private schools. This study used a three phase approach. The 
first phase was fifteen hours of science education trainings focusing on best practices including science inquiry, state and national standards, and teaching practices given after school during the school year. The second phase was a two week hands-on/science inquiry seminar held in the summer focusing on life science, physical science and earth/space science. The teachers in the second phase were introduced to the five E's of science inquiry (engage, explore, explain, elaborate, and evaluate) and community programs and resources to assist them in teaching science (Bybee; Taylor; Gardner; Van Scotter; Powell; Westbrook; \& Landes, 2006). The final phase given during the following summer was five refresher trainings and an opportunity to discuss the successes and failures of the science inquiry lessons they had planned for their students. According to the pre/post survey results the teachers had an increase in confidence and enthusiasm for science education.

NSTA (2014), Carlton, Fitch and Krockover (2008), and Duran and Duran (2005) indicated that developing an effective science education training for preschool teachers has specific components. The training needs to be interactive and hands-on. There needs to be more than one day's worth of class time. The training needs to have a science inquiry basis that focuses on science practices. Opportunities for networking and connecting with community outreach provide part of the lasting components of the training. From this foundation, the Connect with Nature training was developed.

\section{Mind in the Making}

In her book, Mind in the Making, Galinsky (2010) investigated the research of experts in child development. The combined research of these experts shows that there are seven essential life skills that children need to be successful in school and life. The 
life skills are 1) focus and self-control; 2) perspective taking; 3) communication; 4) making connections; 5) critical thinking; 6) taking on challenges; and 7) self-directed, engaged learning. For each life skill Galinsky documents the research that was done to identify the life skill and the importance it plays in the success of children in school and in life. After addressing the research, Galinsky makes suggestions for activities parents and teachers can do with their children in each of the seven life skills.

\section{Nature of Science and Science Practices}

A Framework for K-12 Science Education: Practices, Crosscutting Concepts and Core Ideas (NRC, 2012) were compiled by a group of educators and specialists under direction of the National Research Council. The researchers compiled a framework for science standards developed to progress through each grade from kindergarten through high school. The background of the Framework for K-12 Science Education is to strengthen the American population's understanding of the nature of science and science practices. In our technologically advancing society understanding how science works allows the population to make informed decisions from everything from medical care to political policy to what type of grocery bags to use. Part of their work was to identify the science practices that would set a foundation for developing science standards for the country. To accomplish this task, a committee of researchers, educators and scientists developed the Next Generation Science Standards (NGSS Lead States, 2013) based on the findings from the Framework for K-12 Science Education. Added to the science standards is the Nature of Science Matrix(NGSS, Appendix H), a core understanding of how science works. The Matrix is composed of eight understandings: 1) scientific investigations use a variety of method; 2) scientific knowledge is based on empirical 
evidence; 3) scientific knowledge is open to revision in light of new evidence; 4) scientific models, laws, mechanisms, and theories explain natural phenomena; 5) science is a way of knowing; 6) scientific knowledge assumes an order and consistency in natural systems; 7) science is a human endeavor; and 8) science addresses questions about the natural and material world. Instead of developing curriculum to teach the students this information, the Framework and the NGSS focus on a developmental progression of understandings. Starting with a young child's natural curiosity, the idea behind the Framework is to build on to children's naturally developing executive functions and reasoning to help them better understand science and how it can be used to discover how the world works (NRC, 2012).

The key findings of the researchers, that have been mentioned, indicate that science education in preschool is important and preschool educators need to understand that science is more than memorizing facts and figures (Conezio \& French, 2002, Morgan et al., 2016). Durran \& Durran's (2005) study showed that extended hands-on training improved early childhood educators' self-efficacy and in turn improved their interest in trying hands-on science inquiry with the children in their classrooms. To improve the preschool teachers' self-efficacy and understanding of science education for young children, they need a training program that introduces them to the nature of science and science practices (Brenneman et al., 2009). The training program will need to be more than one day and hands-on with plenty of time for preschool teachers to connect with each other and community resources (NSTA, 2012). This training also needs to integrate science practices with familiar child development practices, in this case Mind in the Making life skills. (Duran \& Duran, 2005, Galinsky, 2010) We will be looking at the 
effect of a three-day training, focusing on the nature of science and science practices as they relate to Mind in the Making, on preschool teachers' self-efficacy engaging in science education. 


\section{Methods}

\section{Overview}

My research aims to find out can a three-day training focusing on the nature of science and science practices as they relate to Mind in the Making make a difference in preschool teachers' self-efficacy engaging in science education. The training program studied was Connect to the Natural World which was held at Tryon Creek State Natural Area, Oregon Museum of Science and Industry (OMSI) and Mt. Hood Community College Early Childhood Center. The participants were early childhood educators from the Portland Metropolitan community who registered for the three day training. The treatment in my research consisted of a three day training that included an assignment to develop a science based lesson plan.

The constructs the training focused on were Mind in the Making life skills, the nature of science and science practices as defined by the NGSS. The Mind in the Making life skills are focus and self-control; perspective taking; communicating; making connections; critical thinking; taking on challenges; and self-directed, engaged learning (Galinsky, 2010). The nature of science constructs are scientific knowledge is based on empirical evidence, scientific knowledge is open to revision in light of new evidence, scientific models, laws, mechanisms, and theories explain natural phenomena, science is a way of knowing, scientific knowledge assumes an order and consistency in natural systems, science is a human endeavor, science addresses questions about the natural and material world (NGSS Lead States, 2013, Appendix H). The scientific practices that were covered in this training are asking questions, developing and using models, planning and carrying out investigations, analyzing and interpreting data, and constructing 
explanations (NRC, 2012). The effects of the training were measured with a lesson plan work sample and a pre/post retrospective survey.

\section{Program and Locations}

Connect to the Natural World was a science based training for early childhood educators. Due to an overwhelming response to the offering there were two trainings. One was presented in three monthly, five-hour sessions in the fall from October to January with a break in December. The second training was three monthly, five hour sessions from March to May.

These trainings were designed by Stephanie Wagner and Colleen Meacham based on research done by Carlton, Fitch, \& Krockover (2007), Duran \& Duran (2002), and the position paper of the NSTA (2014) to introduce science concepts to early childhood educators in a manner similar to the way they would interact with their students. The goal was to improve the early childhood educators' comfort with science education. Three sites, with different science orientations, were used to allow the teachers exposure to a variety of community resouurces. Tryon Creek State Natural Area, an urban forest in Portland, Oregon, was used for the life science portion of the training. Oregon Museum of Science and Industry (OMSI), in Portland, Oregon, was used for the physical science portion of the training. Finally, Mt. Hood Community College in Gresham, Oregon was used for the teaching/education portion of the training. All sections of this training focused on introducing science inquiry and the nature of science in an appropriate format for preschool children.

\section{Participants}

The participants were recruited from a flier that was circulated through Child Care 
Resource and Referral of Multnomah and Child Care Resource and Referral of Clackamas County. The venues that hosted our trainings also put an announcement in their newsletters to educators. I also conducted word of mouth advertising for the trainings with teachers I knew needed professional development hours.

All participants that registered for the Connect to Nature Training from October 2016 to January 2017 and March 2017 to May 2017 were invited to participate in my research. The participant population consisted of 75\% English speaking students and 25 $\%$ identified as Spanish speaking. We had two students that were African- American and one Arabic student. Half of the students identified as college graduates, from an associate's degree to a master's degree. Ninety percent of the participants were women.

\begin{tabular}{|l|l|}
\hline Teacher Education & \# teachers \\
\hline High School & $\mathbf{3}$ \\
\hline Some College & $\mathbf{9}$ \\
\hline Associate Degree & $\mathbf{1}$ \\
\hline Bachelor's Degree & $\mathbf{9}$ \\
\hline Master's Degree & $\mathbf{3}$ \\
\hline Other & $\mathbf{1}$ \\
\hline No Answer & $\mathbf{5}$ \\
\hline
\end{tabular}

Table 1: Teacher Education Level

\begin{tabular}{|l|l|}
\hline Teacher Gender & \# teachers \\
\hline Male & $\mathbf{3}$ \\
\hline Female & $\mathbf{2 5}$ \\
\hline No Answer & $\mathbf{3}$ \\
\hline
\end{tabular}

Table 3: Teacher Gender

\begin{tabular}{|l|l|}
\hline $\begin{array}{l}\text { Teacher Experience } \\
\text { (in years) }\end{array}$ & \# teachers \\
\hline $1-5$ years & $\mathbf{5}$ \\
\hline $6-10$ years & $\mathbf{9}$ \\
\hline $11-15$ years & $\mathbf{2}$ \\
\hline $16-20$ years & $\mathbf{5}$ \\
\hline $21+$ years & $\mathbf{6}$ \\
\hline No Answer & $\mathbf{2}$ \\
\hline
\end{tabular}

Table 2: Teacher Experience in years

\begin{tabular}{|l|l|}
\hline Teacher Age Group & \# teachers \\
\hline Under 21 & $\mathbf{0}$ \\
\hline $21-30$ & $\mathbf{3}$ \\
\hline $31-40$ & $\mathbf{5}$ \\
\hline $41-50$ & $\mathbf{9}$ \\
\hline $51-60$ & $\mathbf{7}$ \\
\hline $61+$ & $\mathbf{3}$ \\
\hline No Answer & $\mathbf{4}$ \\
\hline
\end{tabular}

Table 4: Teacher Age Group 
There were a total of twenty early childhood educators in training one and twentyone early childhood educators in training two who registered for the Connect to Nature training for a total of forty-two participants. A total of fourteen early childhood educators selected to participate in the study after the first training and seventeen selected to participate after the second training for a total of thirty-one research participants.

\section{Treatment: The Three Day Training}

There were three days of trainings that were held once per month. The dates of the first training were October $15^{\text {th }}, 2016$; November $19^{\text {th }}, 2016$; and January $21^{\text {st }}, 2017$. The second training was on March4 $4^{\text {th }}, 2017$; April15 $5^{\text {th }}, 2017$ and May20 ${ }^{\text {th }}, 2017$.

The first day of training we met at Tryon Creek State Natural Area and explored life science. The participants were given an opportunity to go for a nature walk and observe worms. Using an Observe, Wonder, and Learn about chart (O.W.L. chart), the participants were asked to drill down from just observing to coming up with questions and ways of answering those questions. These activities gave the participants a chance to experience science inquiry without feeling graded and increase their self-efficacy in science education. Table 5 outlines the day's activities and supported research construct. 


\begin{tabular}{|c|c|}
\hline Day 1 Activities & $\begin{array}{l}\text { Construct Supported: } \\
\text { SEP - Science and Engineering Practice } \\
\text { MIM - Mind in the Making } \\
\text { NOS - Nature of Science }\end{array}$ \\
\hline $\begin{array}{ll}\text { Senses } & \text { Walk } \\
\text { 1. } & \text { Walk with senses observation prompt } \\
\text { 2. } & \text { Organize observations into OWL Chart } \\
\text { 3. } & \text { Discussion of how teachers can answer } \\
\text { the questions generated with preschoolers }\end{array}$ & $\begin{array}{l}\text { 1. NOS - Science assumes an order and } \\
\text { consistency (patterns) in natural } \\
\text { systems }\end{array}$ \\
\hline $\begin{array}{l}\text { What is Science? Exploration } \\
\text { 1. Make of list of how science affects your } \\
\text { life. } \\
\text { 2. Organize the list into categories. } \\
\text { 3. Discussion of how science is a part of our } \\
\text { lives - not something done apart from } \\
\text { society }\end{array}$ & $\begin{array}{l}\text { 1. SEP 4 - Gathering data } \\
\text { 2. SEP 4 - Analyzing data } \\
\text { 3. NOS - Science uses a variety of methods } \\
\text { is based on empirical } \\
\text { evidence } \\
\text { is open to revisions } \\
\text { explains natural phenomena }\end{array}$ \\
\hline $\begin{array}{l}\text { Worm Walk and Investigation } \\
\text { 1. Exploration walk looking for worm } \\
\text { mounds } \\
\text { 2. Observe worm structures and behaviors } \\
\text { 3. Investigation of a worm observation }\end{array}$ & $\begin{array}{l}\text { 1. SEP } 1 \text { - Making observations } \\
\text { MIM } 1 \text { - Focus and self-control } \\
\text { MIM } 2 \text { - Self-directed engaged learning } \\
\text { 2. SEP 1 - Making observations } \\
\text { MIM } 1 \text { - Focus and self-control } \\
\text { MIM } 4 \text { - Making connections } \\
\text { SEP 1 - Asking questions } \\
\text { 3. SEP } 3 \text { - Planning and carrying out } \\
\text { investigations } \\
\text { SEP } 4 \text { - analyzing and interpreting data } \\
\text { SEP } 5 \text { - construction explanations } \\
\text { MIM } 3 \text { - communicating } \\
\text { MIM } 4 \text { - making connections } \\
\text { MIM } 5 \text { - critical thinking } \\
\text { MIM } 7 \text { - self-directed engaged learning } \\
\text { NOS - Science uses a variety of methods } \\
\text { is based on empirical } \\
\text { evidence } \\
\text { explains natural phenomena }\end{array}$ \\
\hline
\end{tabular}

Table 5: First Day of Training

Oregon Museum of Science and Industry (OMSI) hosted our second day of

training. This training focused on physical science; properties of matter and force and

motion. Again, we used an O.W.L. chart to help the participants focus on what they were observing, wondering and wanted to learn. We focused more on the nature of science and that answers that are not what is expected are not necessarily wrong, just different. 
Table 6 outlines the second day's activities and associated research construct.

\begin{tabular}{|c|c|}
\hline Day 2 Activities & $\begin{array}{l}\text { Construct Supported } \\
\text { SEP - Science and Engineering Practice } \\
\text { MIM - Mind in the Making } \\
\text { NOS - Nature of Science }\end{array}$ \\
\hline $\begin{array}{l}\text { Mind in the Making - Skits } \\
\text { 1. Review Mind in the Making life skills and } \\
\text { connect them to science practices and the } \\
\text { nature of science constructs } \\
\text { 2. Develop a skit demonstrating how the } \\
\text { assigned Mind in the Making life skill can be } \\
\text { used in science education } \\
\text { 3. Presentation of skits and discussion of the } \\
\text { life skill presented. }\end{array}$ & $\begin{array}{l}\text { 1. SEP } 4 \text { - Gathering data } \\
\text { 2. SEP } 4 \text { - Analyzing data } \\
\text { MIM } 6 \text { - Taking on challenges } \\
\text { MIM } 7 \text { - Self-directed, engaged learning } \\
\text { 3. SEP } 5 \text { - Constructing Explanations } \\
\text { MIM } 3 \text { - Communicating } \\
\text { MIM 4- Making connections } \\
\text { MIM } 5 \text { - Critical thinking } \\
\text { NOS - Science uses a variety of methods }\end{array}$ \\
\hline $\begin{array}{l}\text { What is Matter? Probe and Exploration (Kelley 2010) } \\
\text { 1. Using a worksheet choose which of the } \\
\text { objects are matter. } \\
\text { 2. Investigation of air as matter. }\end{array}$ & $\begin{array}{l}\text { 1. MIM } 4 \text { - Making connections } \\
\text { MIM } 5 \text { - Critical thinking } \\
\text { 2. SEP } 1 \text { - Asking questions and making } \\
\text { observations } \\
\text { SEP 2 - Developing and using models } \\
\text { SEP } 3 \text { - Planning and carrying out } \\
\text { investigations } \\
\text { SEP } 4 \text { - Gathering and analyzing data } \\
\text { MIM 1 - Focus and self-control } \\
\text { MIM } 2 \text { - Self-directed engaged learning } \\
\text { 3. SEP 5 - Constructing explanations } \\
\text { MIM } 3 \text { - Communicating } \\
\text { NOS - Science uses a variety of methods } \\
\text { is based on empirical } \\
\text { evidence } \\
\text { explains natural phenomena }\end{array}$ \\
\hline $\begin{array}{l}\text { Marble Roll Probe and Exploration (Kelley, 2010) } \\
\text { 1. Using a worksheet choose how the marble will } \\
\text { roll once it leaves the spiral ramp. } \\
\text { 2. Investigate the marbles' behavior after it leaves a } \\
\text { spiral ramp }\end{array}$ & $\begin{array}{l}\text { 1. MIM } 4 \text { - Making connections } \\
\text { MIM 5 - Critical thinking } \\
\text { 2. SEP1 - Asking questions and making } \\
\text { observations } \\
\text { SEP 2 - Developing and using models } \\
\text { SEP 3 - Planning and carrying out } \\
\text { investigations } \\
\text { SEP } 4 \text { - Gathering and analyzing data } \\
\text { MIM 1 - Focus and self-control } \\
\text { MIM 2 - Self-directed engaged learning } \\
\text { MIM 4 - Making connections } \\
\text { SEP 5 - Constructing explanations } \\
\text { MIM 3 - Communicating } \\
\text { NOS - Science is based on empirical } \\
\text { evidence } \\
\text { explains natural } \\
\text { phenomena }\end{array}$ \\
\hline
\end{tabular}

Table 6: Second Day of Training 
Our last training was held at Mt. Hood Community College Early Childhood Center. In this training, we reviewed science lessons the participants did with their classes. Participants gave each other suggestions for extensions and resources. We also focused on how to engage students in asking questions during a science investigation. The end of the training we toured the school to look at how different teachers integrate science into their classrooms. Table 7 outlines the third day activities and associated research constructs.

\begin{tabular}{|c|c|}
\hline Day 3 Activities & $\begin{array}{l}\text { Construct Supported } \\
\text { NOS - Nature of Science } \\
\text { SEP - Science and Engineering Practice } \\
\text { MIM - Mind in the Making }\end{array}$ \\
\hline $\begin{array}{l}\text { Review teachers' investigations } \\
\text { 1. Discuss the investigations each teacher did } \\
\text { with the children in their classes, including } \\
\text { suggestions for extensions, in small and large } \\
\text { groups. }\end{array}$ & $\begin{array}{l}\text { 1. SEP 3 - Planning and carrying out } \\
\text { investigations } \\
\text { SEP 5 - Constructing explanations } \\
\text { MIM 1 - Focus and self-control } \\
\text { MIM 3 - Communicating } \\
\text { MIM 4 - Making connections } \\
\text { MIM 5 - Critical Thinking } \\
\text { MIM 6 - Taking on challenges } \\
\text { MIM } 7 \text { - Self-directed engaged learning } \\
\text { NOS - Science investigations use a variety } \\
\text { of methods } \\
\text { addresses questions about the } \\
\text { natural and material world }\end{array}$ \\
\hline $\begin{array}{l}\text { Science demonstration } \\
\text { 1. Engage the teachers in answering children's } \\
\text { questions while they try to explain what they } \\
\text { are observing }\end{array}$ & $\begin{array}{l}\text { 1. SEP 1 - Asking questions and making } \\
\text { observations } \\
\text { SEP } 4 \text { - Gathering and analyzing data } \\
\text { SEP } 5 \text { - Constructing explanation } \\
\text { MIM } 1 \text { - Focus and self-control } \\
\text { MIM } 3 \text { - Communicating } \\
\text { MIM5 - Critical thinking } \\
\text { NOS - Science is a way of knowing } \\
\text { addresses questions about the } \\
\text { natural and material world }\end{array}$ \\
\hline $\begin{array}{l}\text { School Tour } \\
\text { 1. The teachers toured the Early Childhood } \\
\text { Center at Mt. Hood Community College } \\
\text { to view science education in a preschool } \\
\text { classroom. }\end{array}$ & $\begin{array}{l}\text { 1. SEP } 1 \text { - Asking questions and making } \\
\text { observations } \\
\text { SEP } 4 \text { - Gathering and analyzing data } \\
\text { MIM } 1 \text { - Focus and self-control } \\
\text { MIM } 2 \text { - Perspective taking } \\
\text { MIM } 4 \text { - Making connections } \\
\text { MIM } 7 \text { - Self-directed, engaged learning } \\
\text { NOS - Science is a way of knowing }\end{array}$ \\
\hline
\end{tabular}

Table 7: Third day of training 


\section{Measurement Instruments}

The measurement instruments utilized were 1) the lesson plan work sample to be completed between the second and third trainings, 2) a pre/post retrospective survey with a Likert scale and, 3) an open ended question section of the survey. This survey was given at the end of the three training days.

\section{Work Sample - Lesson Plan}

The take home lesson plan template was designed to give a practical view of how the participants utilized the training in their classrooms. The participants were asked to choose a topic and come up with a question to investigate based on the interests and questions of the children in their classrooms. The template starts by having the participants describe the study they were doing, the big idea behind it, and the goal of the lesson. The next section used the Biological Sciences Curriculum Study (BSCS) 5E Instructional Model to guide the science inquiry lesson. The 5E's are: engage, explore, explain, elaborate and evaluate (Bybee et al, 2006). Each section was accompanied by two boxes where the participants were to connect the five areas to both science practices and Mind in the Making life skills. The last section was for the participants to reflect on how the study went and what they might change or add. A copy of the lesson plan template can be found in Appendix E.

By looking at the way the educators implemented science in their classrooms, an observation of how well they understood the concepts presented in the training was analyzed. The reflections of the studies also provided insight into how comfortable the participants were with implementing science inquiry, the science practices and the nature of science. 


\section{Pre/Post Retrospective Survey and Analysis}

According to Brennneman (2011) and Funtuzzo et al (2012), a Likert scale survey provides a snap shot into participants' attitudes regarding science education. There are two ways to present the survey: 1) give the participants a survey before the intervention begins and then again after the intervention is over or 2) give the participants a pre/post retrospective survey at the end of the intervention. The pre/post retrospective survey was chosen to eliminate the possibility that the participants might have a higher estimate of their abilities at the beginning of the intervention and a lower estimation at the end. Using the pre/post retrospective survey demonstrates the participants' estimation of their change in attitudes.

The questions on the pre/post retrospective survey used in this research were taken from the research done by Riggs \& Knochs (2011). These questions were then reviewed by my classmates and professors. Revisions were made to the survey questions to help the questions match the current research, producing a modified survey. One of the revisions suggested was to add an area for the participants to explain their responses on the Likert scale providing deeper insight into any changes in attitudes.

The pre/post retrospective survey was analyzed to see how much the participants perceived their understanding of the nature of science, science practices, Mind in the Making and their self-efficacy regarding science education had changed. The pre-post retrospective survey consisted of fifteen questions each with both a four point Likert scale and a comments section. (See Appendix G) There were three questions focusing on science practices, four questions focused on the nature of science, and eight questions asked about the educators' self-efficacy regarding science education. For each question 
participants were asked how they felt before and after the training with a comment section asking them to explain why they answered the way they did.

\section{Data Analysis}

A table was made of the participants' pre-training beliefs in one column, a column for their post-training beliefs, and the last column calculated the change between the two other columns. The results of the survey were analyzed using the Wilcoxon-Signed Ranked Test, because of the small sample size (Stagroom, 2017). For each of the questions, the teachers' pre- and post- scores were compared. The pre- and post- scores were tested to analyze the null hypothesis against an alternative hypothesis, to determine whether significant differences exist between two sample groups.

The statements were analyzed for comments about changes in the participants' perceptions. Using a rubric (Appendix $\mathrm{H}$ ) the comments were assessed for depth of understanding: $0=$ no comment, $1=$ limited comment, $2=$ a comment that directly addresses the question, but superficially, and $3=$ a comment that describes how the participant grew during the training and how they will continue to utilize what they learned. Next the comments were divided into three categories 1) neutral, a comment that does not indicate a change took place; 2) positive, a comment that indicates a change in the direction the training was focusing on; and 3) negative, a comment that indicates a change in the opposite direction of the training.

There were four points that the work samples were assessed for: 1) connection of the lesson plan to a core science idea (structure and function, force and motion, properties of matter, and patterns), 2) connection of the five "E's" of science inquiry (engage, explore, explain, elaborate, and evaluate) to science practices, 3) connection of the five 
"E's" of science inquiry to Mind in the Making life skills and 4) how the activity supports understanding the nature of science. The connection of the lesson plan to a core science idea was analyzed using a three point scale $1=$ an answer, $2=$ the topic is well explained and connected to a big idea, $3=$ the topic is well explained, connected to a big idea and the connection is demonstrated in the lesson plan. The connection of the five "E's" to both the science practices and Mind in the Making life skills were analyzed using a two point scale: $1=$ no answer or an unrelated answer, $2=$ an answer that matches the aspect of the lesson plan that was being addressed. How the activity supports understanding the nature of science was analyzed using a three point scale: $1=$ an answer, $2=$ an answer about the conclusions the experiment made, ie. metal attracts magnets, and $3=$ the activity is connect to the nature of science and science practices that were used in the activity). The rubric is in Appendix F.

\section{Summary}

A three-day training focusing on the nature of science and science practices as they relate to Mind in the Making was developed. Thirty-one early childhood educators completed the training and gave consent/assent to participate in the research study. The early childhood educators were asked to complete a lesson plan worksheet and a pre/post retrospective survey with a short answer section. The lesson plans and survey were analyzed to answer the research question: Can a three-day training focusing on the nature of science and science practices as they relate to Mind in the Making make a difference in preschool teachers' self-efficacy engaging in science education? 


\section{Results}

The data collected show the effect of a three-day training toward improving preschool teachers' understanding of Mind in the Making, the nature of science and science inquiry, and the teachers' self-efficacy when engaging in science inquiry with their students.

The information compiled from the pre-/post- retrospective survey and the lesson plans was translated into the figures presented here. Some of the teachers exhibited a ceiling effect, where they answered at the highest level on both pre and post survey. These answers were eliminated from the pool. The resulting number of answers, after the ceiling effect was removed, were calculated for change. For the comments, if a teacher did not answer, that response was eliminated. The following figures show the number of teachers that answered with a specific Likert scale number and the number of teachers that had a certain level of change after removing the ceiling effect. Below those figures are the figures for the short answer responses.

\section{Mind in the Making}

The concept behind Mind in the Making (Galinsky, 2010) is there are certain skill sets that help children succeed in school and life. Most of these concepts are reinforced by understanding the nature of science and science inquiry and one of the goals of the trainings was to develop the teacher's understanding of Mind in the Making as it pertains to science education (See Appendix B).

Figures $1 \mathrm{a}-3 \mathrm{~b}$ show how the teachers gained a better understanding of how science can help their students become more successful by connecting science practices and language to Mind in the Making life skills and language. Figures 1a \& b look at an 
understanding of the Mind in the Making life skill critical thinking and the science practice of constructing explanations. Specifically, can the teachers help their students encounter something new and ask questions, and construct explanations for better understanding? Figures 2a \& b look at the Mind in the Making life skill of problem solving, which includes making connections and taking on challenges. Figures $3 \mathrm{a} \& \mathrm{~b}$ show development in being able to adapt science lessons to increase the children's Mind in the Making life skill of self-directed and engaged in their learning, including improving the children's focus, self-control and perspective taking, similar to the science practice of planning and carrying out investigations and the nature of science practice of scientific investigations use a variety of methods and science is a way of knowing (Galinsky, 2010; National Research Council, 2012; NGSS Lead States, 2013).

As Figure 1a shows, even with a ceiling effect of fifteen teachers, there was a definite shift in the remaining sixteen teachers' thinking about science education as a way to help children become critical thinkers.

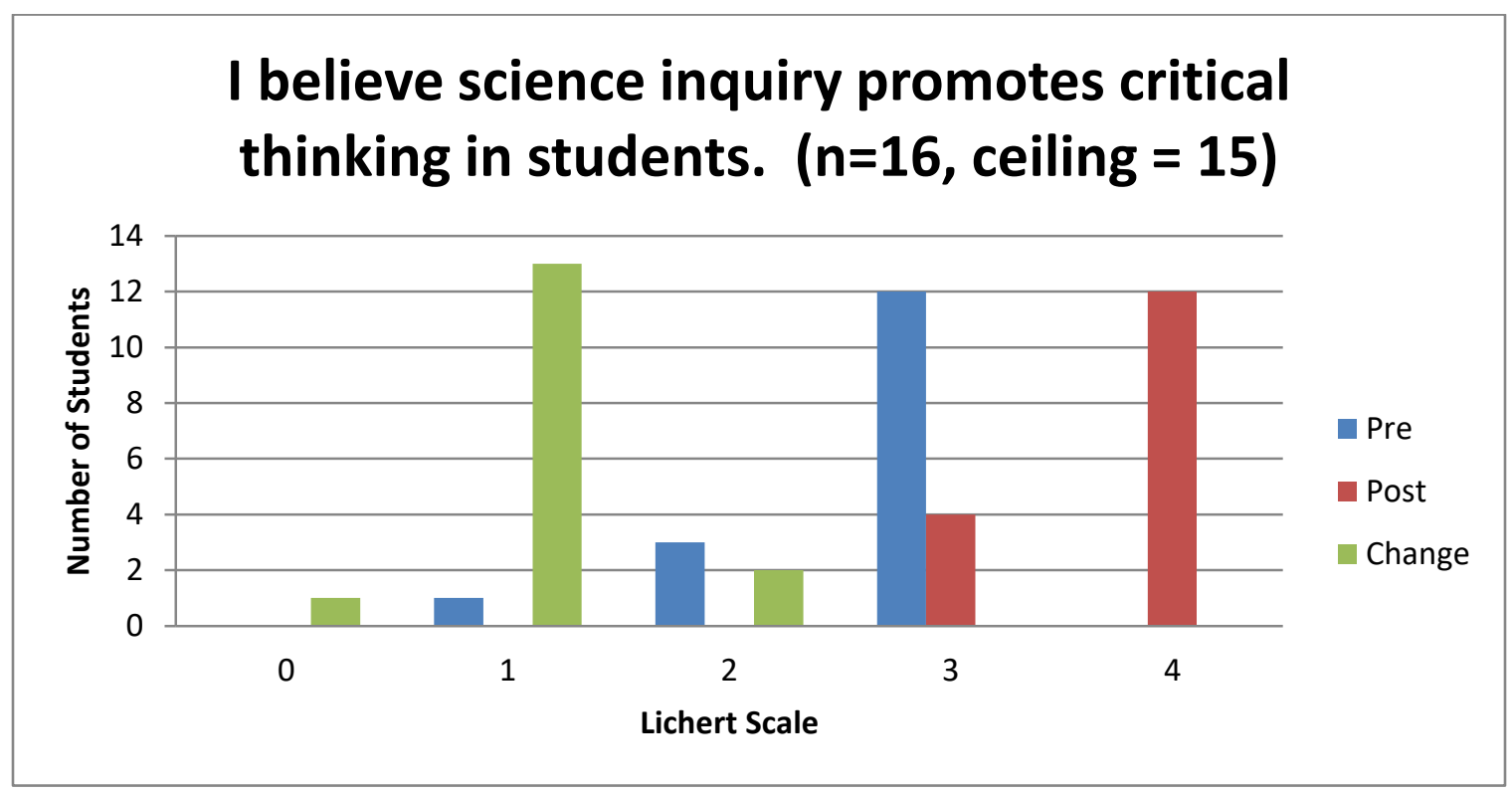

Figure 1a: I believe science inquiry promotes critical thinking in students. - Likert Scale 


\begin{tabular}{|l|l|}
\hline \multicolumn{2}{|l|}{ Result Details: I believe science inquiry promotes critical thinking in students. } \\
\hline W-value & 0 \\
\hline Mean Difference & -1.4 \\
\hline Sum of Pos. Ranks & 0 \\
\hline Sum of Neg. Ranks & 120 \\
\hline Z-value & -3.4078 \\
\hline Mean (W) & 60 \\
\hline Standard Deviation (W) & 17.61 \\
\hline p-value at p $\leq 0.05$ & 0.00064 \\
\hline Sample Size $(\mathrm{N})$ & 16 \\
\hline
\end{tabular}

Table 8: I believe science inquiry promotes critical thinking in students statistical analysis

The comments in Figure 1b show that almost half of the students perceived growth in how they connected science education to developing critical thinking in preschool students.



Figure 1b: I believe science inquiry promotes critical thinking in students. - Comments

The teachers also increased their perceived understanding that science education increased the children's ability to problem solve based on the results shown in Figure 2a. Of the 18 teachers that were not part of the ceiling effect, 16 of them increased their understanding. 


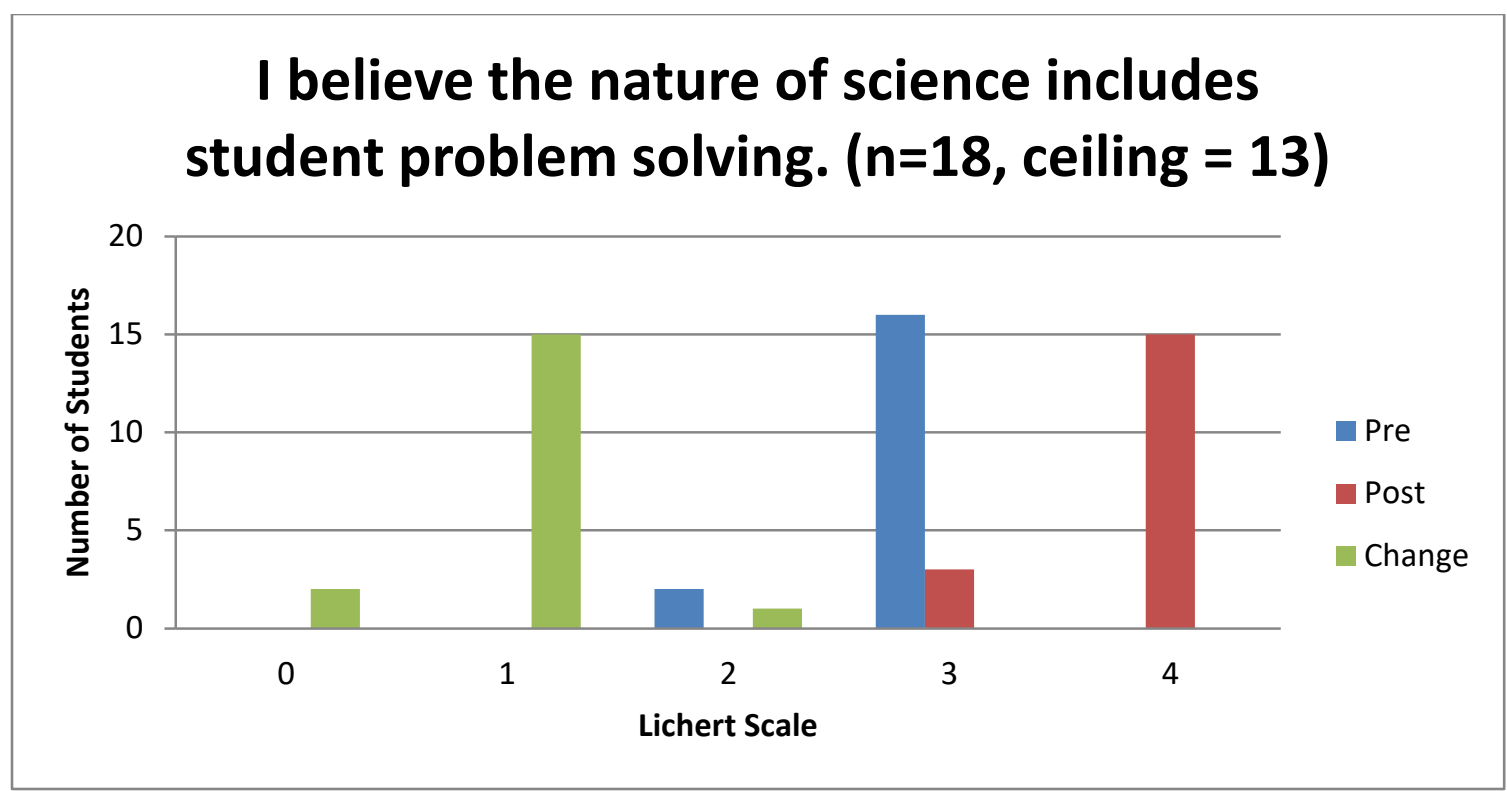

Figure 2a: I believe the nature of science includes student problem solving. - Likert Scale

\begin{tabular}{|l|l|}
\hline \multicolumn{2}{|l|}{ Result Details: I believe the nature of science includes student problem solving. } \\
\hline W-value & 0 \\
\hline Mean Difference & 0.69 \\
\hline Sum of Pos. Ranks & 0 \\
\hline Sum of Neg. Ranks & 136 \\
\hline Z-value & -3.5162 \\
\hline Mean (W) & 68 \\
\hline Standard Deviation $(\mathrm{W})$ & 19.34 \\
\hline p-value at p $\leq 0.05$ & 0.00044 \\
\hline Sample Size $(\mathrm{N})$ & 18 \\
\hline
\end{tabular}

Table 9: I believe the nature of science includes student problem solving statistical analysis.

The comments presented in Figure $2 \mathrm{~b}$ indicate that approximately two-thirds of the participants perceived a growth in how science promotes problem solving in preschool students. The one teacher that indicated a negative growth commented, "When the child sees a result enough times they will come to their own decision." 


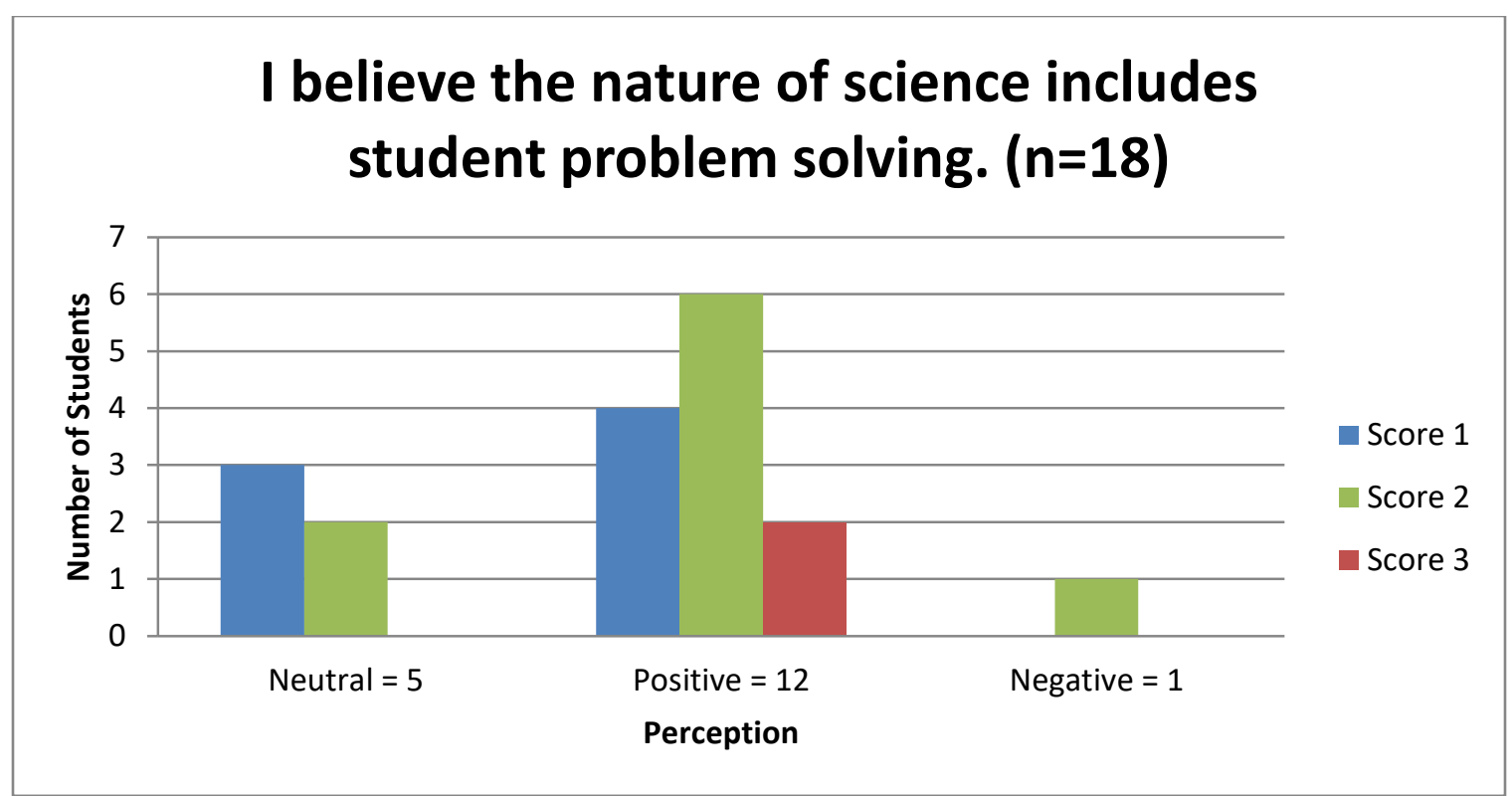

Figure 2b: I believe the nature of science includes student problem solving. - Comments

The question below addresses the concept that children will develop at their own pace and explore ideas that are not outlined in the planned curriculum and teachers need to have the expertise to be able to adapt to meet the needs of their students (Head Start, 2015). Being able to adapt the lesson to meet the children's needs shows that the teacher understands that focus, self-control, and self-directed, engaged learning are important and the teacher can demonstrate and model perspective taking (Galinsky, 2010). Twenty- two of the teachers indicated an increase in their comfort level with this concept as shown in Figure 3a. The one teacher that demonstrated a negative response was one of the ELL teachers. She did comment "and making moor connection". 


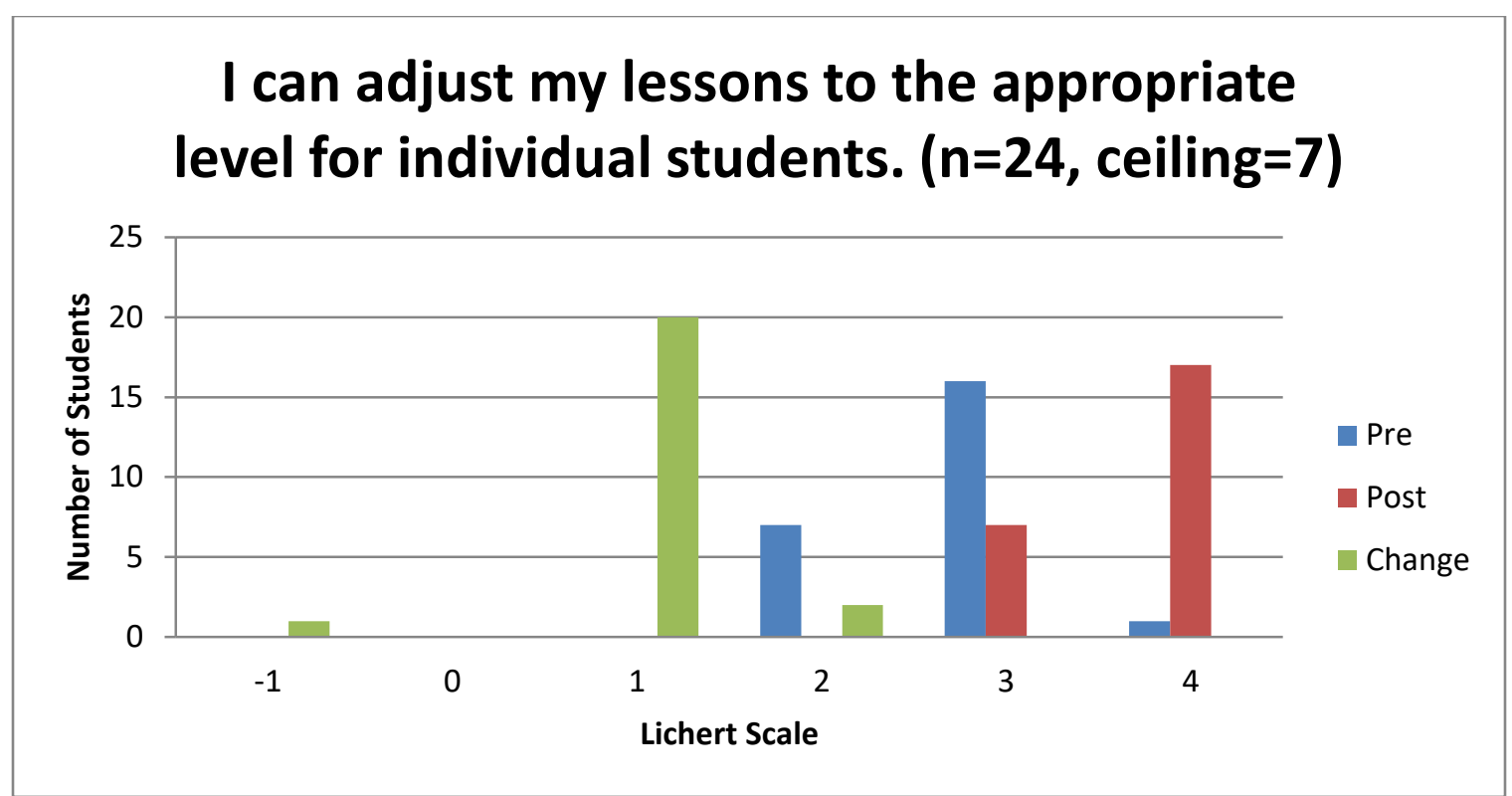

Figure 3a: I can adjust my lessons to the appropriate level for individual students. - Likert Scale

\begin{tabular}{|l|l|}
\hline \multicolumn{2}{|l|}{ Result Details: I can adjust my lessons to the appropriate level for individual students. } \\
\hline W-value & 11 \\
\hline Mean Difference & 0.04 \\
\hline Sum of Pos. Ranks & 11 \\
\hline Sum of Neg. Ranks & 265 \\
\hline Z-value & -3.8627 \\
\hline Mean (W) & 138 \\
\hline Standard Deviation $(\mathrm{W})$ & 32.88 \\
\hline p-value at p $\leq 0.05$ & 0.00012 \\
\hline Sample Size $(\mathrm{N})$ & 24 \\
\hline
\end{tabular}

Table 10: I can adjust my lessons to the appropriate level for individual students statistical analysis.

Figure $3 \mathrm{~b}$ again indicates a greater percentage of the participants perceived a positive growth in their ability to develop lessons that allowed their students to be engaged in their learning but still take on challenges. 


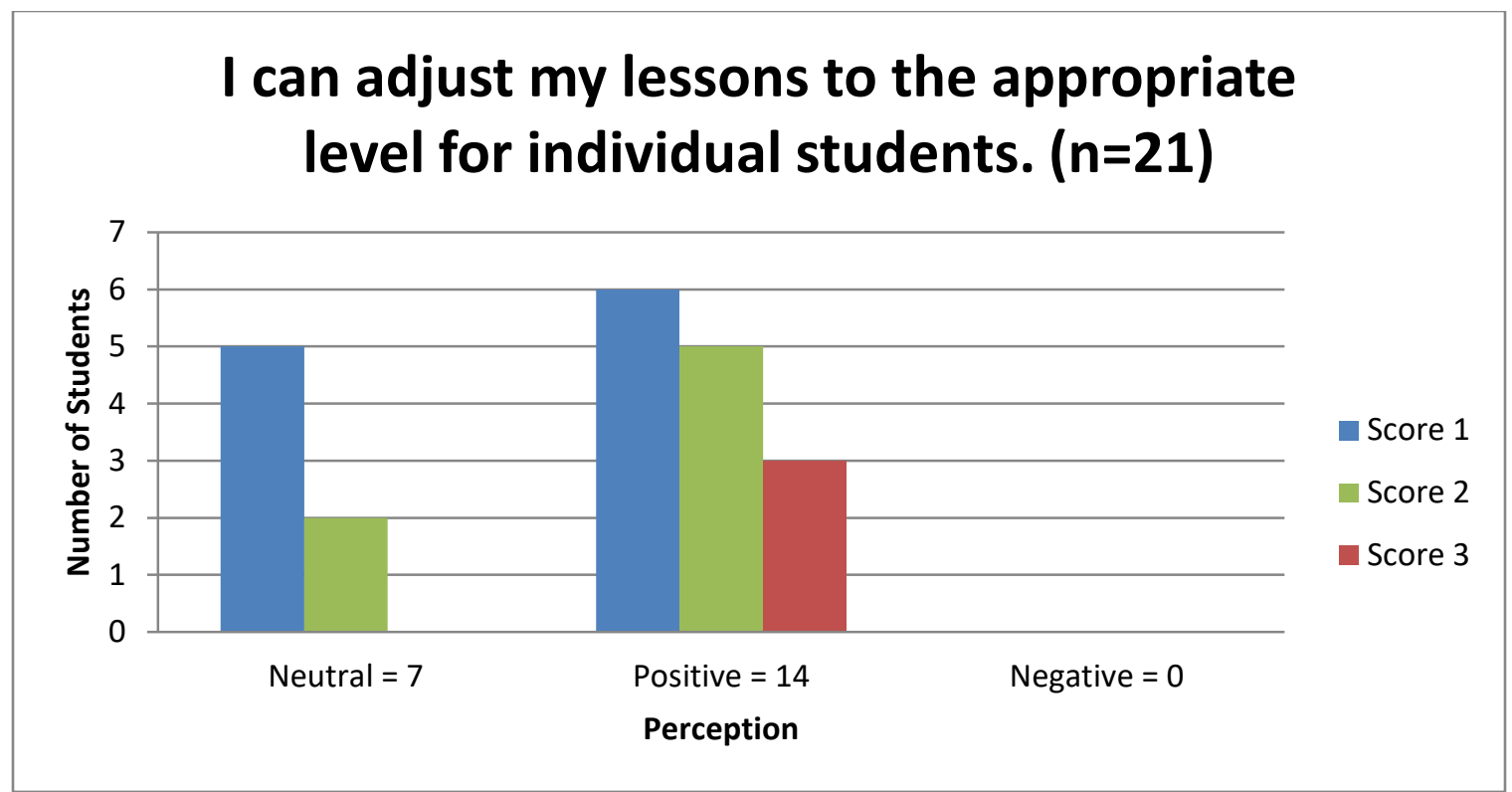

Figure 3b: I can adjust my lessons to the appropriate level for individual students. - Comments

All three of the above questions showed statistically significant changes for the

Likert scale with p-values for each question less than 0.05, as shown in Tables 8-10. This allows for a rejection of the null hypothesis: teachers, who participated in the training, will not show a gain in the perception of the nature of science and science inquiry as it relates to Mind in the Making skills sets. This allows us to accept the alternative hypothesis: teachers, who participated in the training, will show a gain in the perception of the nature of science and science inquiry as it relates to Mind in the Making skills sets.

\section{Self-Efficacy}

As has been mentioned by several studies (Brenneman; Stevenson-Boyd; and Frede, 2009 Maier; Greenfield; \& Bulotsky-Shearer, 2013), science is considered too hard, too time consuming, and teachers do not have the resources necessary to do science in the classroom.

Below are Figures 4a through 9b that demonstrate how the teachers' views of their ability to teach science changed. Figures $4 \mathrm{a}$ through $5 \mathrm{~b}$ are from questions that 
show how the teachers changed their perceptions in their ability to lead a science investigation with their students. The two questions from these figures were also presented in the negative to limit the teachers' urge to just answer in the positive. Figures $6 \mathrm{a} \& \mathrm{~b}$ show how the teachers changed their views on their ability to understand science concepts. Figures $7 \mathrm{a}$ through $8 \mathrm{~b}$ show how the teachers improved how they feel about children asking questions. Finally, Figures $9 \mathrm{a} \& \mathrm{~b}$ focus on the skills the teachers believe they have in order to teach science inquiry and the nature of science.

Figure 4a below shows the first of the questions that was presented in a negative statement. Of the thirteen teachers that scored themselves as agreeing more with the statement, the ones that commented stated that they feel more confident teaching science. For example Student 4 commented, "After the first class I felt a little bit more confident about the subject. I can teach science with out being fear to teach wrong”. Student 4a commented, "I enjoy science more than any other subject." Student 13a's comment was "Since taking this class I have done more science activities." There were five more comments regarding an enjoyment of science education in the preschool classroom. Two of the teachers that scored themselves lower did not leave a comment, and two of the comments did not relate to the question. 


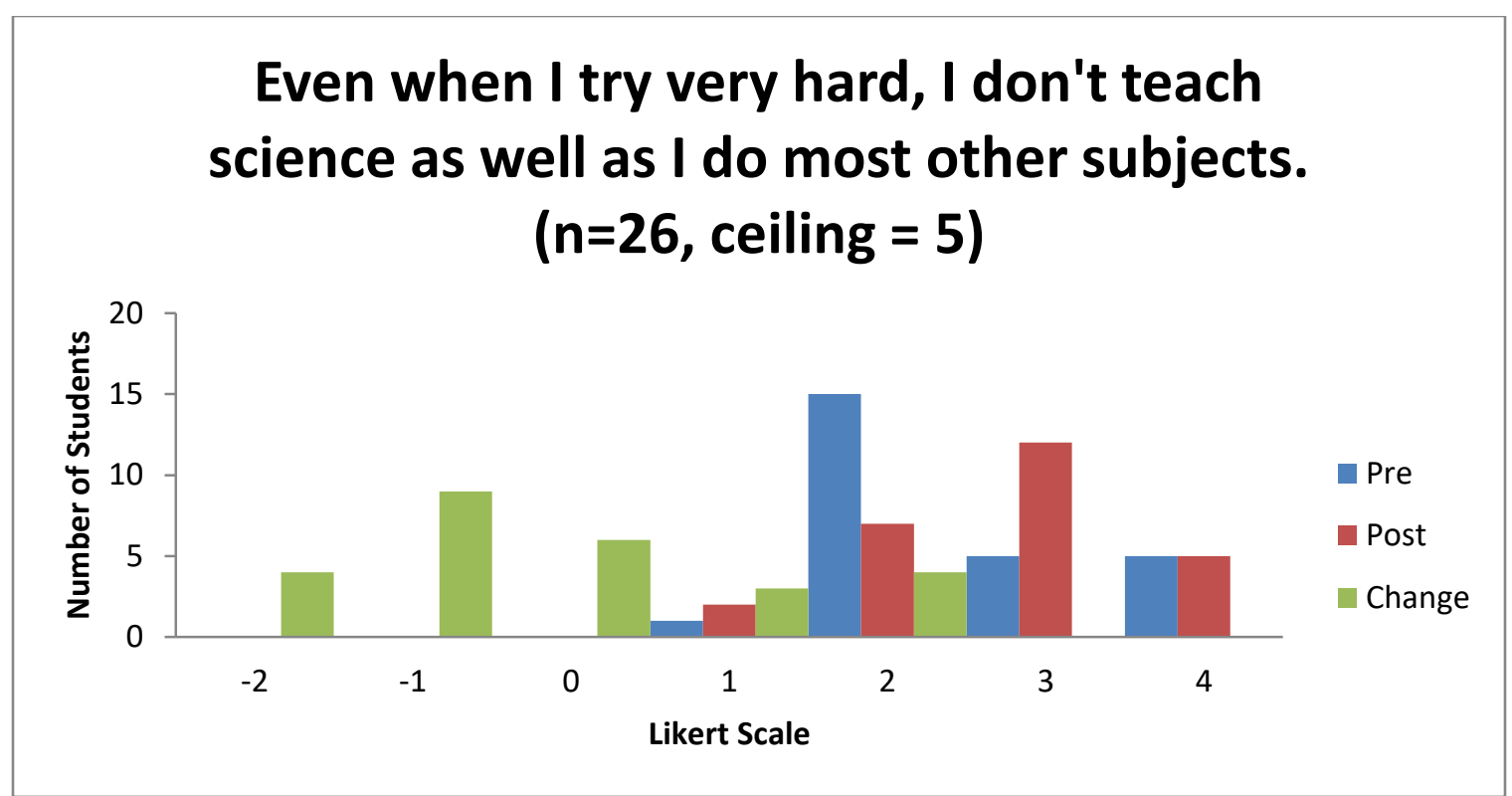

Figure 4a: Even when I try very hard, I don't teach science as well as I do most other subjects.-Likert scale

\begin{tabular}{|l|l|}
\hline \multicolumn{2}{|l|}{ Result Details: Even when I try very hard, I don't teach science as well as I do most other subjects. } \\
\hline W-value & 85.5 \\
\hline Mean Difference & -2.65 \\
\hline Sum of Pos. Ranks & 85.5 \\
\hline Sum of Neg. Ranks & 124.5 \\
\hline Z-value & -0.728 \\
\hline Mean (W) & 105 \\
\hline Standard Deviation (W) & 26.79 \\
\hline p-value at p $\leq 0.05$ & 0.4654 \\
\hline \hline Sample Size $(\mathrm{N})$ & 26 \\
\hline
\end{tabular}

Table 11: ... I don't teach science as well as I do most other subjects statistical analysis

Figure $4 \mathrm{~b}$ shows how the teachers comments regarding their ability to teach science education to preschool children were scored. Half of the teachers indicated they percieced they had a better ablity to teach science with their preschoolers. This leads me to conclude that the teachers who scored themselves as agreeing more with the question might not have understood what was being asked. 


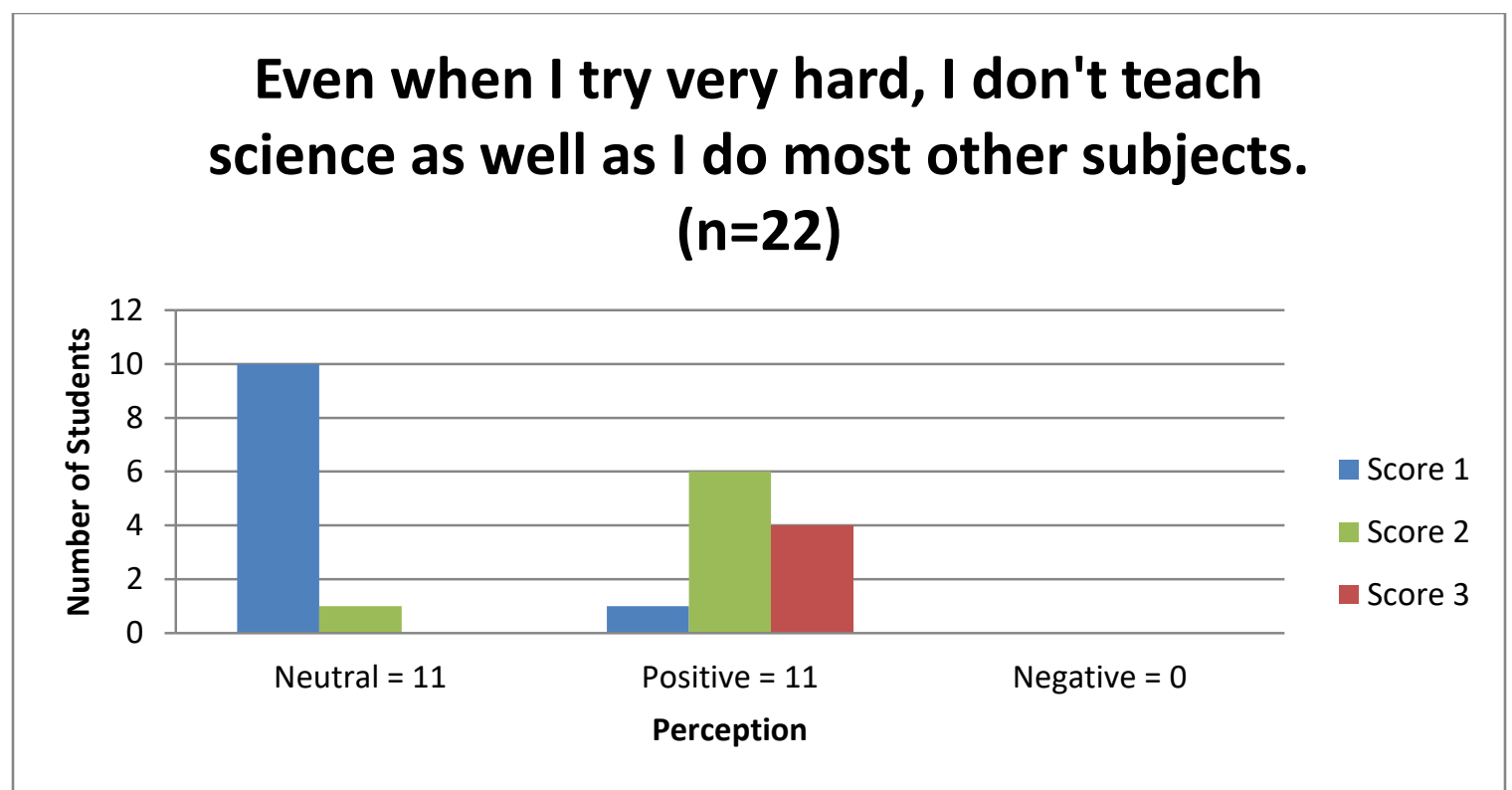

Figure 4b: Even when I try very hard, I don't teach science as well as I do most other subjects.-Comments

Figure 5a indicates that the teachers are less likely to agree with this statement, which is a positive response. The two teachers that answered they are more likely to agree with the statement, "I am not very effective in teaching/leading hands-on science projects.", both commented on feeling more confident teaching hands-on science projects. Student 14 commented, "Well that why I am taking classes like this one to improve my knowledge base and my skills. Every skill acquired need time and practice. The more you do it the better you get at it and the more questions you asked the more knowledge you gain." And Student 12a commented, "The class has taught me to ask question before/during/after the project . So I feel more comfortable now." In both cases the teacher indicated that the training improved her effectiveness teaching/leading handson science projects. 


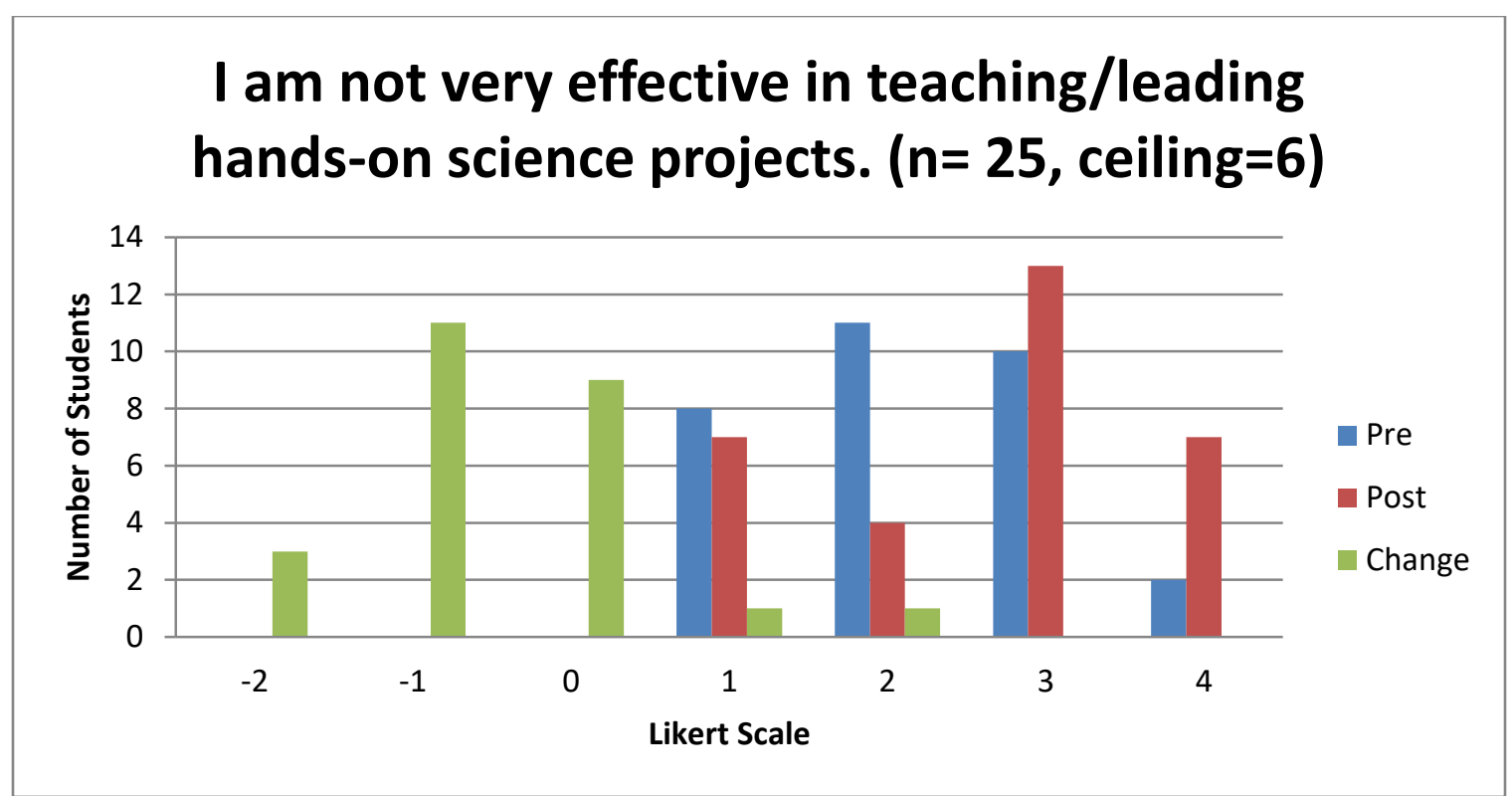

Figure 5a: I am not very effective in teaching/leading hands-on science projects. - Likert scale

\begin{tabular}{|l|l|}
\hline Result Details: I am not very effective in teaching/leading hands-on science projects. \\
\hline W-value & 21 \\
\hline Mean Difference & 2.31 \\
\hline Sum of Pos. Ranks & 21 \\
\hline Sum of Neg. Ranks & 115 \\
\hline Z-value & -2.4303 \\
\hline Mean (W) & 68 \\
\hline Standard Deviation (W) & 19.34 \\
\hline p-value at p $\leq 0.05$ & 0.0151 \\
\hline Sample Size (N) & 25 \\
\hline
\end{tabular}

Table 12: I am not very effective in teaching/leading hands-on science projects statistical analysis

In Figure $5 \mathrm{~b}$ almost half of the teachers indicated a percieved growth in their effectiveness teaching science with preschoolers. There was one teacher that had a precieved negative response to the question. She was one of the ELL teachers and commented, "Because my poor knoladge about science" 


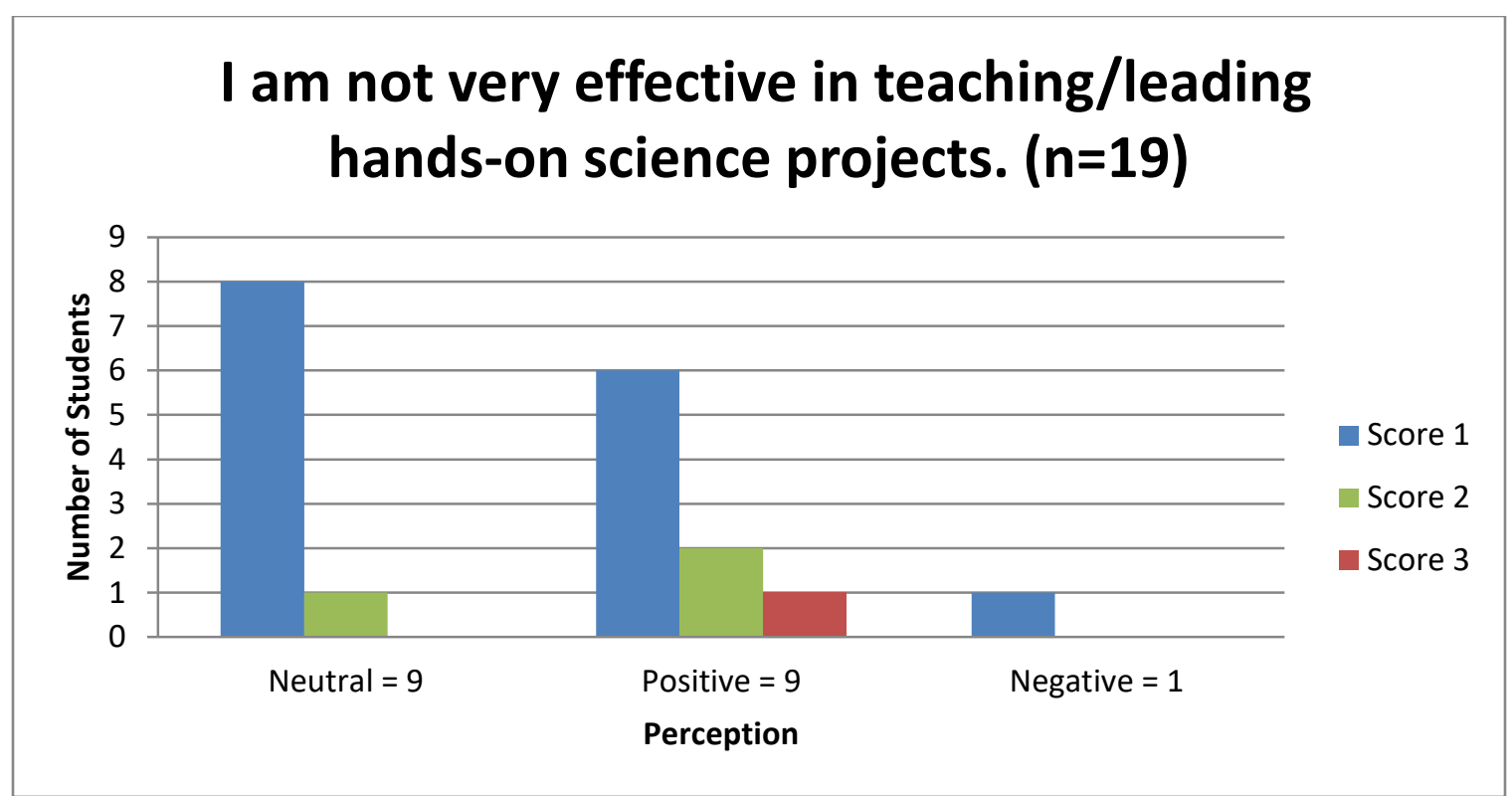

Figure 5b: I am not very effective in teaching/leading hands-on science projects. - Comments

Figure 6a shows that the teachers felt they better understood science concepts and were therefore more effective teaching science in a preschool program. The teacher that had a negative response commented in class about teachers needing to know all the answers. This training emphasized the concept that science in preschool is more about exploration for both the students and teachers than knowing and memorizing facts and figures. 


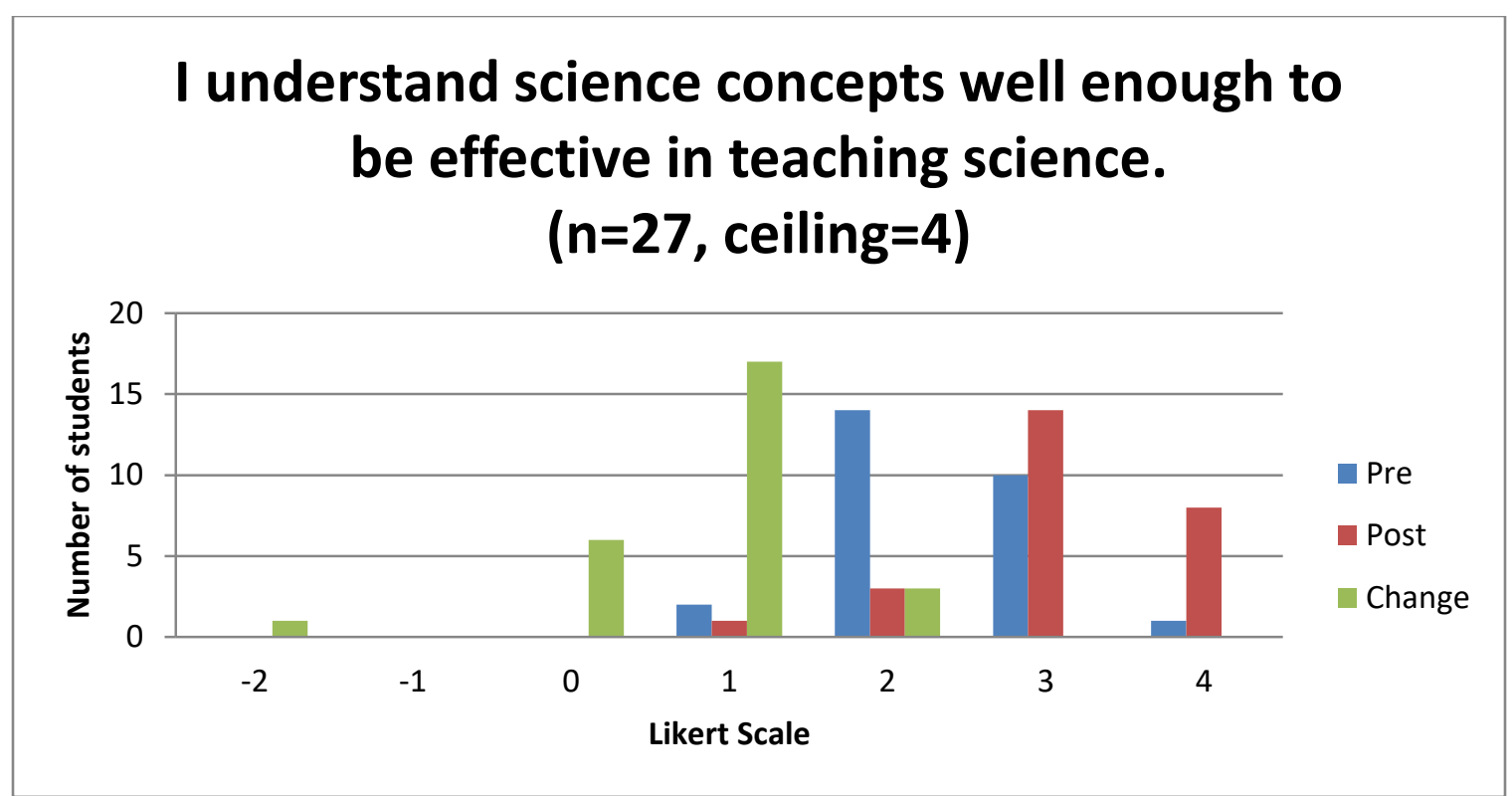

Figure 6a: I understand science concepts well enough to be effective in teaching science. - Likert scale

\begin{tabular}{|l|l|}
\hline Result Details: I understand science concepts well enough to be effective in teaching science. \\
\hline W-value & 19.5 \\
\hline Mean Difference & 2.33 \\
\hline Sum of Pos. Ranks & 19.5 \\
\hline Sum of Neg. Ranks & 211.5 \\
\hline Z-value & -3.3367 \\
\hline Mean (W) & 115.5 \\
\hline Standard Deviation (W) & 28.77 \\
\hline p-value at p $\leq 0.05$ & 0.00084 \\
\hline Sample Size $(\mathrm{N})$ & 27 \\
\hline
\end{tabular}

Table 13: I understand science concepts well enough to be effective ... statistical analysis.

Figure 6b supports the teachers' perception that they were more comfortable with science education after the training. As with Figure 6a there was one teacher that had a negative perception regarding her comfort. Based on her comment, "I feel like is a lot to teach with diferent ideas we share each other, but no enogh to feel confortable to teach with new english terms", it is the challenge of first feeling effective teaching in English. 


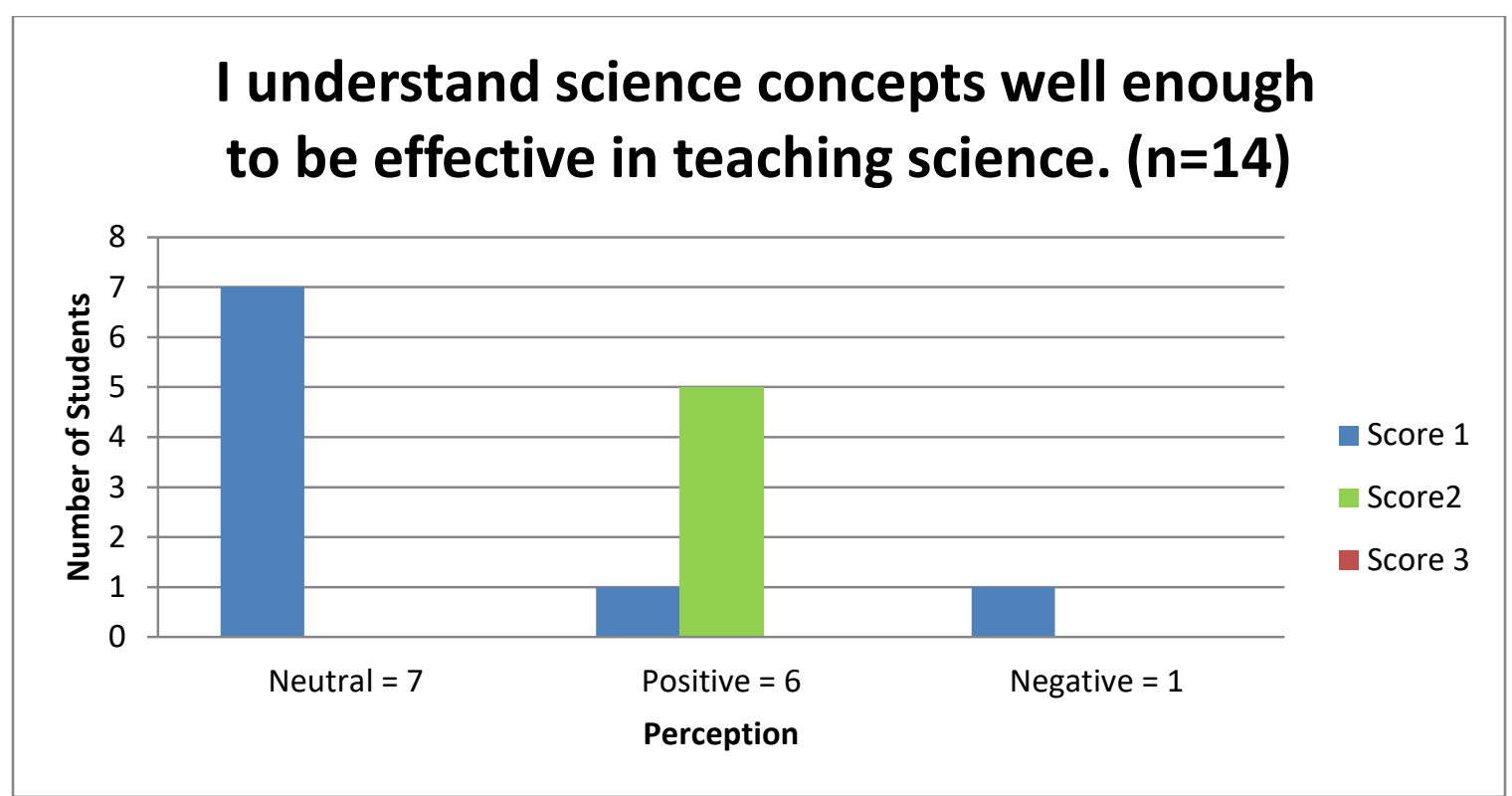

Figure 6b: I understand science concepts well enough to be effective in teaching science. - Comments

Figures $7 \mathrm{a}$ through $8 \mathrm{~b}$ show how teachers changed how they manage children asking questions in the classroom. The figures representing the teachers' comments, Figures $7 b \& 8 b$, indicate that the teachers perceive their ability to help children answer their own questions and be welcome to questions increased.

Figure 7a shows an increase in the number of teachers that welcome questions from students and work to help their students find the answer. Both teachers that had a perceived negative growth were ELL. One of them commented "helping it is through larning". The other teacher expressed the attitude that science in preschool should be for the "Wow effect". 


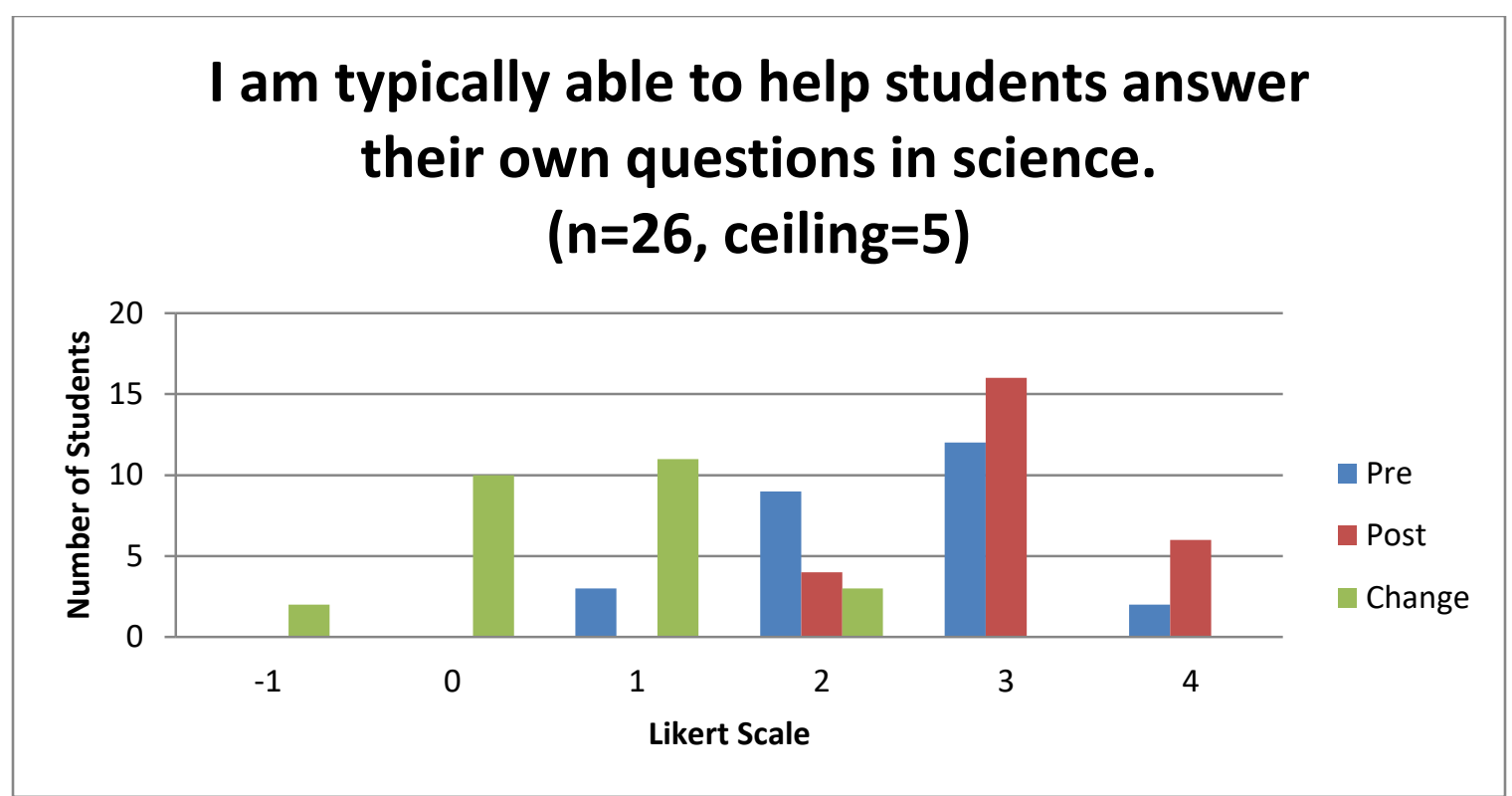

Figure 7a: I am typically able to help students answer their own questions in science. - Likert scale

\begin{tabular}{|l|l|}
\hline \multicolumn{2}{|l|}{ Result Details: I am typically able to help students answer their own questions in science. } \\
\hline W-value & 14 \\
\hline Mean Difference & 1.44 \\
\hline Sum of Pos. Ranks & 14 \\
\hline Sum of Neg. Ranks & 122 \\
\hline Z-value & -2.7923 \\
\hline Mean (W) & 68 \\
\hline Standard Deviation (W) & 19.34 \\
\hline p-value at p $\leq 0.05$ & 0.00528 \\
\hline Sample Size (N) & 16 \\
\hline
\end{tabular}

Table 14: I am typically able to help students answer their won questions in science statistical analysis

The one teacher in Figure $7 \mathrm{~b}$ that commented negatively regarding her ability to work with children's questions, was more concerned about the answer be "right", than the process of finding the answer. She stated, "I need to be more concerned about how to help them get the 'right' answer." 


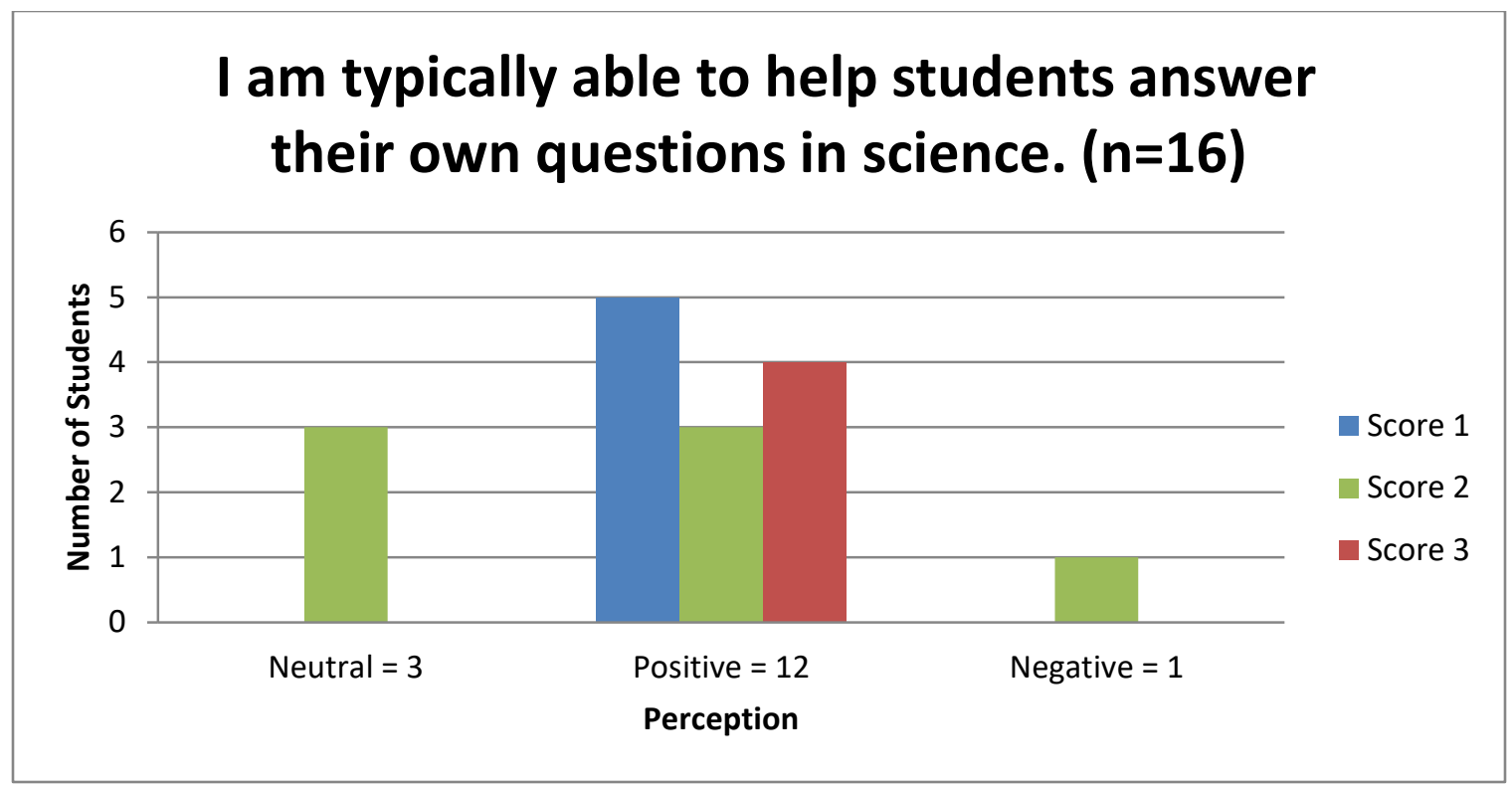

Figure 7b: I am typically able to help students answer their own questions in science. - Comments

Figure 8a drills down to an increase in the comfort level of the teachers regarding answering science based questions.

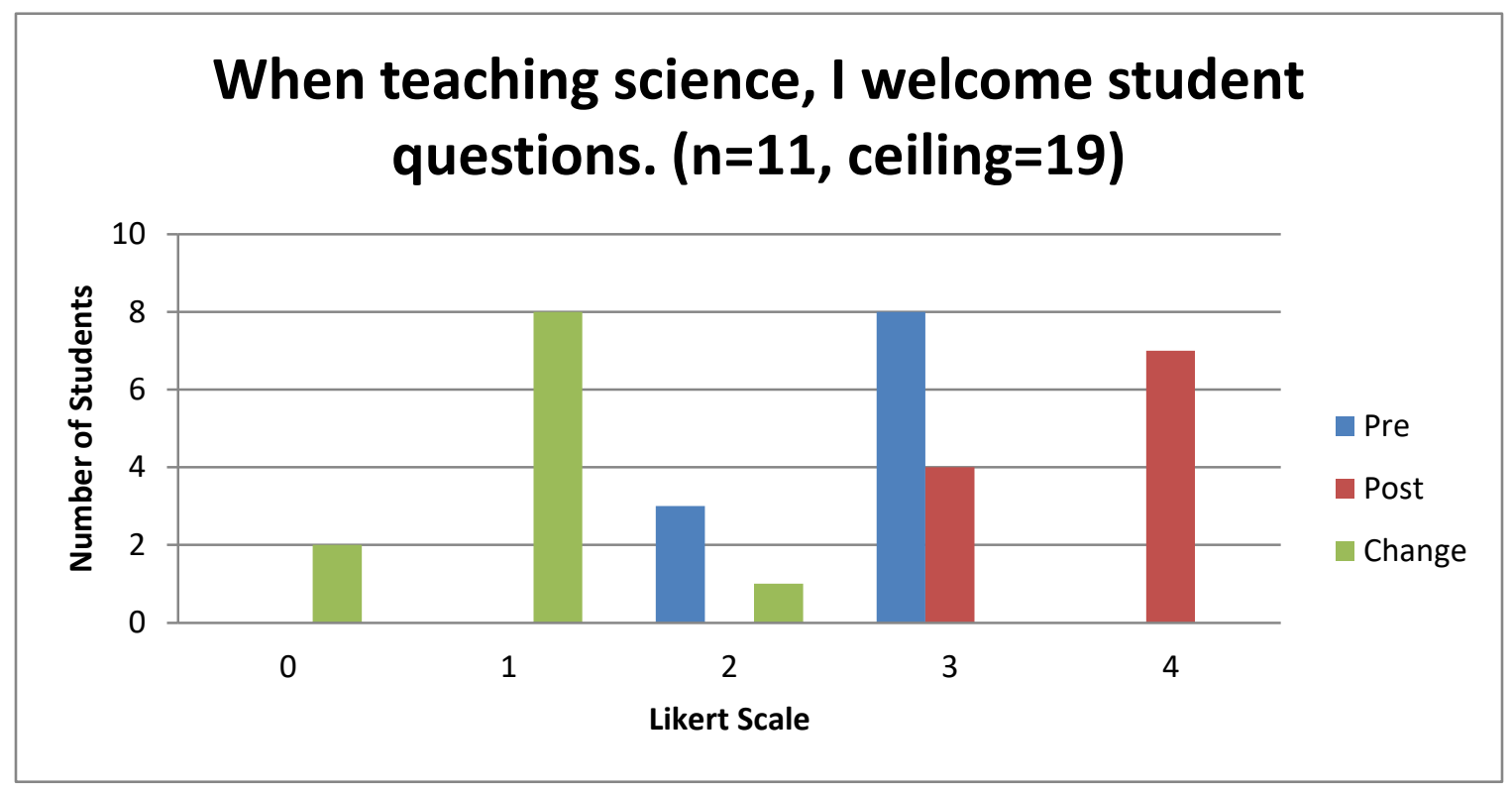

Figure 8a: When teaching science, I welcome student questions. - Likert scale 


\begin{tabular}{|l|l|}
\hline \multicolumn{2}{|l|}{ Result Details: When teaching science, I welcome student questions. } \\
\hline W-value & 0 \\
\hline Mean Difference & 1.3 \\
\hline Sum of Pos. Ranks & 0 \\
\hline Sum of Neg. Ranks & 55 \\
\hline Z-value & -2.8031 \\
\hline Mean (W) & 27.5 \\
\hline Standard Deviation (W) & 9.81 \\
\hline p-value at p $\leq 0.05$ & 0.00512 \\
\hline Sample Size $(\mathrm{N})$ & 11 \\
\hline
\end{tabular}

Table 15: When teaching science, I welcome student questions statistical analysis.

Figure $8 \mathrm{~b}$ shows that $94 \%$ of the teachers' comments indicated a positive growth regarding their perceived comfort with children asking questions.

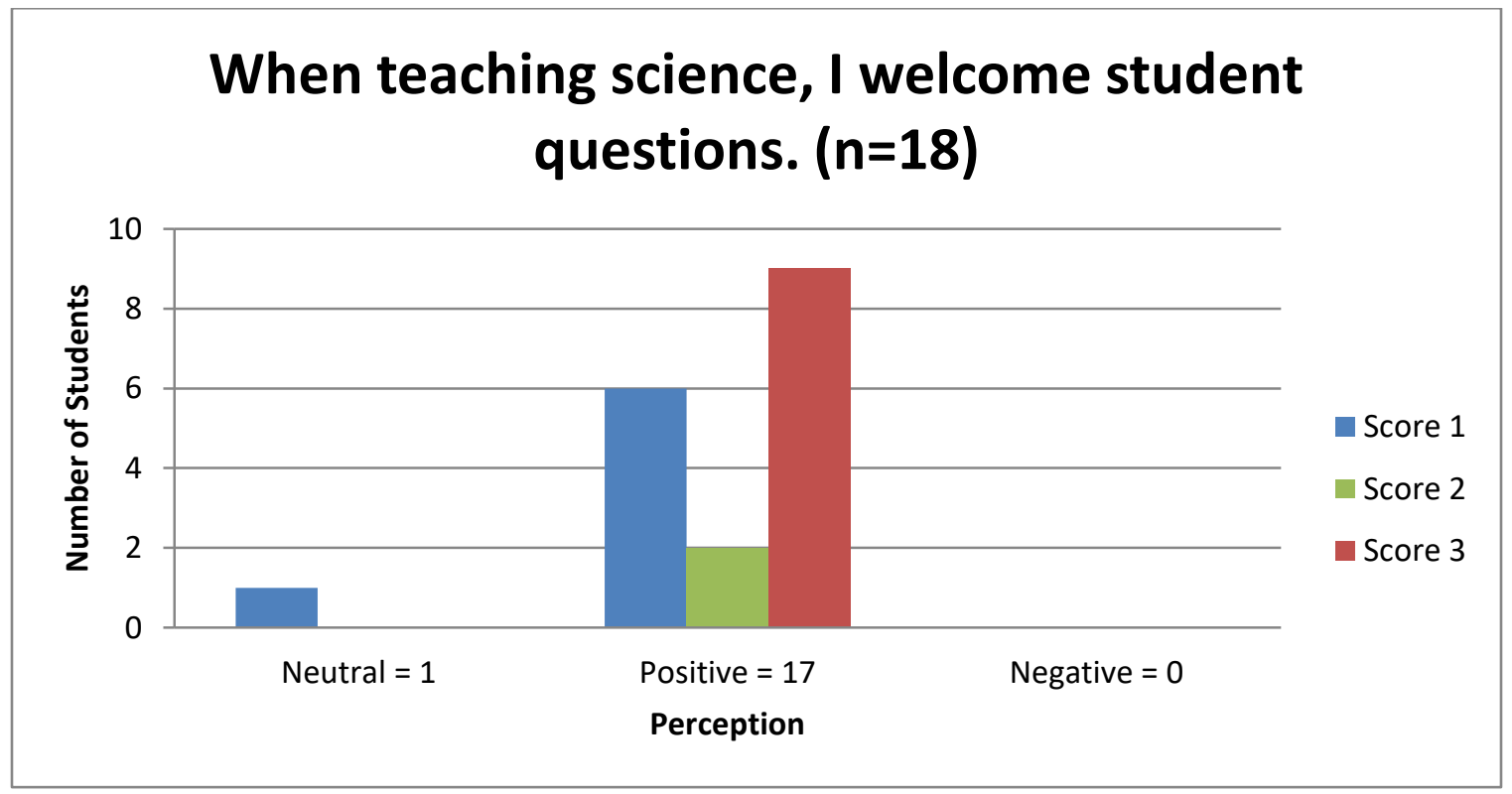

Figure 8b: When teaching science, I welcome student questions. - Comments

Figure $9 \mathrm{a}$ is one of the most significant regarding self-efficacy in science education. Of the twenty-four teachers that were not part of the ceiling effect, most of them indicated a positive shift toward feeling successful teaching hands-on science investigations with their children. The teacher that responded negatively was the same one that commented on science in preschool being for "Wow effect". 




Figure 9a: I have the necessary skills to teach hands-on/inquiry-based science. - Likert scale

\begin{tabular}{|c|c|}
\hline W-value & 7.5 \\
\hline Mean Difference & 1.65 \\
\hline Sum of Pos. Ranks & 7.5 \\
\hline Sum of Neg. Ranks & 145.5 \\
\hline Z-value & -3.2663 \\
\hline Mean $(W)$ & 76.5 \\
\hline Standard Deviation (W) & 21.12 \\
\hline$p$-value at $p \leq 0.05$ & 0.00108 \\
\hline$\overline{\text { Sample Size (N) }}$ & 24 \\
\hline
\end{tabular}

The comments graphed in Figure 9b support the teachers' perception of

increasing their skills regarding science education in the preschool classroom. Over $85 \%$ of the teachers commented on a positive growth regarding their understanding of the nature of science and science practices as they relate to preschool students. 


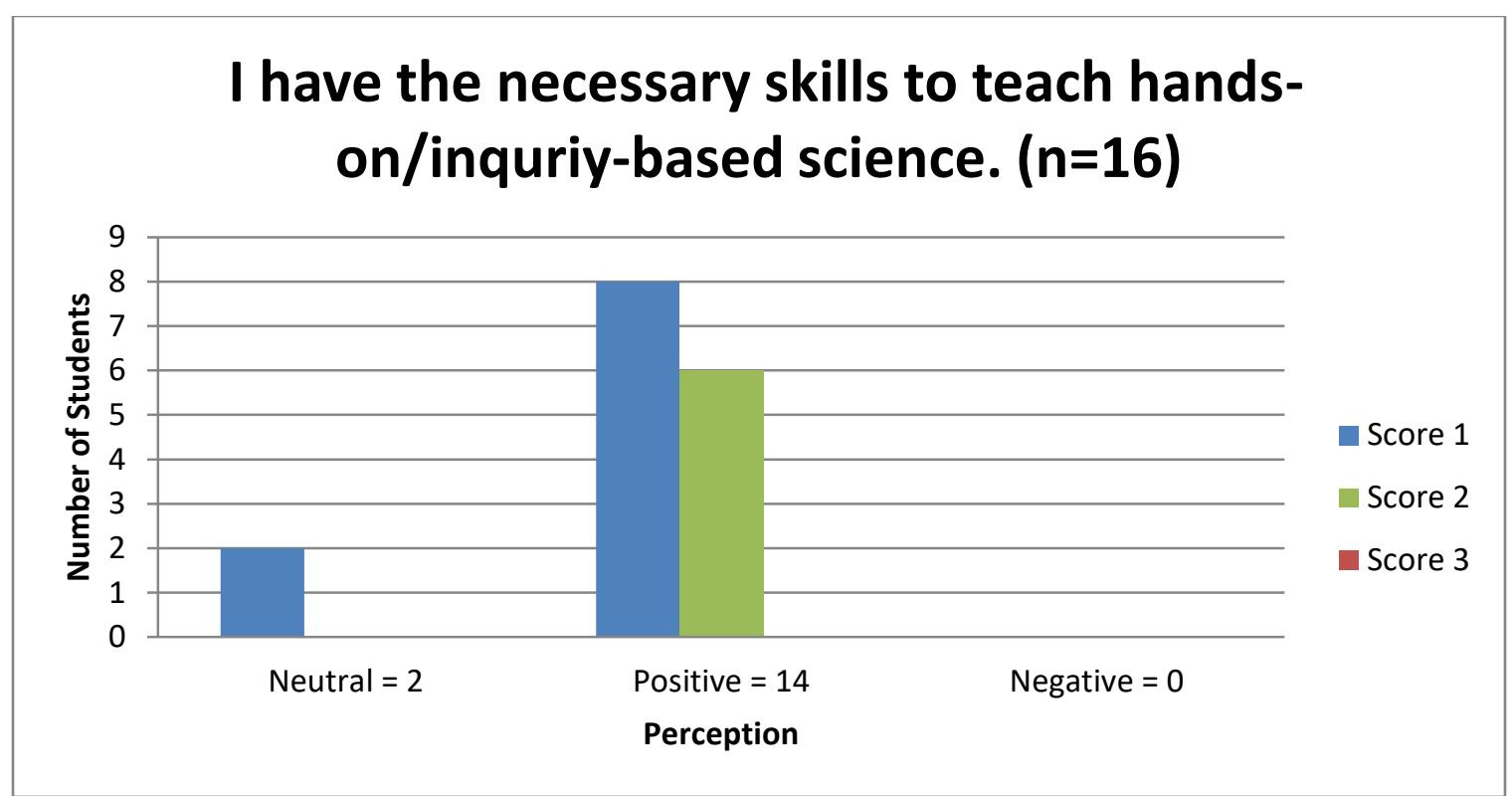

Figure 9b: I have the necessary skills to teach hands-on/inquiry-based science. - Comments

The p-values shown in Tables 12-16 indicate significance in the data as they are less than 0.05 . Table 11 shows that the p-value is greater than 0.05 indicating the data has limited significance.

\section{Understanding of the Nature of Science and Science Inquiry}

To effectively teach science, the teachers need to understand science as a practice and a way of understanding the world around them. As one teacher stated "I thought science was only like magic.” And as Andersson and Gullburg (2012) state for many preschool teachers science is relegated to watching butterflies develop from caterpillars and growing a seed. Figures $10 \mathrm{a}-15 \mathrm{~b}$ demonstrate how the teachers grew in their understanding of the nature of science.

Figure 10a shows less than half of the teachers that were not part of the ceiling effect increased their agreement that they can teach with the understanding that scientific knowledge is open to revision. Of the teachers that indicated they agreed more with the statement than when they started two did not have any comments. One of the teachers 
that indicated she agreed more with the statement than when she started commented "yes all children".

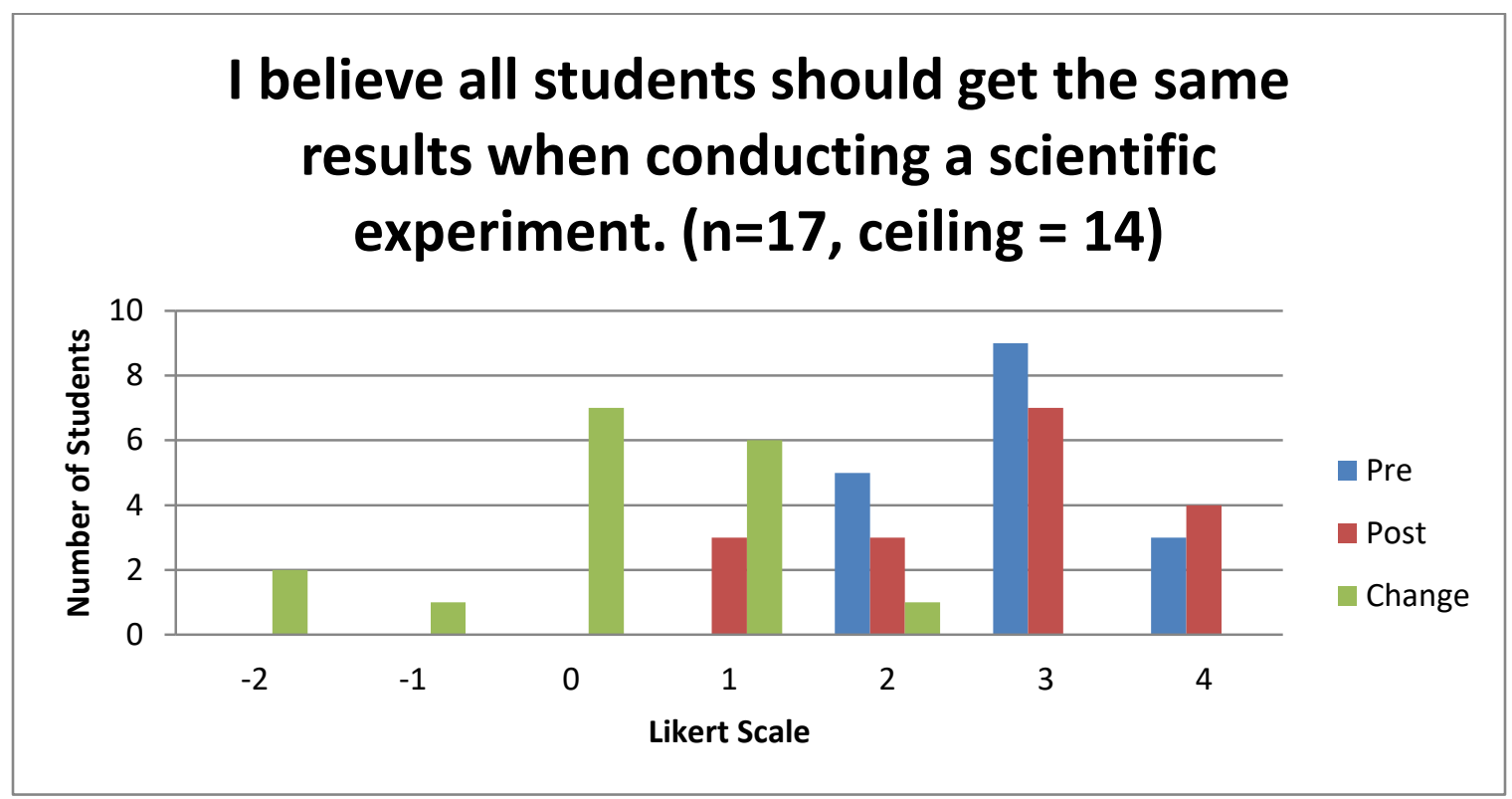

Figure 10a: I believe all students should get the same results ... - Likert scale

\begin{tabular}{|l|l|}
\hline \multicolumn{2}{|l|}{ Result Details: I believe all students should get the same results... } \\
\hline W-value & 22 \\
\hline Mean Difference & 3.2 \\
\hline Sum of Pos. Ranks & 33 \\
\hline Sum of Neg. Ranks & 22 \\
\hline Z-value & -0.5606 \\
\hline Mean (W) & 27.5 \\
\hline Standard Deviation (W) & 9.81 \\
\hline p-value at p $\leq 0.05$ & 0.57548 \\
\hline Sample Size $(\mathrm{N})$ & 17 \\
\hline
\end{tabular}

Table 17: I believe all students should get the same results... statistical analysis

The data shown in Figure 10b indicates that there were more teachers that increased the perceived understanding of the nature of science matrix science is a way of knowing and a human endeavor and the science practice of analyzing and interpreting data (NGSS Lead States, 2013). 




Figure 10b: I believe all students should get the same results ...-Comments

Figure 11a shows a shift in the idea that scientific knowledge is open to revision based on new evidence. Figure 11a shows how the teachers have developed an understanding of how science facts can change and that just knowing the facts is not the best way to learn about the nature of science and science inquiry. Most of the teachers showed a positive change toward understanding where science knowledge comes from.



Figure 11a: I believe scientific theories can change based on new evidence. - Likert scale 


\begin{tabular}{|l|l|}
\hline \multicolumn{2}{|l|}{ Result Details: I believe scientific theories can change based on new evidence. } \\
\hline W-value & 0 \\
\hline Mean Difference & 0.69 \\
\hline Sum of Pos. Ranks & 0 \\
\hline Sum of Neg. Ranks & 91 \\
\hline Z-value & -3.1798 \\
\hline Mean (W) & 45.5 \\
\hline Standard Deviation (W) & 14.31 \\
\hline p-value at p $\leq 0.05$ & 0.00148 \\
\hline \hline Sample Size $(\mathrm{N})$ & 17 \\
\hline
\end{tabular}

Table 18: I believe scientific theories can change based on new evidence statistical analysis.

Figure $11 \mathrm{~b}$ shows eleven teachers, of the fifteen who commented, perceived better understanding of the nature of science construct scientific knowledge is open to revision in light of new evidence (NGSS Lead States, 2013). The one teacher that responded negatively was one of the ELL teachers and stated, "depends on the age grup".



Figure 11b: I believe scientific theories can change based on new evidence. - Comments

The concept shown in figures $12 \mathrm{a} \& \mathrm{~b}$ started with most of the teachers already agreeing with the statement, with a ceiling effect of twenty-one. Most teachers that changed their view changed toward the positive.

Figure 12a demonstrates the teachers understanding that science is a way of 
knowing and about problem solving instead of learning facts. Figure 12a shows an increase in the number of teachers that understand that asking and answering questions are part of problem solving. There were two teachers that scored negatively on this survey. For one of the teachers English is a second language. The other teacher wrote "It's more important to let them lead their own investigation".



Figure 12a: I believe it is my job to foster student problem solving. - Likert scale

\begin{tabular}{|l|l|}
\hline Result Details: I believe it is my job to foster student problem solving. \\
\hline W-value & 7 \\
\hline Mean Difference & 2.43 \\
\hline Sum of Pos. Ranks & 7 \\
\hline Sum of Neg. Ranks & 21 \\
\hline Z-value & -1.1832 \\
\hline Mean (W) & - \\
\hline Standard Deviation (W) & - \\
\hline p-value at p $\leq 0.05$ & - \\
\hline Sample Size (N) & 10 \\
\hline & Table 19: I believe it is my job to foster student problem solving statistical analysis.
\end{tabular}

Figure $12 \mathrm{~b}$ indicates that the teachers' comments support the increased perception of ability to engage preschool children in problem solving. 


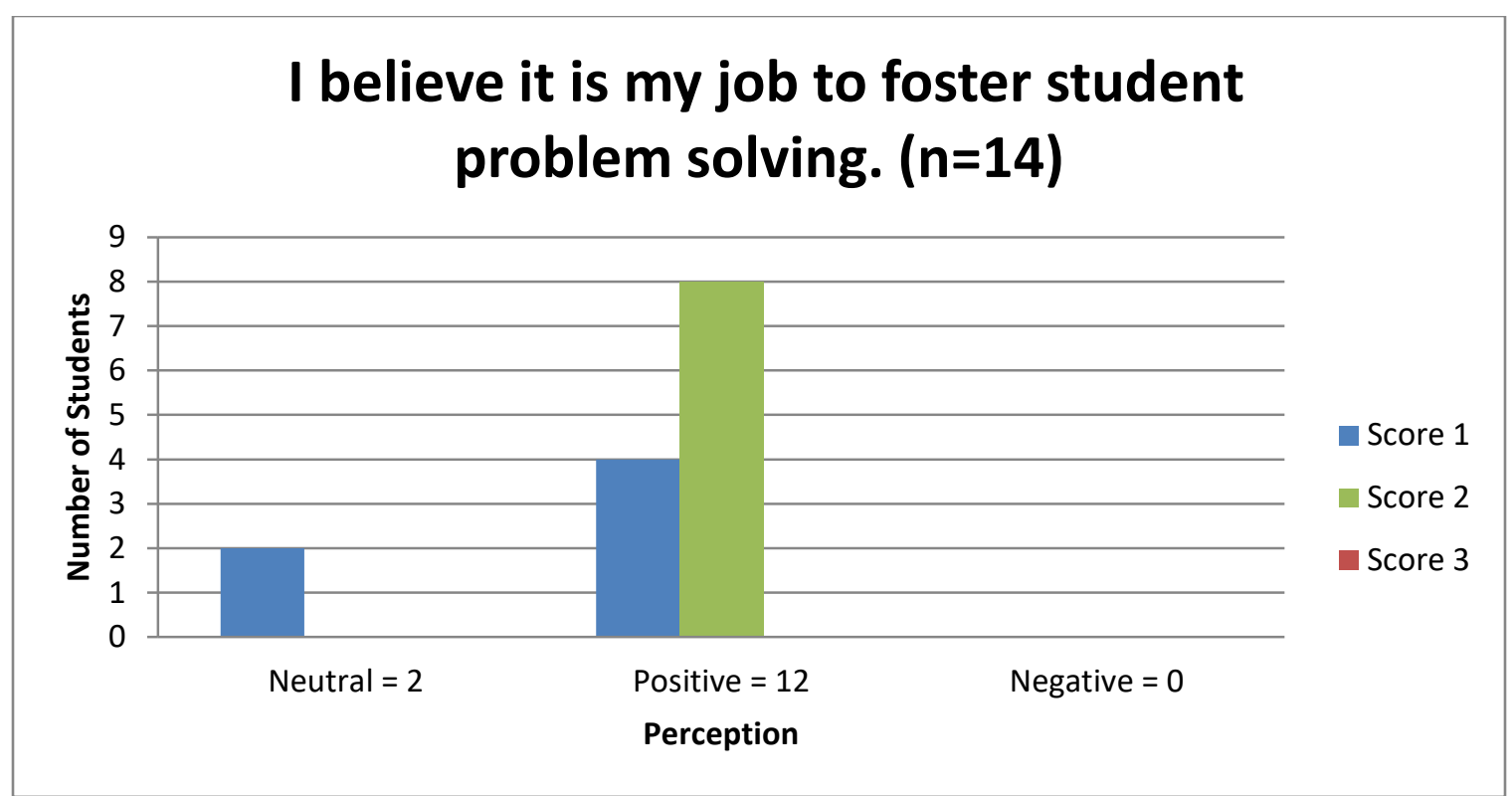

Figure 12b: I believe it is my job to foster student problem solving. - Comments

Figure 13a is focused on how the teacher can be comfortable with not having all the answers and recognizing that science is a human endeavor. Figure 13a not only shows that the teachers are learning how to use the nature of science and science inquiry, but they are becoming comfortable with it. Almost a third of the teachers in the training feel that they understand the nature of science and science inquiry well enough to use these skills to find out how the world works. 


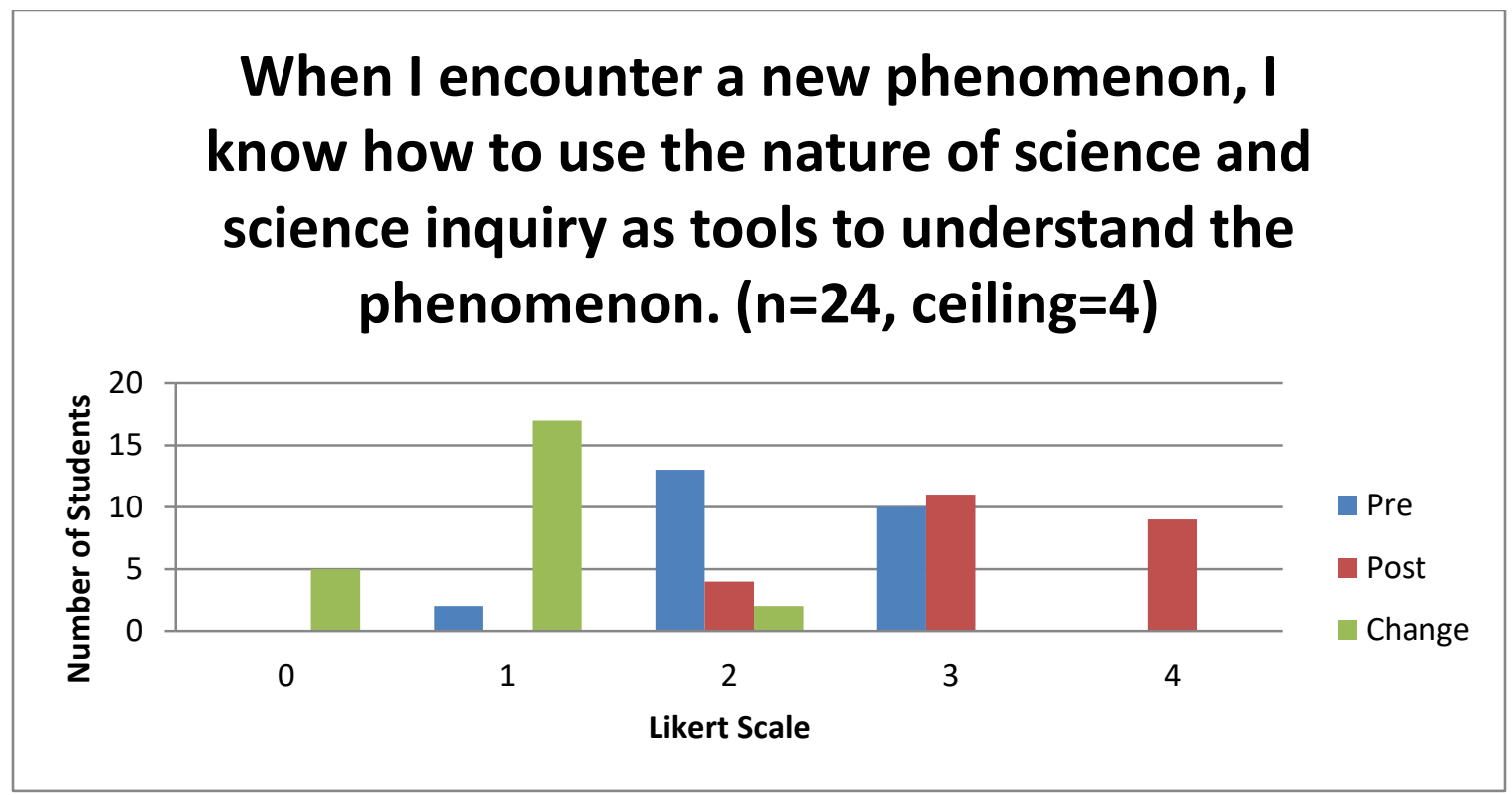

Figure 13a: When I encounter a new phenomenon, I know how to use the nature of science... - Likert scale

\begin{tabular}{|l|l|}
\hline $\begin{array}{l}\text { Result Details: When I encounter a new phenomenon, I know how to use the } \\
\text { nature of science and science inquiry as tools to understand the phenomenon. }\end{array}$ \\
\hline W-value & 0 \\
\hline Mean Difference & 0.84 \\
\hline Sum of Pos. Ranks & 0 \\
\hline Sum of Neg. Ranks & 190 \\
\hline Z-value & -3.823 \\
\hline Mean (W) & 95 \\
\hline Standard Deviation $(\mathrm{W})$ & 24.85 \\
\hline p-value at p $\leq 0.05$ & 0.00014 \\
\hline Sample Size $(\mathrm{N})$ & 24 \\
\hline
\end{tabular}

Table 20: When I encounter a new phenomenon... statistical analysis

Figure $13 \mathrm{~b}$ demonstrates the number of teachers whose comments indicated a perceived increase in understanding how science works. Almost three-quarters of the teachers indicated they could use science practices and the nature of science to understand how the world works. 


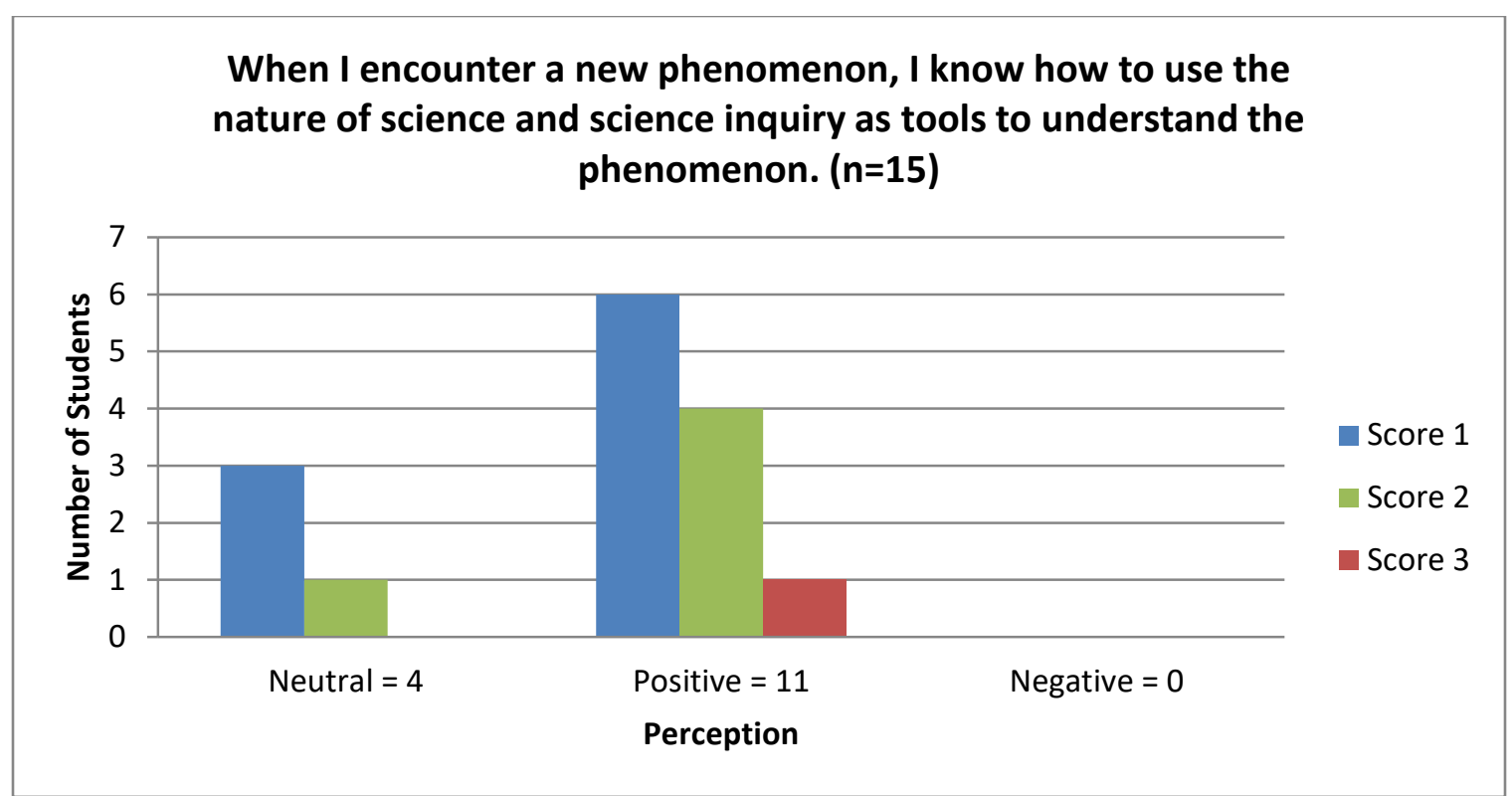

Figure 13b: When I encounter a new phenomenon, I know how to use the nature of science... - Comments

Figure $14 \mathrm{a}$ addresses the teachers understanding that science addresses questions about the natural and material world and that specialized equipment is not necessary for preschool students to figure out how the world works because scientific investigations use a variety of methods. By being able to use the materials around them, including their senses, science inquiry becomes less difficult and time consuming. Almost half of the class shows an understanding that everyday items can be used to teach science according to Figure 14a. The one teacher that had a negative response is confusing since she used a comparison of apples, everyday objects, as her science lesson. 


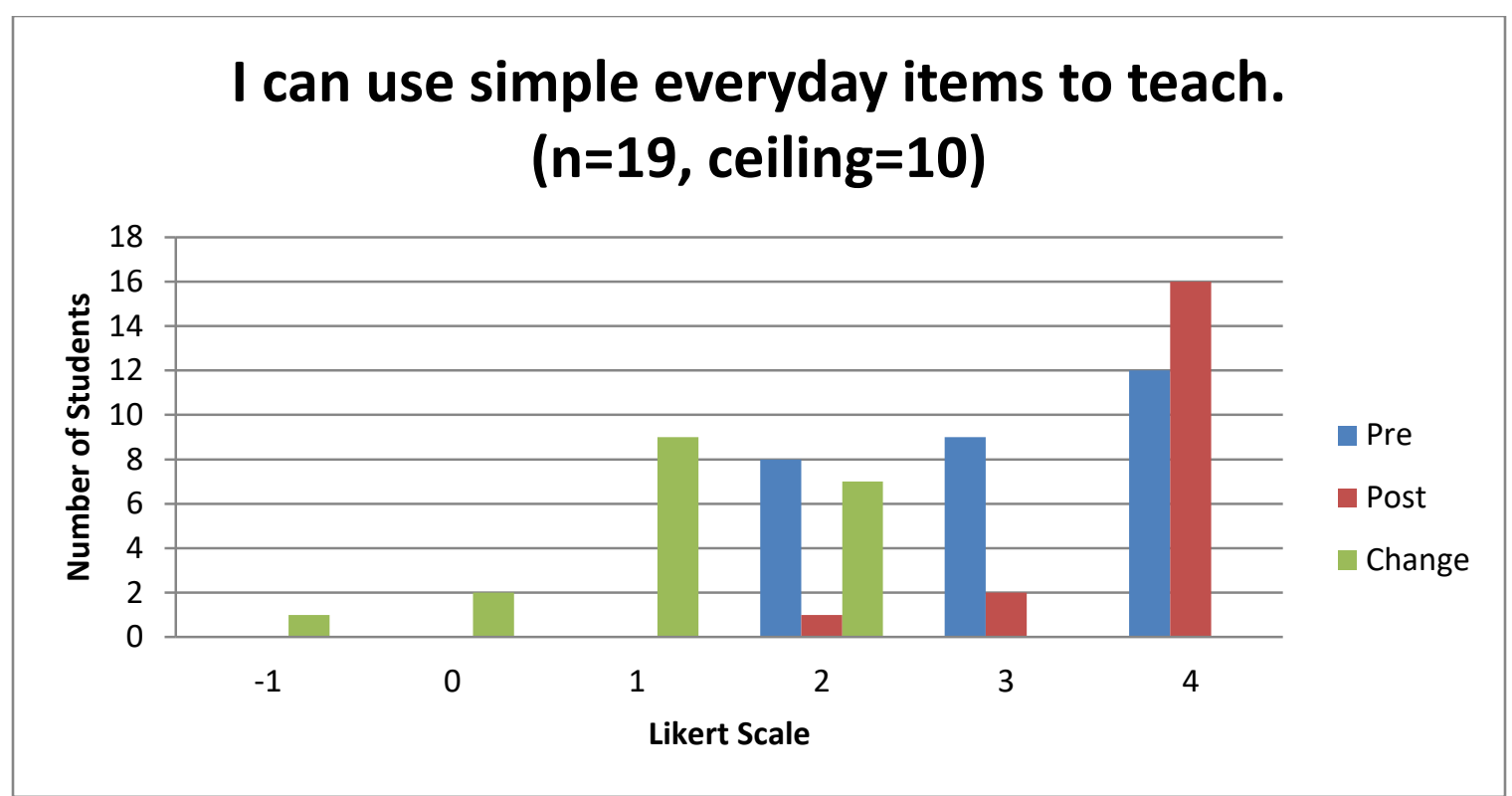

Figure 14a: I can use simple everyday items to teach science. - Likert scale

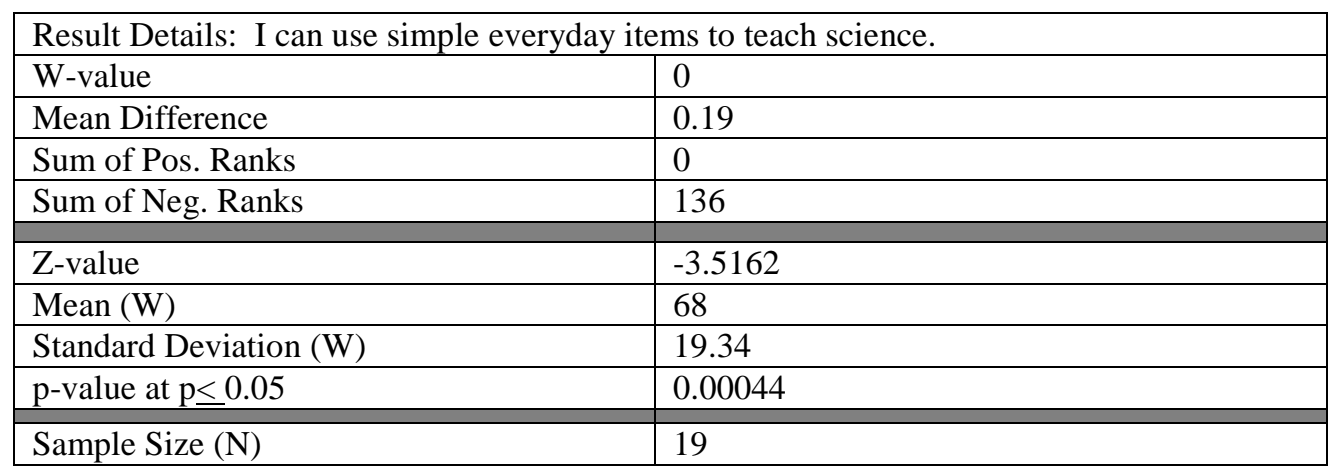

Table 21: I can use simple everyday items to teach science statistical analysis.

Figure $14 \mathrm{~b}$ also demonstrates that there is a large percentage of teachers that commented positively about their perceived ability to use the materials they have on hand. 




Figure 14b: I can use simple everyday items to teach science. - Comments

Figures $15 \mathrm{a} \& \mathrm{~b}$ demonstrate how the teachers perceive the nature of science component of scientific investigations using a variety of methods. Figure 15a shows data regarding how teachers feel about flexability in teaching science. Figure 15a demonstrates that the teachers that were not part of the ceiling effect were close to evenly divided regarding their perceptions.

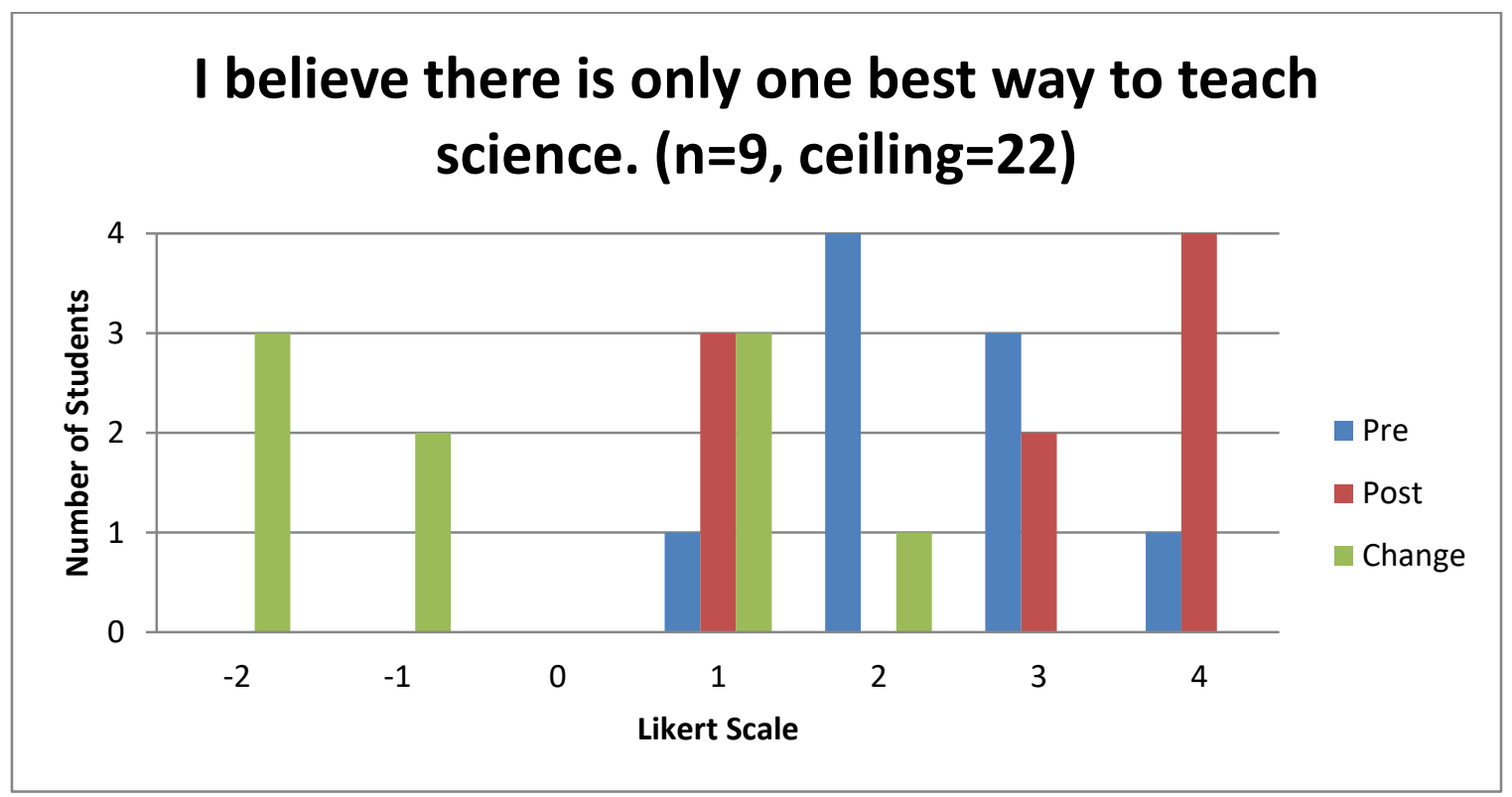

Figure 15a: I believe there is only one best way to teach science. - Likert scale 


\begin{tabular}{|l|l|}
\hline \multicolumn{2}{|l|}{ Result Details: I believe there is only one best way to teach science. } \\
\hline W-value & 16.5 \\
\hline Mean Difference & 1.44 \\
\hline Sum of Pos. Ranks & 16.5 \\
\hline Sum of Neg. Ranks & 28.5 \\
\hline Z-value & -0.7108 \\
\hline Mean (W) & - \\
\hline Standard Deviation $(\mathrm{W})$ & - \\
\hline p-value at p $\leq 0.05$ & - \\
\hline Sample Size $(\mathrm{N})$ & 9 \\
\hline
\end{tabular}

Table 22: I believe there is only one best way to teach science statistical analysis.

Figure $15 \mathrm{~b}$ shows that the comments from the teachers mostly indicated a positive perception of their understanding of scientific investigations use a variety of methods.

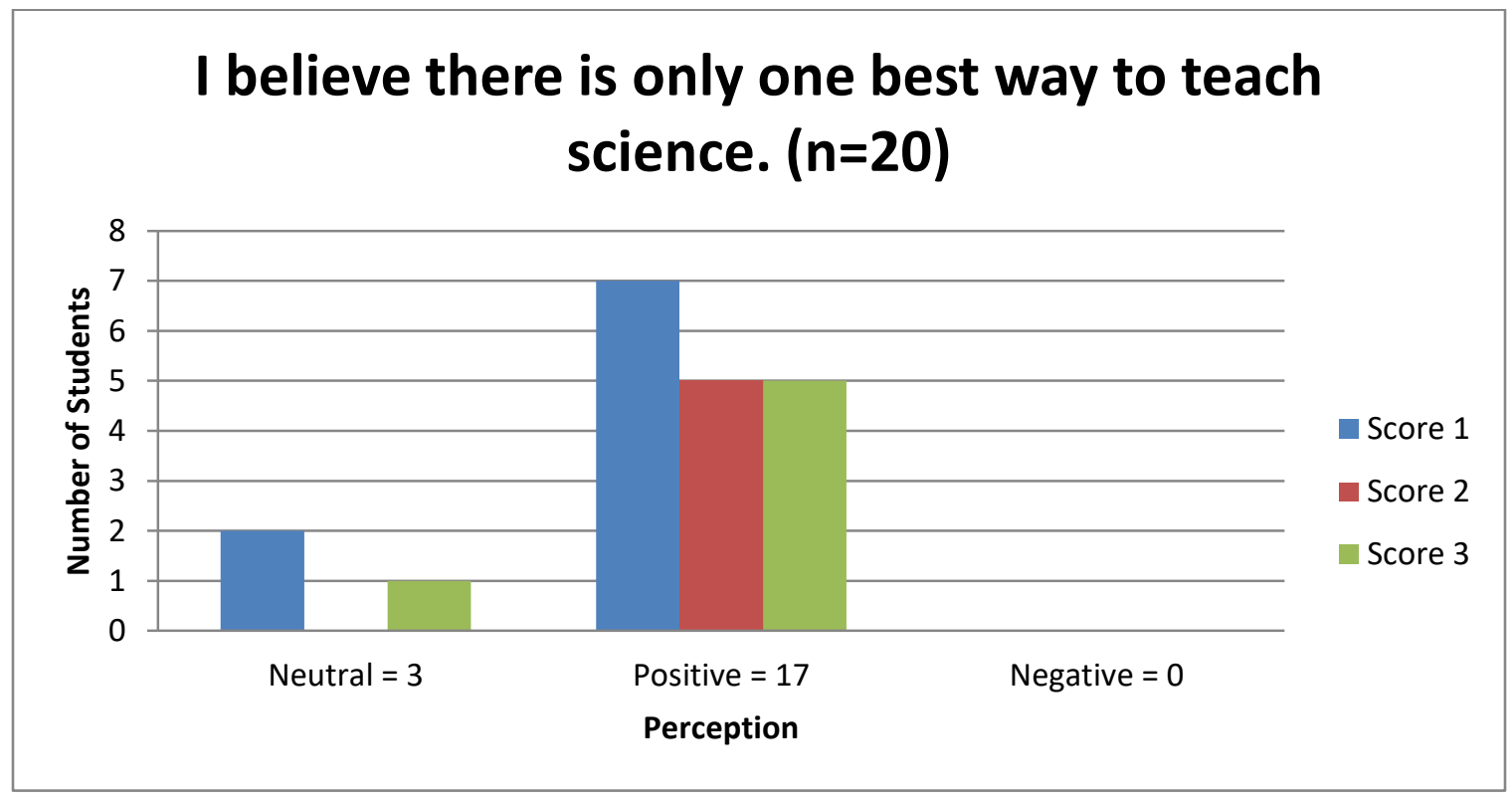

Figure 15b: I believe there is only one best way to teach science. - Comments

Tables 18, 20, and 21 show a p-value less than 0.05 indicating significance in the results. Table 17 shows a p-value greater than 0.05 limiting the significance of the data. The sample sizes after removal of the ceiling effect in questions 12 and 15 did not allow for an accurate p-value to be calculated as show in Tables 19 and 22. 


\section{Student Lesson Plans}

Another tool used to determine how the teachers were understanding the nature of science and science practices in preschool education was the lesson plan template. This tool also allowed the teachers to be evaluated for their ability to integrate Mind in the Making to science education.

Thirty of the teachers turned in their lesson plans. The lesson plans were evaluated for ability to connect the lesson to a big idea in science, connect science practices to the five "E's" of science inquiry (engage, explore, explain, elaborate, evaluate), Mind in the Making to the five "E's", and the teachers understanding of the nature of science. Below are Figures 16 - 19 reflecting the results of the scoring.

The scoring for Figure 16 was 1) the teacher made an attemp at a science lesson, 2) the teacher wrote a science lesson that worked with science inquiry and a science concept but the two did not match, and 3) the science inquiry and science concept that the teacher included matched and worked together. Of the thirty teachers that did the lesson seventeen used hands-on science inquiry. Nine of the seventeen were able to connect their lesson plan to a big idea (concept) in science, as seen in Figure 16. 


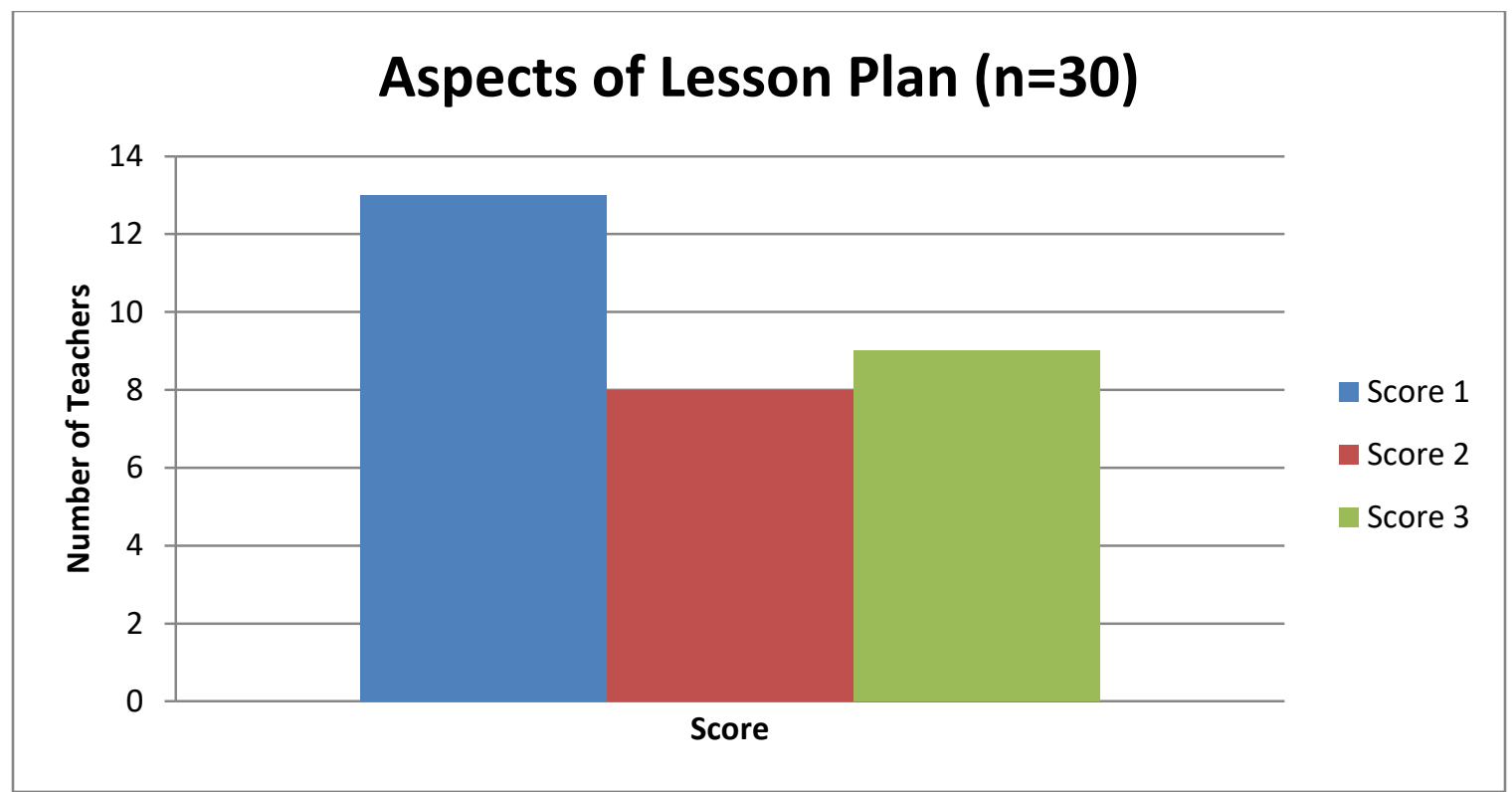

Figure 16: Aspects of Lesson Plan

For Figure 17 to score a 2 the teacher needed to be able to identify the science practice that went with the part of the activity they were discribing. If nothing was written in this area or a discription of the science activity was written in this area the score was a 1. Except for the "Evaluate" section, the teachers were able to connect the science practice to the focus point of the lesson plan.

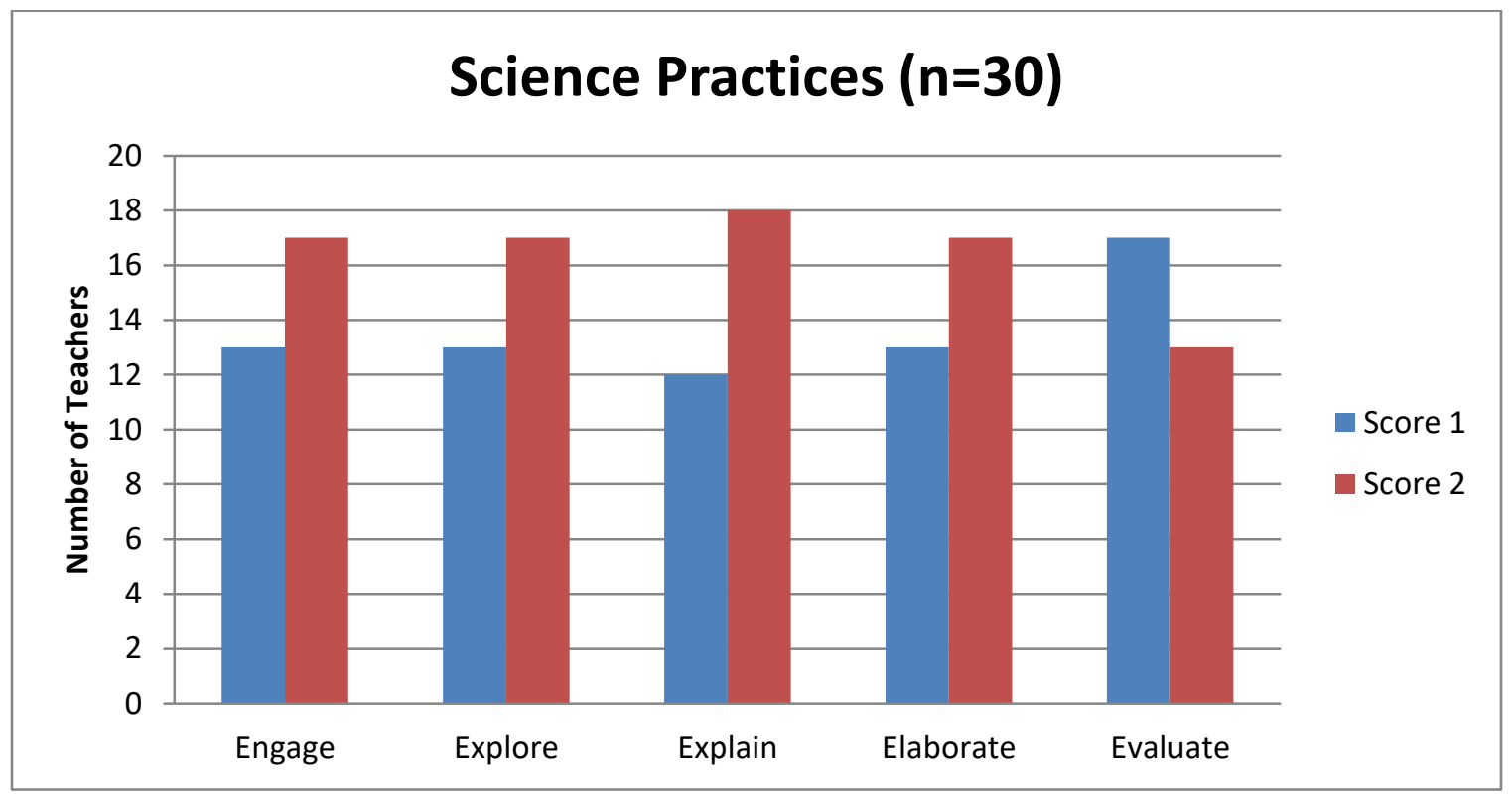

Figure 17: Science Practices 
For Figure 18, similar to Figure 17, in order to score a 2 the teacher needed to identify the correct Mind in the Making skill set that went with the part of the science inquiry. If the teacher did not write anything in the square or wrote what they were doing with the children for this section the score was a 1. Figure 18 indicates that the teachers were able to successfully connect the Mind in the Making skills set with the individual focus point of the lesson.

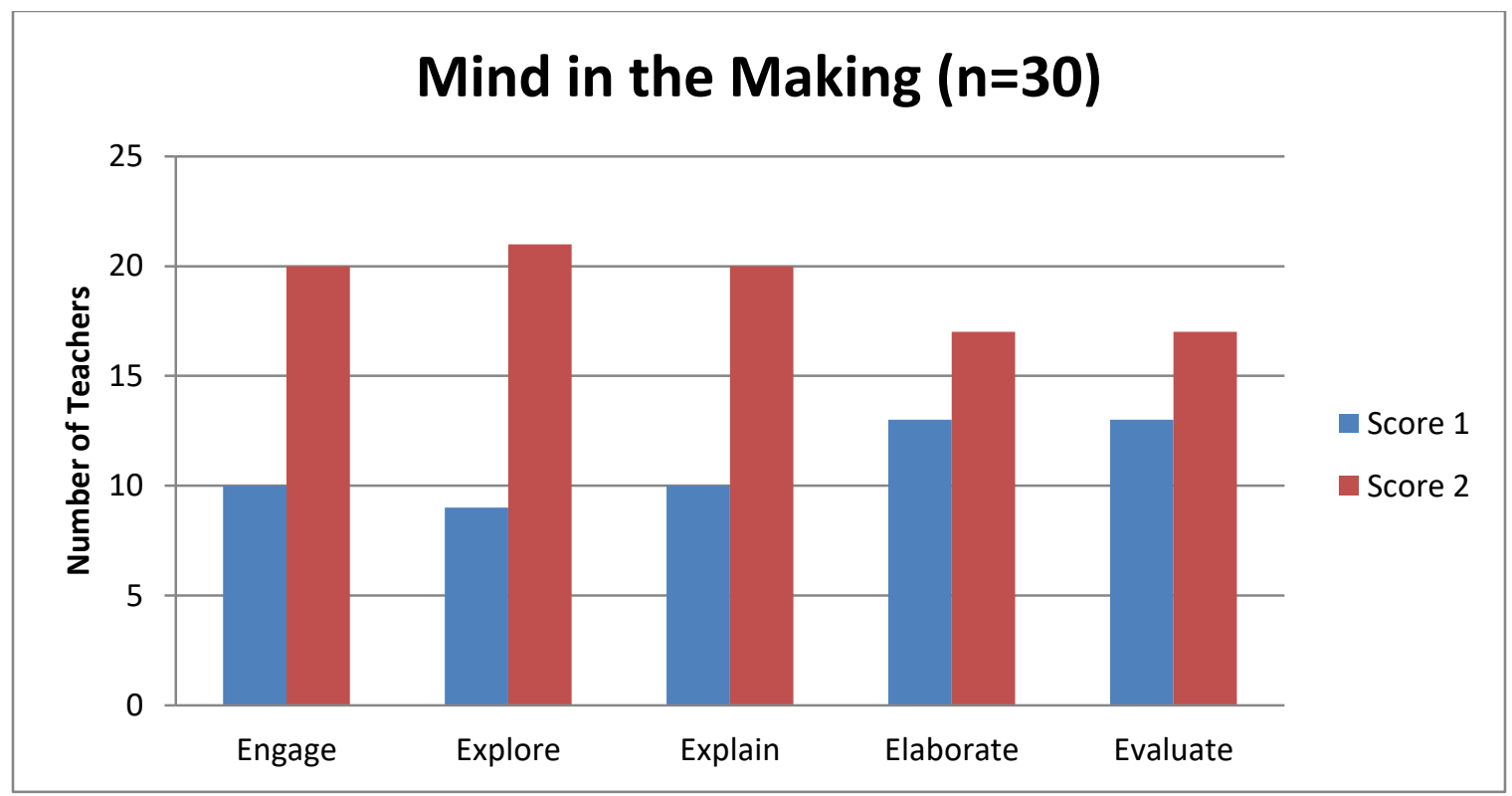

Figure 18: Mind in the Making

After the lesson plan was written out, there was a section that addressed how the activity would help the teacher's students understand science. The answers in this section were evaluated using a three point scale. To earn a 1) the teacher just needed to write something in the box. For a 2) the teacher needed to show how the activity is related to science. A score of 3) was for the answers that connected the activity to the nature of science and science inquiry. Of the thirty teachers that did the lesson plan eighteen were abel to relate their activity to understanding science. Five of those eighteen teachers could relate the activity to the nature of science and science inquriry. This can be seen in Figure 19. 


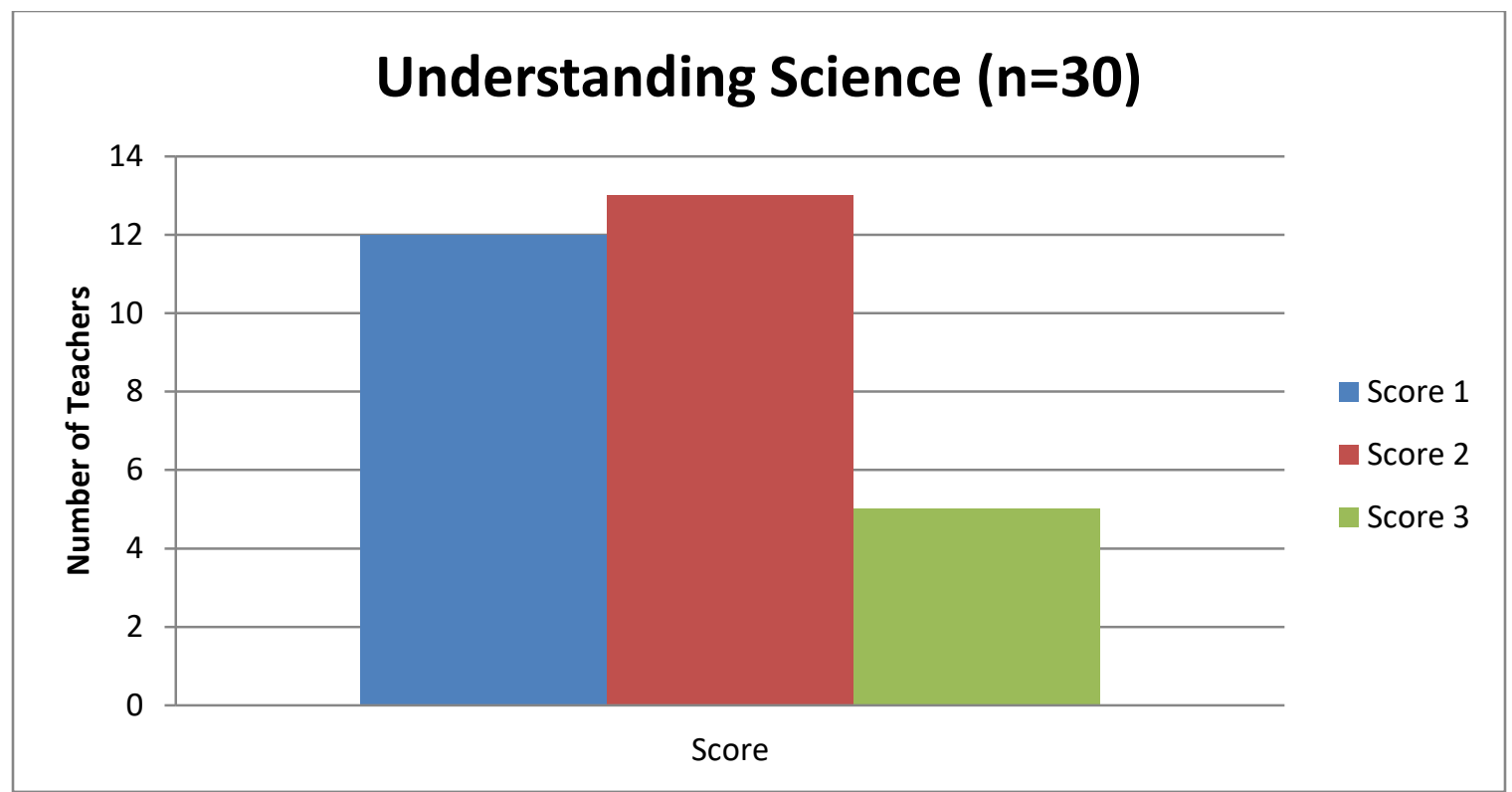

Figure 19: Understanding Science

Three examples of the lesson plans that showed an understanding of how to develop and carry out a science investigation are presented below. These examples showed a high level when connecting the lesson plan to the big idea in science and connecting the lesson plan to an stronger understanding of the nature of science and science practices.

Student 1 used a ballon rocket to introduce her students to force and motion. She connected her lesson plan to the big idea by stating, "When my students do this balloon rocket experiment they will be able to understand that the air coming out of the balloon [action] (force) causes the balloon to have an equal and opposite [reaction](motion)." She connected her lesson plan to the nature of science and science practices by "... help(ing) my students understand what science is by walking them through scientific steps of asking questions, guessing what will happen, testing out their ideas through experiments, observing then evaluationg the outcome(s). These tools wil help them learn about the world around them - science." 
Student 4a "Demonstrated air as a gas" (matter). Her connection to the big idea in science was "That it can be possible to change the properties of a bag by adding air gas." Specifically, she threw an empty bag in the air and had her children watch it come down. The she filled the bag with air and threw it in the air and had the children watch it come down and notice the difference. As she worked with one-year-olds her connection to the nature of science and science practices is simple "It will help them be curious and wonder what makes things happen.”

The title of Student 12's lesson plan is "Gravity... The science of falling down" Her essential question is "Does gravity affect jumping distance? in motion $\mathrm{x}$ incline/height" Her connection to the nature of science and science practices is "This activity reflects the steps of questioning, experimenation, data collection and hypothosises. I easily demonstrates the steps to the discovery of the natural order of life."

Based on the comments and the survey answers the teachers improved their understanding of the nature of science and science practices as they relate to Mind in the Making life skills as well as their self-efficacy when teaching hands-on science inquiry with their students. The teachers' understanding of the nature of science and science practices, as they relate to Mind in the Making life skills, improved. Their self-efficacy when teaching hands-on science inquiry with their students, also, improved Information gained through analysis of their lesson plansreinforced these conclutions. 


\section{Discussion}

The focus of this research is improving teachers' self-efficacy regarding science education, thus increasing the likelihood that science will be included in early childhood education. In order to accomplish this, preschool teachers must overcome their perception that science is overly complicated and should be separate from everything else that is done in the classroom (Brenneman et al., 2009). Teaching organizations (NSTA, 2014 and NAEYC, 2009) have given guidelines to support changing this view. By shifting the way science is presented to young children, from memorized facts and figures to learning science practices and the nature of science, science no longer must be too hard, too time consuming nor will the teachers be limited in their resources.

Part of the problem is the lack of access early childhood educators have to classes and trainings that address science education as discussed in the Introduction and seen in Appendix A. This study focused on developing and testing the effectiveness of a training that improves preschool teachers understanding of science practices and the nature of science to improve their self-efficacy in preschool science education. The results from the surveys and the lesson plan work samples show positive growth in the teachers understanding of how Mind in the Making life skills can be incorporated with science practices and the nature of science in their classrooms.

\section{Mind in the Making}

Based on results from the survey questions 1 through 3 and the lesson plans, the teachers left the trainings with a better understanding of Mind in the Making life skills and how it connects to the nature of science and science practices as outlined in Appendix B. Survey responses demonstrated, high percentage (between $89 \%$ and 94\%) 
of the teachers improved their understanding of Mind in the Making skill sets critical thinking (94\%) and problem solving (89\%), as well as their ability to adjust lesson plans to allow for taking on challenges and self-directed, engaged learning (92\%). Added to this, the statistical analysis indicates that the results are significant.

The results of the lesson plan worksheets, as shown in Figure 18, indicate the teachers can integrate science education into Mind in the Making life skills. Across the five "E's" the more teachers were able to effectively connect the Mind in the Making life skills their students were utilizing with science learning. Critical thinking, according to Galinsky (2010), is the process of finding valid information to base beliefs, decisions, and actions on. This connects with the nature of science construct science is a way of knowing (NGSS Lead States, 2013) and the science practice of 6) constructing explanations and solving problems and 8) obtaining, evaluating, and communicating information (NRC, 2012). Problem solving is part of the Mind in the Making skills sets of making connections and taking on challenges. Making connections involves categorizing information and going beyond just knowing information to being able to use it (Galinsky, 2010). Being able to face a challenge and find solutions is the part of problem solving that plans and carries out investigations, instead of just walking away or hiding (Galinsky 2010). All of these skills are developed as part of the development of science investigations.

\section{Self-Efficacy}

One aspect of self-efficacy this training focused on was helping preschool teachers understand they do not need to know all of the answers to children's questions to be effective teaching science. As seen in Figures $7 a-8 b$, the teachers were asked about 
their ability to welcome questions and support their students in finding answers. All four figures show the teachers perceived an increase in their ability to work with children's questions rather than the need to have a ready answer. The activities in the trainings focused on the big ideas of science, the nature of science and hands-on exploration of the natural world. By increasing their comfort level, the teachers indicated, in Figures 9a \& b, that they were willing to try exploring with the children without having all of the answers. These results wupport the conclusions drawn by Wilson (2007) and Brennaman et al. (2009)

For an example, one of the teachers commented that her lesson plan was outside of her comfort zone. She made ramps from the corners of heavy duty shipping boxes and lined them with various materials so the children could learn about how friction changes the speed of rolling objects. In the reflection section of the lesson plan worksheet she stated, “...This has been a very popular activity in our movement room. I would keep this activity the same because it keeps the kids engaged in problem solving and cooperative play for long periods of time... I would love to do this same activity with a larger group of children for longer periods of time..."

\section{Understanding of the Nature of Science and Science Inquiry}

The results show that there was an increase in the perceived understanding the teachers had regarding the nature of science and science inquiry in the preschool classroom. Seventy-six percent of the teachers, shown in Figure 11a, perceive a better understanding that scientific knowledge is open to revision in light of new evidence. Figure $14 \mathrm{a}$ shows that $84 \%$ of the teachers, that were not part of the ceiling effect, indicated a perceived increase in their understanding that scientific investigations use 
various methods. On a personal level, in Figure 13a 79\% of the teachers perceived an increase in their ability to use the nature of science and science practices to understand phenomenon.

The lesson plan work samples also demonstrate the teachers ability to apply the nature of science and science inquiry in practice, not just in theory. Figure 17 indicates that the teachers were able to connect a science practice to instructional techniques in four of the five "E's". Figure 16 indicates that over fifty percent of the teachers were able to connect their lesson plan to a big idea in science. Figure 19 shows how the teachers can apply science concepts to their teaching practices. Sixty percent could describe how their planned science investigation improved science understanding. Of those, five teachers connected their investigation to the nature of science constructs and science practices.

The breadth and depth of the lessons the teachers developed and presented indicate that they have a better understanding of how science education can look with young children. These results support the work of Wilson (2007) and Brennaman et al. (2009).

For example, one of the toddler teachers demonstrated that air is matter by throwing a plastic bag in the air and having the children watch it fall down. Then she filled the bag with air and threw it in the air and watched it float down. This investigation incorporated science practices (developing and using models; and planning and carrying out investigations), Mind in the Making life skills (focus and self-control; making connections; critical thinking; and taking on challenges), and the nature of science constructs (science knowledge is based on empirical evidence; scientific 
investigation use a variety of methods; and science is a way of knowing). Another teacher used the winter storms to demonstrate the phases of water to her preschoolers by repeatedly bringing in ice, letting it melt, and then taking it outside again to freeze. She did the same with boiling water, catching the steam and turning it back into water. Her investigation incorporated science practices (asking questions; planning and carrying out investigations; analyzing and interpreting data; constructing explanations; obtaining, evaluating and communication information), Mind in the Making life skills (focus and self-control; communicating; making connections; critical thinking; taking on challenges; and self-directed, engaged learning), and the nature of science constructs (science addresses questions about the natural world; science knowledge is based on empirical evidence). Galinsky (2010) in her book, Mind in the Making, identifies seven life skills as being essential for children to be successful in school and life. The Next Generation Science Standards nature of science constructs outline eight understanding about what science is (NGSS Lead States, 2013) The Framework (NRC, 2012) lists the science practices that make up an investigation.

\section{Trainings}

This set of trainings was designed to introduce science concepts to early childhood educators in a manner similar to the way they would interact with their students. The goal was to improve the early childhood educators' comfort with science education. Three sites, with different science orientations, were used to allow the teachers exposure to a variety of community resources. The research used from these trainings investigates the question "can a three day training focusing on the nature of science and science practices as they relate to Mind in the Making make a difference in preschool 
teachers' self-efficacy engaging in science education?". The results allow us to propose answers to this question and provide us with avenues to further explore and evaluate this subject matter.

The findings presented in our results support the research done by Carleton, Fitch, and Krockover (2007), Duran and Duran (2005), and the position paper written by NSTA. Data gathered from the survey results and the lesson plans demonstrate the teachers increase in their understanding of leading science education in their classrooms. The Mind in the Making results showed a definite increase in how the teachers perceived their understanding of how science education integrates with development of Mind in the Making Skills. The results surrounding the nature of science and science practices showed a perceived increase in understanding by the teachers as well.

Therefore, this three-day training focusing on the nature of science and science practices as they relate to mind in the making can make a difference in preschool teachers' self-efficacy when engaging in science education.

\section{Limitations and Challenges}

Sample size is a limitation in analyzing the results of this study. Time and location limited the number of participants.

Survey questions 4,5 , and 10 , presented in a negative format proved to be a challenge. The intent was to determine if the subject was just answering to the assumed positive. The results, particularly when linked to the written responses, bring to question the reliability of the responses. This would indicate that negative format questions, while having a purpose, can be confusing, especially for teachers that have English as a second language. 


\section{For future consideration}

Despite the limitations and challenges, the information from this study is valuable. Continuing with this type of training and using it to gather more information regarding how to best encourage preschool teachers to engage in and feel comfortable with science education will be of benefit to our children and our society. The more preschool teachers who are able to be part of this type of training, that addresses the integration of Mind in the Making with understanding of science practices and the nature of science, the more information about their needs and interest we can gather. This will allow for the development of trainings that best meet the needs and interests of preschool teachers from a variety of backgrounds and experiences.

Along with the effectiveness of the trainings, there is other information and recommendations garnered. While the Likert scale is easy to evaluate, having a comments section connected to the question improved the understanding of the teachers responses and perceived development. For future surveys questions regarding the teacher's linguistic and cultural/ethnic background should be added. This would allow the integration of information as to education level, cultural background, and years of experience. Follow-up exploration into what supports a preschool teacher to succeed in implementing science education in their classroom will also help improve the training's effectiveness for other teachers. This might give us a better understanding of how to engage early childhood educators who do not want to learn about science education.

Questions that can be that can be drawn from this research are: Is there a difference in the needs of teachers with different educational backgrounds, not just education levels? How can diversity be increased? What is the best way to support 
ELLs? Why do some teachers take this training and continue to engage in scientific inquiry in their classrooms? How can this training be adapted to other parts of the country?

\section{Conclusion}

The results from the measurement instruments indicate that the teachers perceived a benefit from having taken the Connect to Nature training. The three-day training focusing on the nature of science, science practices and Mind in the Making life skills, according to the results, allowed the teachers to understand more about what science really is and how the nature of science and science practices can be applied to the preschool classroom. The teachers also commented on a perceived increase in their selfefficacy engaging in science education with preschool children.

In the words of one of the teachers in the training,

"This class was called "Connect to Nature" and I assumed it would be about "nature" which in my mind meant "being outside". I love being outside and figured I would learn a few new things to do with preschoolers OUTSIDE.

"In the first couple of minutes, it became clear the class was about SCIENCE, and my initial reaction was OH NO!! I don't like SCIENCE very much and that's going to ruin everything...

"But ultimately, I discovered a new way of looking at "science" in preschool, and realize that pretty much EVERYTHING really IS science, and by labeling it as such, I can acturally create a more fertile ground of exploring \& learning.

"And the forum to share ideas with such intelligent, creative and kind teachers and fellow classmates was most excellent. 
"Thank You."

Student 11a 


\section{Work Cited}

Andersson, K. and Gullburg, A. (2012). What is science in preschool and what do teachers have to know to empower children? Cultural Studies of Science Education 9:2

Bosse, S., Jacobs, G., and Anderson, T. (2009). Science in the Air. Young Children. 64:6, 10-15

Brenneman, K., Stevenson-Boyd, J., and Frede, E. (2009). Math and science in preschool: Policies and practice. National institute for early education research. 19.

Carleton L., Fitch, J., and Krockover G. (2007). An In-Service Teacher Education Program's Effect on Teacher Efficacy and Attitudes. The Educational Forum, $72: 1,46-62$

Conezio, K. and French, L. (2002). Science in the Preschool Classroom: Capitalizing on children's fascination with the everyday world to foster language and literacy development.. Young Children. 57:5, 12-18

Desilver, D. (2017). U.S. students' academic achievement still lags that of their peers in many other countries. Pew Research Center.

Duran, E. and Duran, L. (2005). Project ASTER: A model staff development program and its impact on early childhood teachers' self-efficacy. Journal of elementary science education, 17:2, 1-12

Fantuzzo, J., Perlman, S., Sproul, F., Minney, A., Perry, M. A., and Li, F. (2012). Making visible teacher reports of their teaching experiences: The early childhood teacher experiences scale. Psychology in the schools, 49:2, 194-205.

Galinsky, E. (2010) Mind in the Making: The Seven Essential Life Skills Every Child needs. New York: HarperCollins Publishers.

Head Start (2015). Head start early learning outcomes framework: Ages birth to five. Administration for children \& families.

Keeley, P. (2013). Uncovering Student Ideas in Primary Science, Volume 1: 25 New Formative Assessment Probes for Grades $K-2$. Arlington, VA: NSTA Press.

Maier, M., Greenfield, D., Bulotsky-Shearer, R. (2013). Development and validation of preschool teachers' attitudes and beliefs toward science teaching questionnaire. Early childhood research quarterly. 28:2, 366-378. 
Morgan, P., FarKas, G., Hillemeier, M., and Maczuga, S. (2016). Science achievement gaps begin very early, persist, and are largely explained by modifiable factors. Educational researcher. 45:1, 18-35

National Association for the Education of Young Children (NAEYC) (2009). Developmentally Appropriate Practice in Early Childhood Programs Serving Children from Birth through Age 8.

National Science Teachers Association (NSTA) (2014). NSTA position statement: Early childhood science education.

NGSS Lead States. (2013). Next generation science standards: For states, by states. Washington, DC: The National Academies Press.

Riggs, I., \& Knochs, L. (1990). Towards the development of an elementary teacher's science teaching efficacy belief instrument. Science Education, 74, 625-637.

Shiller, J. and Arena, C. (2012). How Corporations Are Helping To Solve the Education Crisis. Fast Company.

U.S. Bureau of Labor Statistics (2014). Occupational employment, job openings and worker characteristics. (Data file)

U.S. Chamber of Commerce Foundation (2013). Stem education network: A practitioners guide. Washington, DC.

Vermont Agency of Education (2015). Vermont Early Learning Standards.

Walker, D. (2016). Why STEM Education is the New \#1 Corporate Investment. STEM Village.

Wilson,R. (2007). Promoting the development of scientific thinking. Early childhood news. 
Appendix A

Undergraduate Early childhood Programs that offer science education in Oregon

\begin{tabular}{|c|c|c|c|c|c|c|}
\hline School & Arts & $\begin{array}{l}\text { Language/ } \\
\text { Literature }\end{array}$ & Math & $\begin{array}{l}\text { Large } \\
\text { Motor }\end{array}$ & Science & Music \\
\hline Mt Hood* & 2 & 1 & 2 & & & \\
\hline PCC* & & 1 & & & & \\
\hline $\begin{array}{l}\text { Chemeketa Community } \\
\text { College* }\end{array}$ & 1 & 1 & & & & 1 \\
\hline Lane Community College* & 1 & & & & & \\
\hline $\begin{array}{l}\text { Central Oregon Community } \\
\text { College }\end{array}$ & 0.5 & 3 & 0.5 & & 0.5 & 0.5 \\
\hline $\begin{array}{l}\text { Clackamas Community } \\
\text { College* }\end{array}$ & & 1 & 0.5 & & 0.5 & 0.5 \\
\hline Rogue Community College & & 1 & 2 & & & \\
\hline $\begin{array}{l}\text { Southwestern Oregon } \\
\text { Community College }\end{array}$ & 2 & 1 & 1 & & & 1 \\
\hline \multicolumn{7}{|l|}{$\begin{array}{l}\text { Kalamath Community } \\
\text { College* }\end{array}$} \\
\hline PSU Pre-teaching & 1 & 1 & 1 & & & \\
\hline Concordia & 0.5 & 2 & 1 & & 1 & 0.5 \\
\hline Warner Pacific College & 0.5 & 2 & 1 & 1 & 1 & 0.5 \\
\hline University of Oregon & 1 & 2 & & & & \\
\hline Southern Oregon University & & 1 & & & & \\
\hline $\begin{array}{l}\text { Total number of courses } \\
\text { minus electives }\end{array}$ & 9.5 & 17 & 9 & 1 & 3 & 4 \\
\hline
\end{tabular}

Colleges in red do not have a science requirement to get an Associates of Applied Sciences Degree

* Does not offer a Associates of Science tranfer degree 


\section{Appendix B}

Mind in the Making as related to the NOS and Science Practices

\begin{tabular}{|c|c|c|}
\hline Mind in the Making & $\begin{array}{l}\text { Nature of Science } \\
\text { Constructs }\end{array}$ & Science Practices \\
\hline 1. Focus and self-control & & \multirow{2}{*}{$\begin{array}{l}\text { Planning and } \\
\text { carrying out } \\
\text { investigations }\end{array}$} \\
\hline $\begin{array}{l}\text { Children need this skill in order to achieve their } \\
\text { goals, especially in a world that is filled with } \\
\text { distractions and information overload. It involves } \\
\text { paying attention, remembering the rules, thinking } \\
\text { flexibly and exercising self-control. }\end{array}$ & & \\
\hline 2. Perspective taking & & \\
\hline $\begin{array}{l}\text { Perspective goes far beyond empathy: it involves } \\
\text { figuring out what others think and feel, and forms } \\
\text { the basis of children understanding their parents', } \\
\text { teachers' and friends' intentions. Children who } \\
\text { can take others' perspectives are also much } \\
\text { less likely to get involved in conflicts. }\end{array}$ & & \\
\hline 3. Communicating & \multirow{2}{*}{$\begin{array}{l}\text { Science addresses } \\
\text { questions about the natural } \\
\text { and material world }\end{array}$} & \multirow{2}{*}{$\begin{array}{l}\text { Asking questions; } \\
\text { Constructing } \\
\text { explanations; } \\
\text { Obtaining, evaluating } \\
\text { and communicating } \\
\text { information }\end{array}$} \\
\hline $\begin{array}{l}\text { Communicating is much more than understanding } \\
\text { language, speaking, reading and writing - it is the } \\
\text { skill of determining what one wants to } \\
\text { communicate and realizing how our } \\
\text { communications will be understood by others. It } \\
\text { is the skill that teachers and employers feel is } \\
\text { most lacking today. }\end{array}$ & & \\
\hline 4. Making connections & \multirow[b]{2}{*}{$\begin{array}{l}\text { Scientific models, laws, } \\
\text { mechanisms, and theories } \\
\text { explain natural } \\
\text { phenomena; Scientific } \\
\text { knowledge assumes an } \\
\text { order and consistency in } \\
\text { natural systems; Science } \\
\text { addresses questions about } \\
\text { the natural and material } \\
\text { world }\end{array}$} & \multirow[b]{2}{*}{$\begin{array}{l}\text { Developing and using } \\
\text { models; Analyzing } \\
\text { and interpreting data; } \\
\text { Obtaining, evaluating } \\
\text { and communicating } \\
\text { information }\end{array}$} \\
\hline $\begin{array}{l}\text { Making connections is at the heart of learning- } \\
\text { figuring out what's the same, what's different and } \\
\text { sorting these things into categories. Making } \\
\text { unusual connections is at the core of creativity. In } \\
\text { a world where people can google for information, } \\
\text { it is the people who can see the connections who } \\
\text { can go beyond knowing information to using } \\
\text { this information well. }\end{array}$ & & \\
\hline 5. Critical thinking & \multirow[b]{2}{*}{$\begin{array}{l}\text { Scientific knowledge is } \\
\text { open to revision in light of } \\
\text { new evidence; Science is a } \\
\text { way of knowing; Science } \\
\text { addresses questions about } \\
\text { the natural and material } \\
\text { world }\end{array}$} & \multirow[b]{2}{*}{$\begin{array}{l}\text { Planning and } \\
\text { carrying out } \\
\text { investigations; } \\
\text { Analyzing and } \\
\text { interpreting data; } \\
\text { Obtaining, evaluating } \\
\text { and communicating } \\
\text { information }\end{array}$} \\
\hline $\begin{array}{l}\text { Critical thinking is the ongoing search for valid } \\
\text { and reliable knowledge to guide beliefs, decisions } \\
\text { and actions. }\end{array}$ & & \\
\hline 6. Taking on challenges & & \multirow{2}{*}{$\begin{array}{l}\text { Planning and } \\
\text { carrying out } \\
\text { investigations }\end{array}$} \\
\hline $\begin{array}{l}\text { Life is full of stresses and challenges. Children } \\
\text { who are willing to take on challenges (instead of } \\
\text { avoiding them or simply coping with them) do } \\
\text { better in school and in life. }\end{array}$ & & \\
\hline 7. Self-directed engaged learning & \multirow{2}{*}{$\begin{array}{l}\text { Scientific knowledge is } \\
\text { open to revision in light of } \\
\text { new evidence; Science is a } \\
\text { way of knowing }\end{array}$} & \multirow{2}{*}{$\begin{array}{l}\text { Planning and } \\
\text { carrying out } \\
\text { investigations }\end{array}$} \\
\hline $\begin{array}{l}\text { It is through learning that we can realize our } \\
\text { potential. As the world changes, so can we, for as } \\
\text { long as we live - as long as we learn. }\end{array}$ & & \\
\hline
\end{tabular}




\section{Appendix C}

Work Sample Requirements:

Lesson Plan Title:

Topic:

What is the Essential Question you are building an answer to?

What is the big idea you want your students to take away from the lesson?

Learning goal:

When my students do to $?$ they will be able

\begin{tabular}{|l|l|l|}
\hline \multicolumn{1}{|c|}{ Activity } & $\begin{array}{l}\text { Science } \\
\text { Practice }\end{array}$ & $\begin{array}{c}\text { Mind in the } \\
\text { Making Life } \\
\text { Skills }\end{array}$ \\
\hline Engage: & & \\
$\begin{array}{l}\text { What question will you answer or problem } \\
\text { will you solve? }\end{array}$ & & \\
\hline $\begin{array}{l}\text { Explore: } \\
\text { How will you gather evidence or "data" to } \\
\text { help answer your question? }\end{array}$ & & \\
\hline $\begin{array}{l}\text { Explain: } \\
\text { How will you answer the question using } \\
\text { evidence from your explorations? }\end{array}$ & & \\
\hline
\end{tabular}




\begin{tabular}{|l|l|l|}
\hline Elaborate: & & \\
$\begin{array}{l}\text { How will you expand your understanding } \\
\text { into a new experience? }\end{array}$ & & \\
\hline $\begin{array}{l}\text { Evaluate: } \\
\text { How will you help your students assess } \\
\text { know they have learned? How will you } \\
\text { essential question? }\end{array}$ & & \\
\hline
\end{tabular}

How will this activity help your students understand what science is?

Reflection:

How do you know you met your learning goal?

What would you keep the same? Why?

What would you do differently? Why?

What would you do to make this lesson more effective? 
Work Sample Requirements:






\begin{tabular}{|c|c|c|}
\hline $\begin{array}{l}\text { How will you answer the } \\
\text { question using evidence } \\
\text { from your explorations? }\end{array}$ & $\begin{array}{l}\text { Rubric: } \\
\text { 1) No answer or an } \\
\text { unrelated answer } \\
\text { 2) An answer that matches } \\
\text { the aspect of the lesson } \\
\text { plan that was being } \\
\text { addressed }\end{array}$ & $\begin{array}{l}\text { Rubric: } \\
\text { 1) No answer or an } \\
\text { unrelated answer } \\
\text { 2) An answer that matches } \\
\text { the aspect of the lesson } \\
\text { plan that was being } \\
\text { addressed }\end{array}$ \\
\hline $\begin{array}{l}\text { How will you expand your } \\
\text { understanding into a new } \\
\text { experience? }\end{array}$ & $\begin{array}{l}\text { Rubric: } \\
\text { 1) No answer or an } \\
\text { unrelated answer } \\
\text { 2) An answer that matches } \\
\text { the aspect of the lesson } \\
\text { plan that was being } \\
\text { addressed }\end{array}$ & $\begin{array}{l}\text { Rubric: } \\
\text { 1) No answer or an } \\
\text { unrelated answer } \\
\text { 2) An answer that matches } \\
\text { the aspect of the lesson } \\
\text { plan that was being } \\
\text { addressed }\end{array}$ \\
\hline $\begin{array}{l}\text { How will you help your } \\
\text { students assess what they } \\
\text { have learned? How will } \\
\text { you know they are building } \\
\text { an answer to the essential } \\
\text { question? }\end{array}$ & $\begin{array}{l}\text { Rubric: } \\
\text { 1) No answer or an } \\
\text { unrelated answer } \\
\text { 2) An answer that matches } \\
\text { the aspect of the lesson } \\
\text { plan that was being } \\
\text { addressed }\end{array}$ & $\begin{array}{l}\text { Rubric: } \\
\text { 1) No answer or an } \\
\text { unrelated answer } \\
\text { 2) An answer that matches } \\
\text { the aspect of the lesson } \\
\text { plan that was being } \\
\text { addressed }\end{array}$ \\
\hline \multicolumn{2}{|c|}{$\begin{array}{l}\text { How will this activity help your students } \\
\text { understand what science is? }\end{array}$} & $\begin{array}{l}\text { Rubric: } \\
\text { 1) An answer } \\
\text { 2) An answer about the } \\
\text { conclusions the experiment } \\
\text { made } \\
\text { 3) The activity is connect } \\
\text { to the nature of science and } \\
\text { science practices that were } \\
\text { used in the activity }\end{array}$ \\
\hline \multicolumn{3}{|c|}{$\begin{array}{l}\text { Reflection: } \\
\text { How do you know you met your learning goal? }\end{array}$} \\
\hline \multicolumn{3}{|c|}{ What would you keep the same? Why? } \\
\hline \multicolumn{3}{|c|}{ What would you do differently? Why? } \\
\hline What would you do to make & this lesson more effective? & \\
\hline
\end{tabular}




\section{Appendix E \\ PRESCHOOL EDUCATORS' UNDERSTANDING REGARDING THE NATURE OF SCIENCE AND SCIENCE INQUIRY}

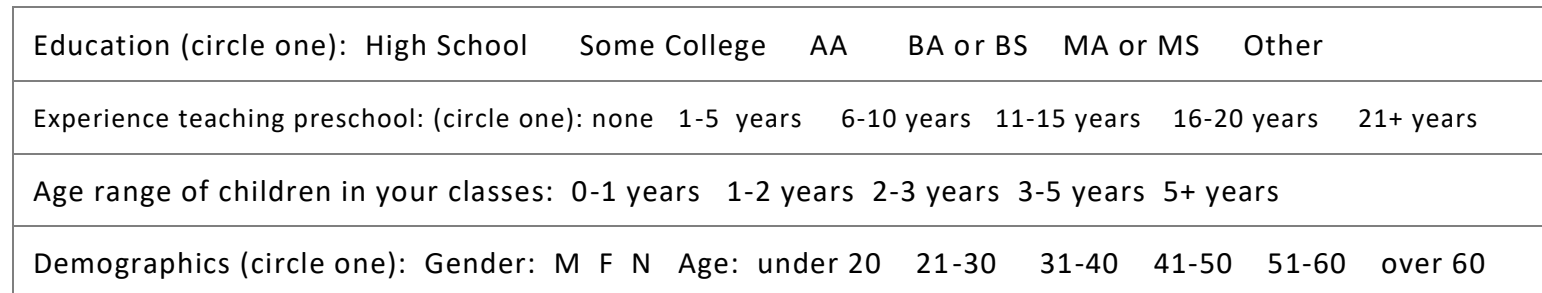

For each item identified below, circle the number to the right that best fits your agreement with the statement.

Use the rating scale to select the quality number.

\begin{tabular}{|c|c|c|c|c|c|}
\hline \multirow[b]{2}{*}{ Survey Item } & \multicolumn{5}{|c|}{ Scale } \\
\hline & $\begin{array}{l}\overrightarrow{0} \\
0 \\
0 \\
0 \\
0 \\
0\end{array}$ & $\begin{array}{l}Z \\
\stackrel{Z}{0} \\
\stackrel{0}{0} \\
\stackrel{\theta}{\varrho}\end{array}$ & $\begin{array}{l}\underset{D}{2} \\
\frac{2}{2}\end{array}$ & 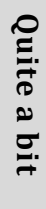 & 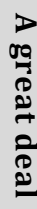 \\
\hline \multirow{2}{*}{$\begin{array}{l}\text { 1. I believe science inquiry promotes critical thinking in } \\
\text { students. }\end{array}$} & Pre & 1 & 2 & 3 & 4 \\
\hline & Post & 1 & 2 & 3 & 4 \\
\hline
\end{tabular}

Explain more:

I believe the nature of science includes student problem solving.

\begin{tabular}{|c|c|c|c|c|}
\hline Pre & 1 & 2 & 3 & 4 \\
\hline Post & 1 & 2 & 3 & 4 \\
\hline
\end{tabular}

Explain more:

3. I can adjust my lessons to the appropriate level for individual students.

\begin{tabular}{|c|c|c|c|c|}
\hline Pre & 1 & 2 & 3 & 4 \\
\hline Post & 1 & 2 & 3 & 4 \\
\hline
\end{tabular}

Explain more:

4. Even when I try very hard, I don't teach science as well as I do most other subjects.

\begin{tabular}{|c|c|c|c|c|}
\hline Pre & 1 & 2 & 3 & 4 \\
\hline Post & 1 & 2 & 3 & 4 \\
\hline
\end{tabular}

Explain more: 


\begin{tabular}{|c|c|c|c|c|c|}
\hline \multirow{2}{*}{$\begin{array}{l}\text { 5. I am not very effective in teaching/leading hands-on } \\
\text { science projects }\end{array}$} & Pre & 1 & 2 & 3 & 4 \\
\hline & Post & 1 & 2 & 3 & 4 \\
\hline \multicolumn{6}{|l|}{ Explain more: } \\
\hline \multirow{2}{*}{$\begin{array}{l}\text { 6. I understand science concepts well enough to be effective } \\
\text { in teaching science. }\end{array}$} & Pre & 1 & 2 & 3 & 4 \\
\hline & Post & 1 & 2 & 3 & 4 \\
\hline \multicolumn{6}{|l|}{ Explain more: } \\
\hline \multirow{2}{*}{$\begin{array}{l}\text { 7. I am typically able to help students answer their own } \\
\text { questions in science. }\end{array}$} & Pre & 1 & 2 & 3 & 4 \\
\hline & Post & 1 & 2 & 3 & 4 \\
\hline \multicolumn{6}{|l|}{ Explain more: } \\
\hline \multirow{2}{*}{$\begin{array}{l}\text { 8. I have the necessary skills to teach hands-on/inquiry-based } \\
\text { science. }\end{array}$} & Pre & 1 & 2 & 3 & 4 \\
\hline & Post & 1 & 2 & 3 & 4 \\
\hline \multicolumn{6}{|l|}{ Explain more: } \\
\hline \multirow{2}{*}{ 9. When teaching science, I welcome student questions. } & Pre & 1 & 2 & 3 & 4 \\
\hline & Post & 1 & 2 & 3 & 4 \\
\hline \multicolumn{6}{|l|}{ Explain more: } \\
\hline \multirow{2}{*}{$\begin{array}{l}\text { 10. I believe all students should get the same results when } \\
\text { conducting a scientific experiment. }\end{array}$} & Pre & 1 & 2 & 3 & 4 \\
\hline & Post & 1 & 2 & 3 & 4 \\
\hline \multicolumn{6}{|l|}{ Explain more: } \\
\hline
\end{tabular}




\begin{tabular}{|c|c|c|c|c|c|}
\hline \multirow{2}{*}{$\begin{array}{l}\text { 11. I believe scientific theories can change based on new } \\
\text { evidence. }\end{array}$} & Pre & 1 & 2 & 3 & 4 \\
\hline & Post & 1 & 2 & 3 & 4 \\
\hline \multicolumn{6}{|l|}{ Explain more: } \\
\hline \multirow{2}{*}{ 12. I believe it is my job to foster student problem solving. } & Pre & 1 & 2 & 3 & 4 \\
\hline & Post & 1 & 2 & 3 & 4 \\
\hline \multicolumn{6}{|l|}{ Explain more: } \\
\hline \multirow{2}{*}{$\begin{array}{l}\text { 13. When I encounter a new phenomenon, I know how to use } \\
\text { the nature of science and science inquiry as tools to } \\
\text { understand the phenomenon. }\end{array}$} & Pre & 1 & 2 & 3 & 4 \\
\hline & Post & 1 & 2 & 3 & 4 \\
\hline \multicolumn{6}{|l|}{ Explain more: } \\
\hline \multirow{2}{*}{ 14. I can use simple everyday items to teach science. } & Pre & 1 & 2 & 3 & 4 \\
\hline & Post & 1 & 2 & 3 & 4 \\
\hline \multicolumn{6}{|l|}{ Explain more: } \\
\hline \multirow{2}{*}{ 15. I believe there is only one best way to teach science. } & Pre & 1 & 2 & 3 & 4 \\
\hline & Post & 1 & 2 & 3 & 4 \\
\hline \multicolumn{6}{|l|}{ Explain more: } \\
\hline
\end{tabular}




\section{Appendix F}

\section{PRESCHOOL EDUCATORS' UNDERSTANDING REGARDING THE NATURE OF SCIENCE AND SCIENCE INQUIRY (RUBRIC)}

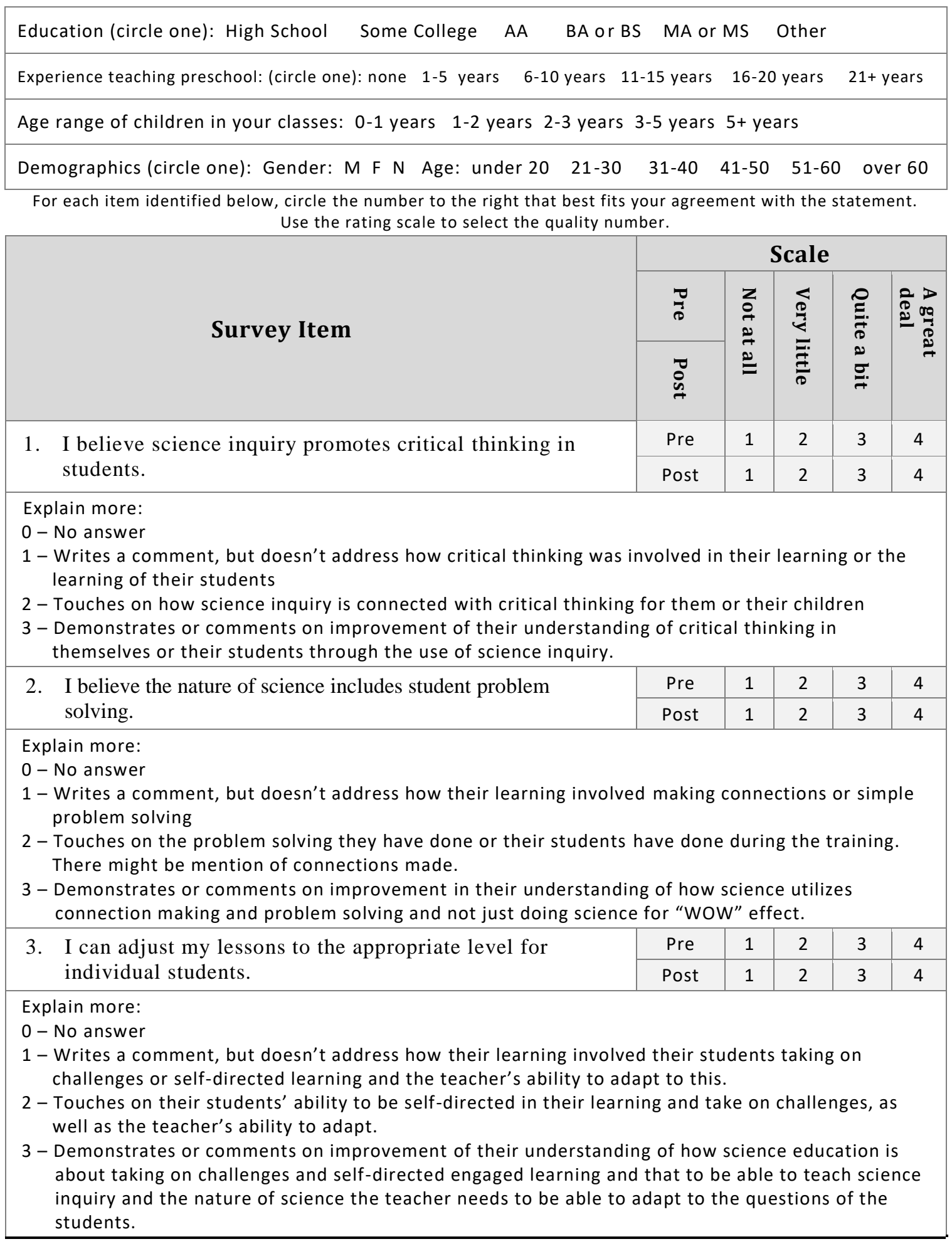




\begin{tabular}{|c|c|c|c|c|c|}
\hline \multirow{2}{*}{$\begin{array}{l}\text { 4. Even when I try very hard, I don't teach science as well } \\
\text { as I do most other subjects. }\end{array}$} & Pre & 1 & 2 & 3 & 4 \\
\hline & Post & 1 & 2 & 3 & 4 \\
\hline \multicolumn{6}{|c|}{$\begin{array}{l}\text { Explain more: } \\
0 \text { - No answer } \\
1 \text { - Writes a comment, but doesn't mention any growth in their ability to teach science } \\
2 \text { - Mentions how they might improve their ability to teach science. } \\
3 \text { - Describes how they have changed their view of teaching science and/or how they have } \\
\text { implemented the changes. }\end{array}$} \\
\hline \multirow{2}{*}{$\begin{array}{l}\text { 5. I am not very effective in teaching/leading hands-on } \\
\text { science projects }\end{array}$} & Pre & 1 & 2 & 3 & 4 \\
\hline & Post & 1 & 2 & 3 & 4 \\
\hline
\end{tabular}

\section{Explain more:}

0 - No answer

1 - Writes a comment, but doesn't address how they use hands-on science projects

2 - Mentions how they plan on using hands-on science projects.

3 - Describes how they have used hands-on science projects and will continue to use them in the future.

6. I understand science concepts well enough to be effective in teaching science.

\begin{tabular}{|c|l|l|l|l|}
\hline Pre & 1 & 2 & 3 & 4 \\
\hline Post & 1 & 2 & 3 & 4 \\
\hline
\end{tabular}

Explain more:

$0-$ No answer

1 - Writes a comment, but doesn't feel they understand science concepts.

2 - Mentions wanting to use science more in the classroom, but still feels the need to know more facts and tricks.

3 - Describes how they have become more comfortable not knowing the answer but being able to find the answers with the children.

7. I am typically able to help students answer their own questions in science.

\begin{tabular}{|c|c|c|c|c|}
\hline Pre & 1 & 2 & 3 & 4 \\
\hline Post & 1 & 2 & 3 & 4 \\
\hline
\end{tabular}

Explain more:

$0-$ No answer

1 - Writes a comment, but doesn't address how they help students answer their own questions in science.

2 - Mentions how they plan to do more research to present better facts to answer their students' questions.

3 - Describes how they use science inquiry to work with their students to find the answers to the children's questions.

8. I have the necessary skills to teach hands-on/inquirybased science.

\begin{tabular}{|c|c|c|c|c|}
\hline Pre & 1 & 2 & 3 & 4 \\
\hline Post & 1 & 2 & 3 & 4 \\
\hline
\end{tabular}

Explain more:

$0-$ No answer

1 - Writes a comment, but still comments on not being able to teacher science inquiry well

2 - Discusses their attempt at teaching science inquiry.

3 - Describes the skills they have developed to teach hands-on/inquiry-based science.

9. When teaching science, I welcome student questions.

\begin{tabular}{|c|l|l|l|l|}
\hline Pre & 1 & 2 & 3 & 4 \\
\hline Post & 1 & 2 & 3 & 4 \\
\hline
\end{tabular}

Explain more:

$0-$ No answer

1 - Writes a comment, but still wants to be "The Sage on the Stage"

2 - Touches on wanting to feel comfortable with students' questions

3 - Describes how they work with students' questions. 


\begin{tabular}{|c|c|c|c|c|c|}
\hline \multirow{2}{*}{$\begin{array}{l}\text { 10. I believe all students should get the same results when } \\
\text { conducting a scientific experiment. }\end{array}$} & Pre & 1 & 2 & 3 & 4 \\
\hline & Post & 1 & 2 & 3 & 4 \\
\hline \multicolumn{6}{|c|}{$\begin{array}{l}\text { Explain more: } \\
0 \text { - No answer } \\
1 \text { - Writes a comment, but doesn't address science as either a body of knowledge and a process or the } \\
\text { need for creativity and imagination } \\
2 \text { - Touches on either science as a body of knowledge and a process or the creative aspect of science } \\
\text { that brings about different answers. } \\
3 \text { - Demonstrates that they understand how creativity and imagination produce a scientific way of } \\
\text { knowing how the world works. }\end{array}$} \\
\hline \multirow{2}{*}{$\begin{array}{l}\text { 11. I believe scientific theories can change based on new } \\
\text { evidence. }\end{array}$} & Pre & 1 & 2 & 3 & 4 \\
\hline & Post & 1 & 2 & 3 & 4 \\
\hline \multicolumn{6}{|c|}{$\begin{array}{l}\text { Explain more: } \\
0 \text { - No answer } \\
1 \text { - Writes a comment, but understand that scientific knowledge is changeable } \\
2 \text { - Know that scientific knowledge is a body of knowledge and a process, but can't translate that into } \\
\text { how children learn about the world. } \\
3 \text { - Understands that young children and professional scientists can both come up with new evidence } \\
\text { or unexpected results. }\end{array}$} \\
\hline \multirow{2}{*}{ 12. I believe it is my job to foster student problem solving. } & Pre & 1 & 2 & 3 & 4 \\
\hline & Post & 1 & 2 & 3 & 4 \\
\hline \multicolumn{6}{|c|}{$\begin{array}{l}\text { Explain more: } \\
0 \text { - No answer } \\
1 \text { - Writes a comment, but is still hesitant about the number and level of children's questions. } \\
2 \text { - Touches on their philosophy about letting children ask questions but wants to still be the source of } \\
\text { all of the children's answers. } \\
3 \text { - Describes how they have fostered student questions and scaffolded the children in finding their } \\
\text { own answers through team work and brainstorming. }\end{array}$} \\
\hline \multirow{2}{*}{$\begin{array}{l}\text { 13. When I encounter a new phenomenon, I know how to use } \\
\text { the nature of science and science inquiry as tools to } \\
\text { understand the phenomenon. }\end{array}$} & Pre & 1 & 2 & 3 & \\
\hline & Post & 1 & 2 & 3 & \\
\hline \multicolumn{6}{|c|}{$\begin{array}{l}\text { Explain more: } \\
0 \text { - No answer } \\
1 \text { - Writes a comment, but doesn't show understanding of the nature of science } \\
2 \text { - Shows an understanding of the patterns that are in the natural world, but not about how they } \\
\text { affect the children's everyday world. } \\
3 \text { - The teacher can use everyday examples for science inquiry and to explore the nature of science. }\end{array}$} \\
\hline
\end{tabular}




\begin{tabular}{|c|c|c|c|c|c|}
\hline \multirow{2}{*}{ 14. I can use simple everyday items to teach science. } & Pre & 1 & 2 & 3 & 4 \\
\hline & Post & 1 & 2 & 3 & 4 \\
\hline \multicolumn{6}{|c|}{$\begin{array}{l}\text { Explain more: } \\
0 \text { - No answer } \\
1 \text { - Writes a comment, but still feels that they need specialized equipment to teach science. } \\
2 \text { - Shows some understanding of how science affects everyday life, but feels that science concepts } \\
\text { can only be taught with specialized equipment and knowledge. } \\
3 \text { - Demonstrates that they were able to lead a science inquiry with the materials they had on hand. }\end{array}$} \\
\hline \multirow{2}{*}{ 15. I believe there is only one best way to teach science. } & Pre & 1 & 2 & 3 & 4 \\
\hline & Post & 1 & 2 & 3 & 4 \\
\hline \multicolumn{6}{|c|}{$\begin{array}{l}\text { Explain more: } \\
0 \text { - No answer } \\
1 \text { - Writes a comment, but still hold to the idea that science is about facts and right and wrong } \\
\text { answers. } \\
2 \text { - Describes being comfortable with the children's misconceptions, but still wants to give them the } \\
\text { right answer. } \\
3 \text { - Accepts the children's misconceptions and helps to lead them to find ways to prove or } \\
\text { disprove their ideas. }\end{array}$} \\
\hline
\end{tabular}

